No. 62

\title{
LONDON BOTANIC GARDENS
}

B Y

PIERRE ÉLIE FÉLIX PERRÉDĖS, B.SC., F.L.S.

Pharmaceutical Chemist, Corresponding Member of The Philadelphia College of Pharmacy

THE WELLCOME CHEMICAL RESEARCH LABORATORIES

FREDERICK B. POWER, PH.D, Director

6 King Street, Snow Hill

ELLCOME COLL.

LONDON, E. C.

/ 336 



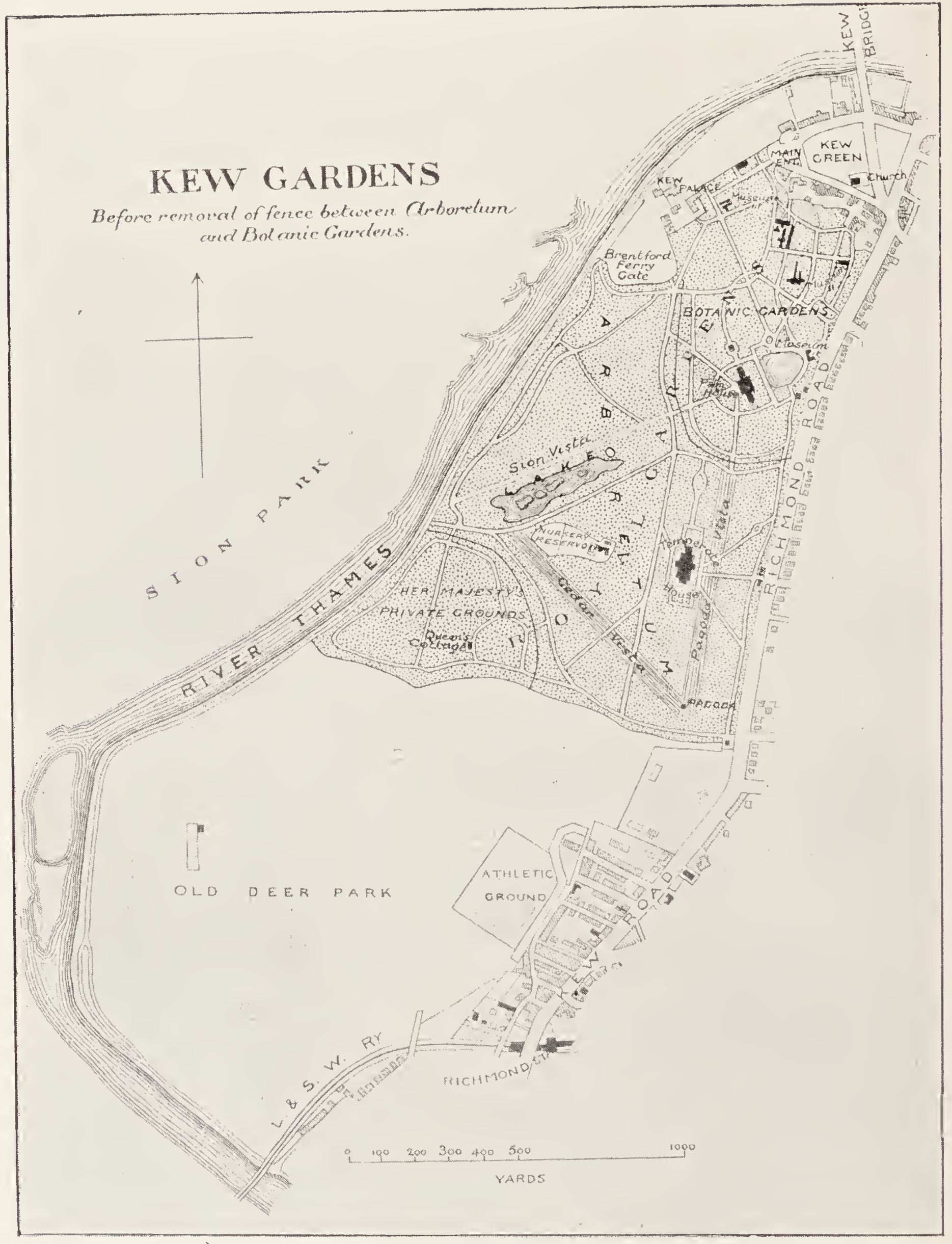

PLAN OF KEW GARDENS AND IMMEDIATE SURROUNDINGS, IN 1895. NOTE. - The dotted area represents the gardens themselves. 


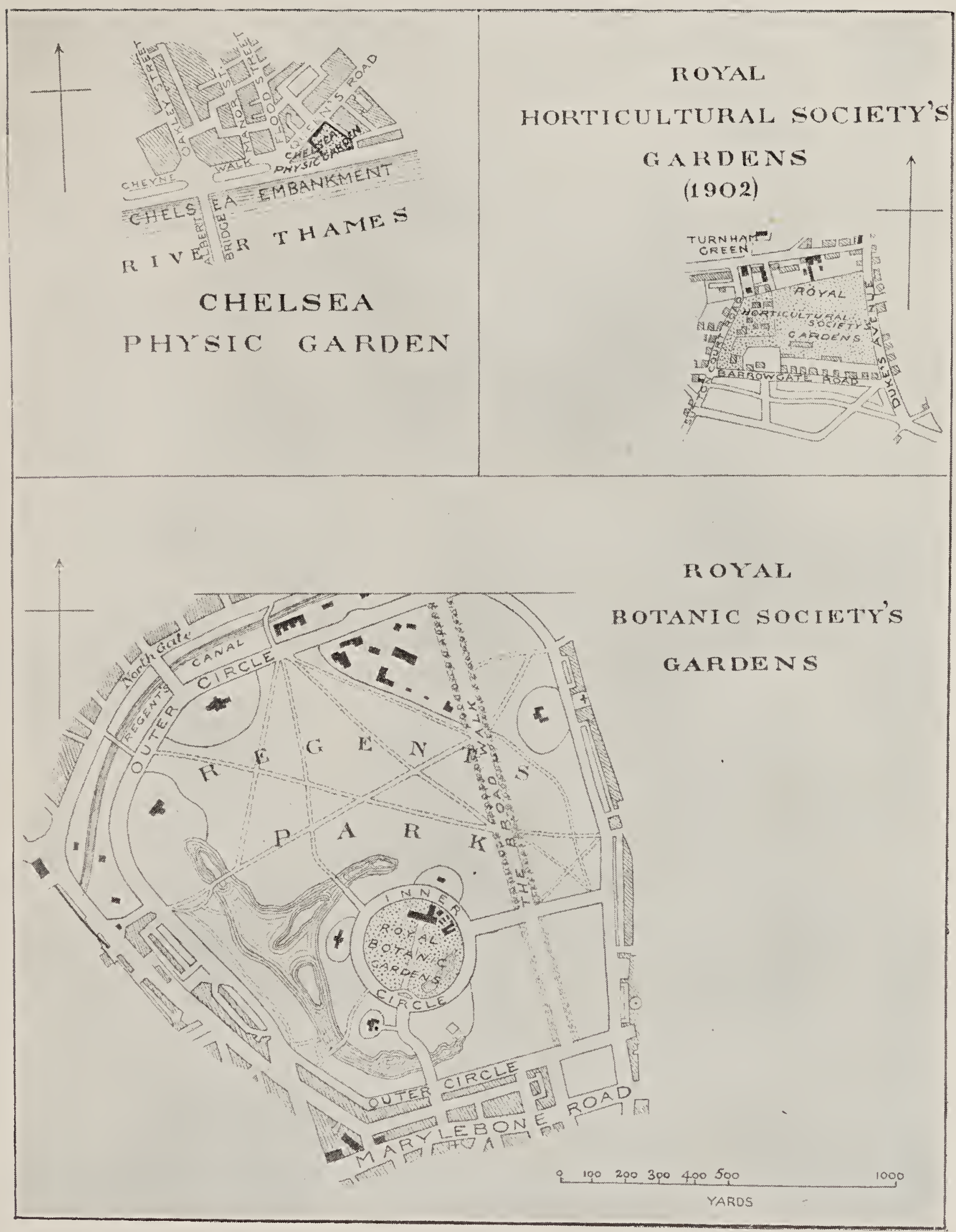

The Chelsea Physic Garden, the ROYal BOtanic SOCIETY's Gardens, and the FORMER GARDENS of the HORTICULTURAL SOCIETY at Chiswick, and their environs, on the SAME SCALE as Kew Gardens in Plate I. 
Digitized by the Internet Archive in 2017 with funding from Wellcome Library

https://archive.org/details/b29007975 


\section{LONDON BOTANIC GARDENS}

BY

PIERRE Élie FÉLIX PERRÉdèS, B.Sc., F.L.S。

Pharmaceutical Chemist, Corresponding Member of

The Philadelphia College of Pharmacy

$\infty \diamond \propto$

The WellCome Chemical Research Laboratories

FREDERICK B. POWER, PH.D., Director

6, King Street, Snow Hill

LONDON, E.C. 
Welcome Litrary for the History and Understanding of Medicine

\section{WELLCOME} COLLECTION

$$
1336
$$




\section{PREFACE}

The series of papers here brought together originally appeared in the American Journal of Pharmacy, having been contributed to that publication at the request of its editor, Professor Henry Kraemer.

In the second, third, and fourth chapters the gardens are considered mainly in their pharmaceutical aspects, so that the Chelsea Physic Garden, to which the fourth chapter is devoted, has received the largest share of attention. In the introductory chapter, on the other hand, an attempt has been made to present such a general view of the London Botanic Gardens as will enable the reader to obtain some idea of their relative importance.

The publication of these papers began in October, I905, and was concluded in August, 1906, but the history of the gardens has not been considered beyond the end of the year 1905. It is of interest to record that since then the publication of the "Kew Bulletin" has been resumed, and that the series of annual volumes has been made continuous by the issue of one or more numbers, with title and table of contents, for each year from I900 to 1905 inclusive.

For valuable assistance received in the preparation of this work, I take the opportunity here afforded of recording my indebtedness and thanks to the following: Mr. H. Howard Batten, Clerk to the Trustees of the Chelsea Physic Garden; Sir William Turner ThiseltonDyer, K.C.M.G., F.R.S., ex-Director of the Royal Gardens at Kew ; ${ }^{1}$ Mr. W. Hales, Curator of the Chelsea Physic Garden; Mr. E. F. Hawes, Chief Instructor of the Practical Gardening School in the Royal Botanic Society's Gardens; Mr. J. M. Hillier, Keeper, and Mr. J. H. Holland, F.L.S., Assistant Keeper, of the Museums of Economic Botany at Kew; Mr. E. M. Holmes, F.L.S., Curator of the Pharmaceutical Society's Museums; Mr. B. Daydon Jackson, F.L S., General Secretary to the Linnean Society of London; Mr.

${ }^{1}$ Sir William Dyer retired from the post of Director on December I5, I905, and Lieut.-Colonel David Prain, I.M.S., F.R.S., then Director of the Botanical Survey of India, was appointed as his successor. 
A. W. Kappel, F.L.S., and Mr. J. W. Knapman, Librarians respectively of the Linnean Society of London and of the Pharmaceutical Society of Great Britain; Mrs. P. E. F. Perrédès; Dr. F. B. Power, Director of the Wellcome Chemical Research Laboratories; Mr. T. E. Sedgwick, Assistant Secretary to the Royal Horticultural Society; Mr. J. B. Sowerby, F.L.S., Secretary to the Royal Botanic Society; and Mr. W. Watson, A.L.S, Curator, Royal Gardens, Kew.

The illustrations, with the exception of Plate XXV, have been prepared expressiy for this work. For their excellence I am chiefly indebted to Mr. Henry S. Wellcome and to the Photographic staff of Messrs. Burroughs, Wellcome \& Co. Plate XXV was printed from a block kindly lent by Mr. Howard Batten; the other plans I have drawn myself.

\section{P. E. F. P.}

THE WEI. COME RESEARCH LABORATORIES,

LoNDON, September, Igo6.

Note.--During the printing of the following pages my attention was kindly directed by Mr. James Britten, F.L.S., of the British MIuseun, to some statements contained in the text which require nodification or anplification. Mr. Britten has been good enough to read through the whole of series of articles, and I here take the opportunity of utilizing his valnable observations and of tendering him $m y$ best thanks.

The statement. on p. Ij, that "The herbarinn1 of Sir Joseph Banks, his scientific library, and the collection of Baner's drawings, had all been transferred to the British. MIusenm after his death, " requires the following slight extension: Banks' herbarium and library, which never were at Kew, were transferred from his private house in Soho Square to the Britisl MIusenn, and Bauer's drawings, which had been kept in the private lonse of the latter at Kew, were likewise renlored to the British Musenn. (For further details, see "History of the Collections in the Natural History Department of the British MIuseun," Vol. I., p. 79, Iondon, I904).

The specinens of plants which were delivered annually to the Royal Society by the Society of Apothecaries (see p. 57) are in the herbarium of the British Musem, and extend to over 3000 .

With regard to Dale's herbariun1 (p. 64), MIr. Brittenl says: "It seems doubtful whether Dale had all Ray's plants. Ray's European herbarium is at South Kensington, but not his British herbarinm." 


\section{CONTENTS.}

PAGE,

r. INTRODUCTORY . . . . . . . . . . . . . . . I

The Royal, Horticultural, Societiy's Gardens . . . . . I5

II. KEW GARDENS . . . . . . . . . . . . . . . . . \7

RICHMOND GARDENS . . . . . . . . . . . . . I7

Kew House AND ITS GROUNDS . . . . . . . . . . I8

Keiw Gardens and Plefasure Grounds. . . . . . . 20

THE EXTENSION OF THE GARDENS . . . . . . . . . 22

The Plant Houses . . . . . . . . . . . . 28

The Museums, Laboratory, and Herbarium . . . . . 32

THE ADMINISTRATION OF KEW AND ITS WORK . . . . . 34

III 'THE ROYAL BOTANIC SOCIETY'S GARDENS, REGENT'S PARK . . . . . . . . . . . . . . 40

THE WORKING OF THE GARDENS . . . . . . . . 46

IV. THE CHELSEA PHYSIC GARDEN . . . . . . . . . . 48

THE WORK ACCOMPLISHED IN THE GARDEN DURING THE ADMINISTRATION OF THE SOCIETY OF APOTHECARIES . . 7 I

The Chelsea Physic Garden Under the Present AdminISTRATION . . . . . . . . . . . . . 89 



\section{LIST OF PLATES}

PIATE I。

PLATE II.

PLATE III.

PIATE IV.

PLATE V.

PrATE VI.

PIATE VII.

PIATE VIII.

PIATE IX.

PIATE $\mathrm{X}$.

PIATE XI.

PIATE XII.

PIATE XIII.

PIATE XIV.

PLATE XV.

PIATE XVI.

PLATE XVII.

PrATE XVIII.

PLATE XIX.

PLATE XX.

$\mathrm{PIATE}_{\text {A }} \mathrm{XXI}$.

PLATE XXII.

PIATE XXIII.

PLATE XXIV.

PLATE XXV.

PLATE XXVI.

PIATE XXVII.

PIATE XXVIII. HY

PLATE XXIX.

PIATE XXX. PIATE XXXI.
PIAN OF KEW GARDENS AND IMIMEDIATE SURROUNDIIJGS, IN $\mathrm{I} 895$. . . . . . . . . . Facing Title-page

THE CHELSEA PHYSIC GARDEN, THE ROyal BOTANIC SOCIETY'S GARDENS, AND THE FORMER GARDENS OF THE, HORTICULURAI, SOCIETY AT CHISWICK, AND THEIR ENVIRONS, ON THE SAME SCALE AS KFW GARDENS IN Plate I. . . . . . . . . . Facing Title-page

HERBACEOUS GROUND, KEW GARDENS. . . . . . 2 Herbacelous Ground, ROyal, BOTANIC SOCIETY'S GARDENS, REGENT'S PARK . . . . . . . . PIANT HOUSE, OID STYLE-THE ORANGERY (NOW Museiun III.) a T $\mathrm{KeW}$. . . . . . . . . . . . . 4

Plan'T HOUSE, NEW STYLE-THE, PALM HOUSE, KËW 5 LABORATORY, LECTURE: HAII, AND CURATOR'S RESIDENCE, CHEISFA PHYSIC GARDEN . . . 8

MIUSEUM I., AT KEW . . . . . . . . . . . . I4

Main Entrance to KelW Gardens ...... I7

PORTION OF KEW GARDENS KNOWN AS THE "BOTANIC GARDENS" PROPER . . . . . . . . . 22

THE LAKE IN THE ARBORFTUM, KEW GARDENS • . 24 INTERIOR OF SUCCUIANT HOUSE, KEW GARDENS . 28 Temperate House, Kew Gardens. . . . . . 30 INTERIOR OF T'EMPERATE HOUSE (CENTRAL BLOCK), KEIW GARDENS ............ . . $3 \mathrm{I}$

Heirbariun and Iibrary, KeW Gardens . . . . 32 MAIN ENTRANCE TO THE ROYAL BOTANIC SOCIETY'S GARDENS, REGENT'S PARK . . . . . . 40

PLAN OF THE ROYAL BOTANIC SOCIETY'S GARDENS 42 THE LAKE IN THE ROyal, Bo'TANIC SOCIETY'S GARDENS 43 GENTIANA LUTEA, L., GROWING IN THE ROYAL, BOTANIC SOCIETY'S GARDENS ....... 44

VERATRUII VIRIDE, Soland., GROWING IN THE Royal, Botanic SOcietry's GaRdens . . . . 45

SECRETARY'S HoUse AND MUSEUM, ROYAL Bo'TANiC SOCIETY'S GARDENS . . . . . . . . . 46 STUDENTS' ENTRANCE TO THE CHEISEA PHYSIC GARDEN, IN SWAN WAIK......... .

Cheisea Physic Garden (circa I850), From THE River, BEFORE THE CONSTRUCTION OF THE CHELSEA EMBANKMENT . . . . . . . . . . . . . STATUE OF SiR HANS SIOANE, IN THE CHEI,SEA Physic Garden . . . . . . . . . 59

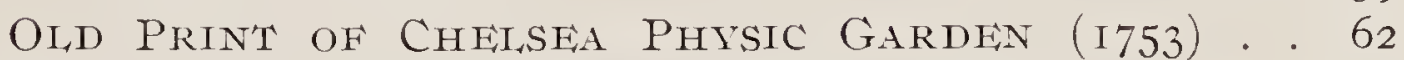
PLAN OF CHEISEA PHYSIC GARden, IN I9O5 . . . 89 IRIS FLORENTINA, I., GROWING IN THE CHEISLA PHYSIC GARDEN . . . . . . . . . . 9 9 48 GROWING IN THE CHEISEA PHYSIC GARDEN . . . 92 RHEUM PALMATUM, L., GROWING IN THE CHEISEA Physic GardenN . . . . . . . . . . 93 Range of Plant Houses, Cheisea Physic Garden 94 A MEDICAI ALOE, GROWING UNDER GLASS IN THE

Cheisea Physic Garden. . . . . . . . 95 

LONDON BOTANIC GARDENS.

BY PIERRE Élite FÉLIX PERRÉdìs, B.SC., F.L.S., Pharmaceutical Chemisí.

I.

\section{INTRODUCTORY.}

The origin of our Botanic Gardens may be traced to the private gardens of the herbalists of the sixteenth and seventeenth centuries. Among these the garden of John Gerarde, in Holborn, which was situated within little more than a stone's throw from the site upon which the Wellcome Chemical Research Laboratories now stand, may be cited as a noteworthy example. One of the main objects of these early cultivators was the determination of the characteristic features of plants used as remedial agents, and the framing of descriptions that would enable others to recognize such plants. It is not too much to say that many of their observations (e.g. those of Parkinson) are remarkably shrewd and accurate.

The Chelsea Physic Garden, established by the Society of Apothecaries of London, in 1673, was, to a great extent, based on the same plan as the gardens of these herbalists; but, unlike them, it was supported by a public body, so that it has survived to the present day. It was the first public institution of the kind in London, and it still remains as the oldest Botanic Garden in the metropolis.

Kew comes next in point of age, and its history as a scientific institution may be said to date from 1759, when William Aiton, a pupil of Philip Miller of the Chelsea Garden, was appointed by the Princess Augusta of Saxe-Gotha, Dowager Princess of W'ales, for the purpose of establishing a physic garden in what had hitherto 
been little more than the ornamental grounds of her residence. Kew is, therefore, in a measure, an offshoot of the Chelsea Physic Garden.

The last Botanic Gardens which remain to be considered in detail are those of the Royal Botanic Society, in Regent's Park. These were begun in I 839 by that Society, with the ultimate object of forming "extensive botanical and ornamental gardens withir the immediate vicinity of the metropolis," the purpose by which the Society was animated in so doing being the "promotion of Botany in all its branches, and its application to medicine, arts and manufactures."

Besides these, which constitute the only public Botanic gardens in London or its environs, mention must also be made of the Gardens of the Royal Horticultural Society, formerly at Chiswick, and now at Wisley, in Surrey. The Horticultural Society has, throughout, excluded the cultivation of medicinal plants from its field of operations, and this is a distinction which holds good, broadly, between "Horticultural" and "Botanic" gardens in this country. In view, however, of the importance of the Horticultural Society's Gardens from the cultural point of view, a short account of them will be given at the end of this introduction.

Before proceeding with the individual accounts of these gardens, it will not be without interest to pass briefly in review the salient features which they have in common, as well as those in which they differ from one another.

The arrangement of the plants in the gardens may conveniently be considered first, and affords much that is of interest. The Chelsea Garden, as we have just seen, was framed, in the main, on the pattern of the herbalists' gardens; to this we may add that one of the principal aims of its founders was the arrangement of plants in a systematic manner. At the close of the seventeenth century the plants were arranged according to the systems of Ray and Tournefort, and, in practice, this scheme is still partly adhered to, as a matter of convenience, in most Botanic Gardens, inasmuch as trees and shrubs are generally grouped apart from herbaceous plants. Towards the end of the eighteenth century we find the Linnean classification supplanting the systems of Ray and Tournefort, to be superseded, in turn, by those of Decandolle and Lindley towards the middle of the last century. Since the re-organization of the Garden in I902, 



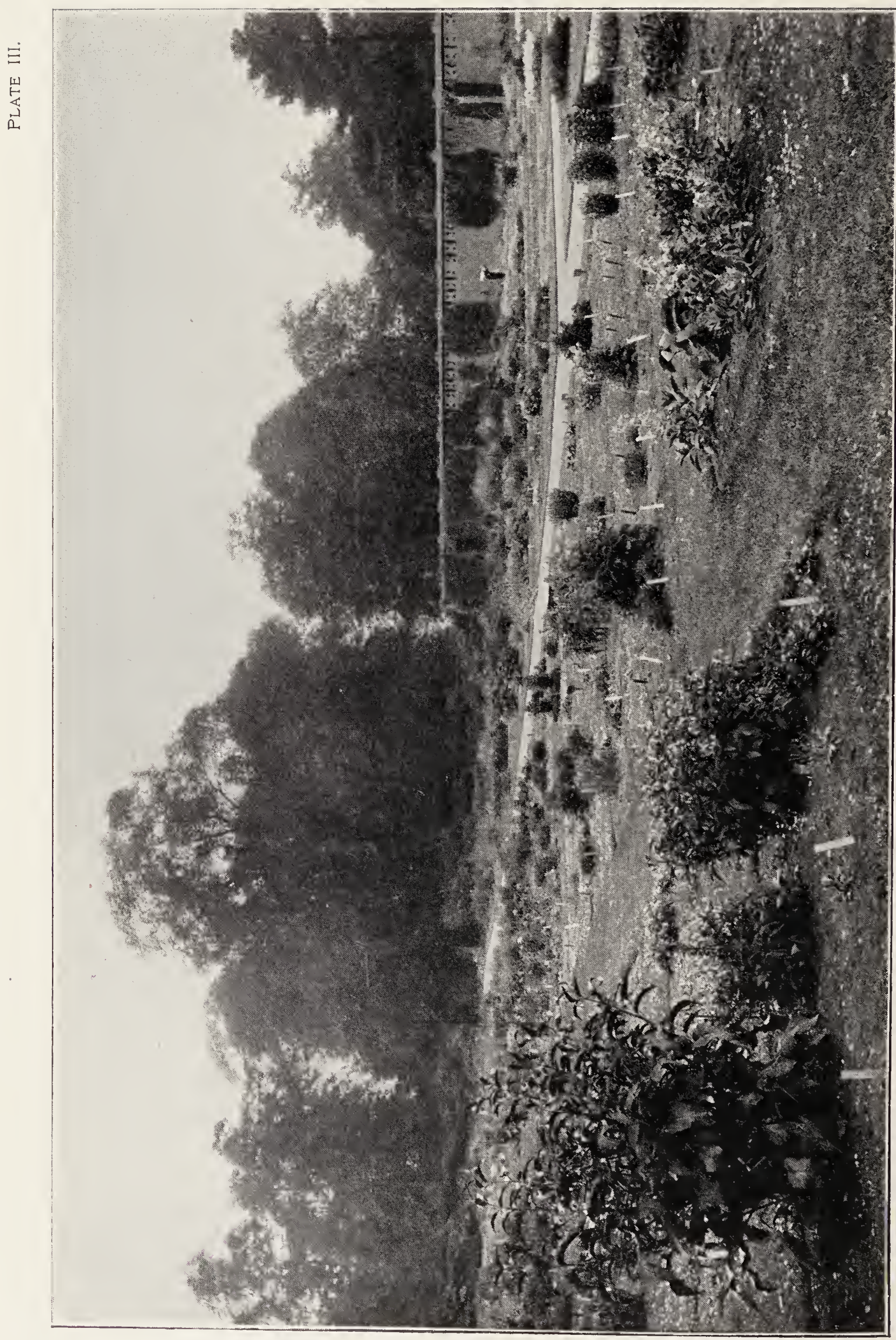




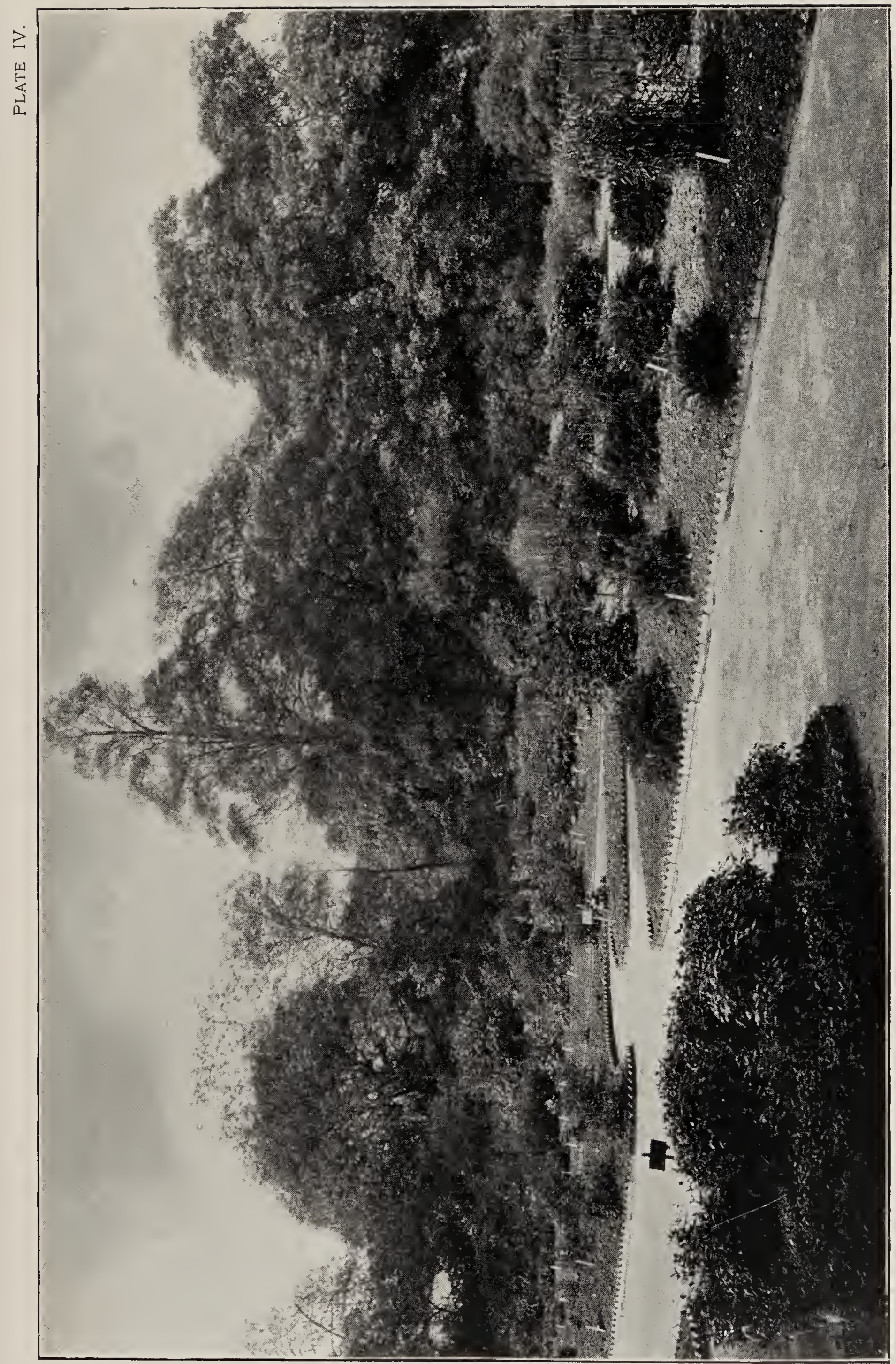

0
0
0 

the sequence of natural orders which has been followed, for the herbaceous plants that are arranged systematically, is that of Bentham and Hooker's "Genera Plantarum."

At Kew the arrangement adopted by Aiton was that of Linné, to be succeeded, as at Chelsea, by that of Decandolle, and, subsequently, during Sir J. D. Hooker's directorate, by that of Bentham and Hooker. It must be borne in mind that these changes could only be effectually accomplished with herbaceous plants, and that matters are complicated at Kew by the fact that, in addition to the plants which are arranged systematically, there are many others scattered about for artistic effect. In the present Arboretum, commenced in I $\$ 45$ by Sir William Hooker, and remodelled by his son, an arrangement in regular sequence of natural orders, such as that adopted for herbaceous plants, is not possible, but the Coniferce are grouped together to form a Pinetum, and most of the Amentifere are also in close proximity to each other. In the collection of shrubs, or Frum ticetum, the genera of the same natural order are, as a rule, grouped together. Beyond this, little attempt is made at systematic arrangement. In the possession of an extensive Arboretum, arranged systematically, so far as possible, Kew differs from the other two Botanic Gardens in London.

The herbaceous collection at the Regent's Park Gardens was ar. ranged according to natural orders from the first, and this system, has subsisted to the present time, with slight modifications. 'The plants, instead of being set out in parallel beds and arranged in regular sequence, as at Kew and Chelsea, are disposed in beds of various shapes and sizes; each bed accommodates one natural order, and these are grouped around one another according to their affinities.

When the gardens at Chelsea and Kew were started, medicinal plants were the predominant feature, and subsequently, special collections of medicinal plants were formed in both of them. A section for economic plants was also set aside at Regent's Park, but, with the exception of a small garden of hardy herbaceous medicinal plants at Kew, and of a belt of shrubs and trees formerly surrounding the herbaceous ground of the economic collection at Regent's Park, these have now been merged into the general herbaceous collections; and even in the case of Kew, by far the larger number of medicinal plants are to be found in the general collection.

In addition to the collections already enumerated, it is to be noted 
that alpine and aquatic plants require especial conditions for their successful cultivation, and such conditions are accordingly provided in the shape of rock gardens, water tanks, etc. As these plants, however, play an unimportant part in medicine, we may pass them over.

We have, so far, only considered plants growing out of doors, but a large number of medicinal plants from foreign lands would perish under ordinary conditions in this climate, so that some means had to be found by which the conditions of their habitats could be reproduced artificially, and this was attained by placing them in planthouses, heated if necessary. The name of "stoves" was given to houses in which artificial heat was employed, as stoves were used for producing the necessary temperature, while those which were not heated artificially were known as "greenhouses;" and these names have survived to the present day. These houses were originally buildings with large windows, and there is an example of them on an elaborate scale in the orangery at Kew (now Museum No. III), built in $176 \mathrm{I}$ (see Plate V). A stove was erected in the Chelsea Physic Garden as early as I68 I. We learn from Evelyn's "Diary" that its author went to see the keeper of the "Apothecaries' garden of simples at Chelsea" on August 7, 1685, and the following remarks which he makes in this connection give us an idea of the method of heating adopted: "What was very ingenious was the subterraneous heat conveyed by a stove under the conservatory, all vaulted with brick, so as he has the doores and windowes open in the hardest frosts, secluding only the snow;" it is also interesting to record that "the tree bearing jesuit's bark (Cinchona), which had done such wonders in quartan agues "was then growing in the collection at Chelsea. In 1760 we hear of the construction at Kew of a stove warmed by pipes containing hot air. The method of heating by hot water pipes appears to have been introduced by the Horticultural Society in their garden at Chiswick. Experiments were made with these as early as 1822 , but it was not until $I_{3} 8$ that they were brought to a satisfactory conclusion. The system of heating by hot water has now superseded all others.

Improvements in methods of heating were accompanied by advances in other directions, one of the chief of these being the use of iron for the framework of glass houses. The conservatory in the Regent's Park Gardens, erected in I 845 , was the first iron and glass 



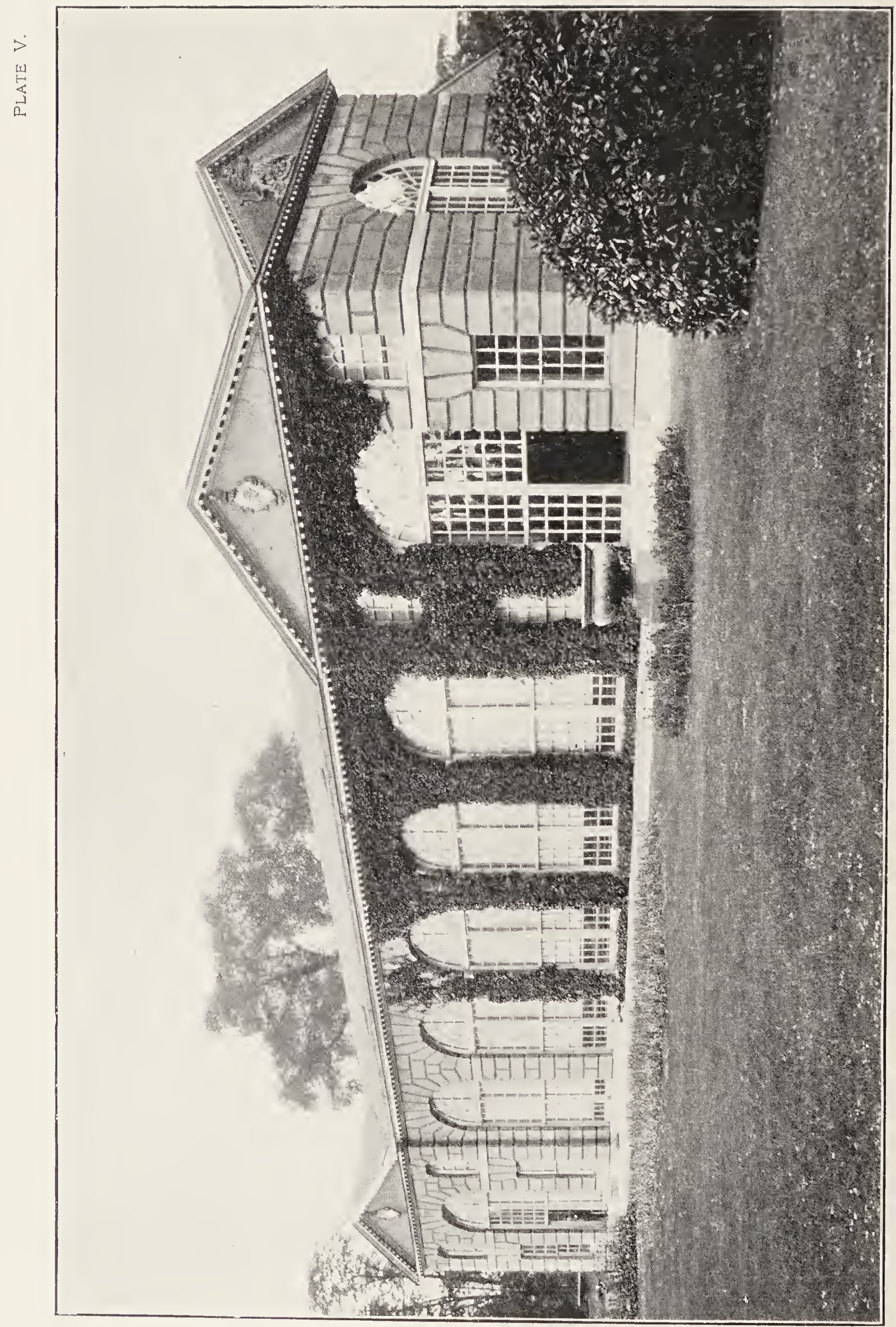

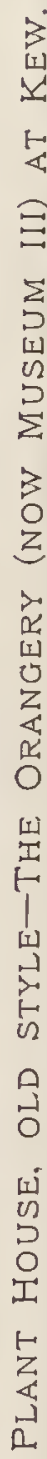




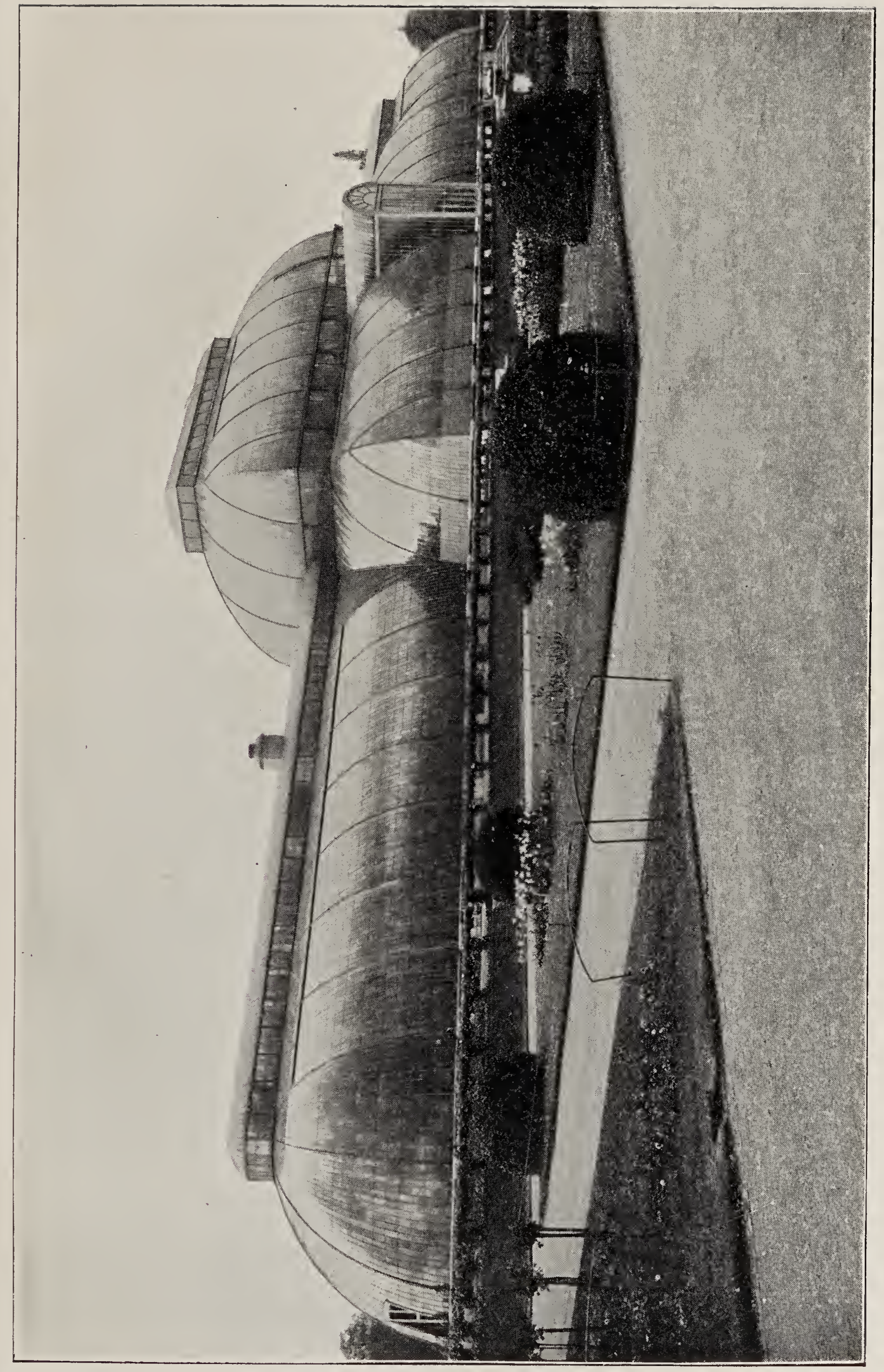

壵 

house of considerable size in England, and was soon followed by the far-famed Palm House at Kew (Plate VI). The framework of the smaller houses is usually of wood, as the additional strength which has been obtained by the use of iron in larger structures is not needed for buildings of smaller dimensions.

In each of the London gardens there is at least one range of plant houses, a "range" consisting of a series of glass houses in which the temperatures range from $65^{\circ}$ to $75^{\circ} \mathrm{F}$. in the tropical house or stove, to $45^{\circ}$ to $50^{\circ} \mathrm{F}$. in the cool house or greenhouse. At Regent's Park there is a range of three houses for economic plants solely, heated respectively to $65^{\circ}$ to $70^{\circ} \mathrm{F}$. (stove), $60^{\circ}$ to $65^{\circ} \mathrm{F}$. (intermediate house), and $45^{\circ}$ to $50^{\circ} \mathrm{F}$. (greenhouse). At Kew two houses of a range, one tropical, the other temperate, are devoted to economic plants, while at Chelsea the range of three houses, backed by a corridor, is used for the majority of the plants that require to be grown indoors. In addition to these there are larger houses at Kew for the accommodation of general collections of plants from tropical and sub-tropical countries and from the antipodes, such as the Palm House ("stove" heat) and the Temperate House, which consists in principle of a range of houses. The conservatory at the Regent's Park Gardens corresponds, in part, to the temperate house at Kew, while one of the wings is partitioned off as a small "Palm House." Houses for plants requiring special conditions are also provided, but the only ones that need be referred to here are those in which succulent plants, such as the various species of Aloe, are grown. Plants from arid regions, such as these, require a dry atmosphere, and special houses are accordingly provided for them at Kew and Regent's Park. Most of the succulents at the Chelsea Physic Garden are grown in one of the pits.

Owing to exigencies of space, very little systematic arrangement is attempted in the case of plants grown under glass, the nearest approach to this being in the Palrn House at Kew, where the smaller plants on the benches around the sides are grouped geographically. The method of arranging the plants most commonly adopted is such that the larger plants are placed in the center, in a span-roofed house (see Plate XII), or, if in a lean-to house, near the wall, while smaller specimens are grown in pots on benches around the sides.

Turning now to the functions by which the gardens are charac- 
terized, we find that Chelsea and Regent's Park have, in the main, played an educational rôle, whereas Kew stands out prominently as a center of scientific research and as the cradle of botanical enterprise in India and the Colonies. The history of the development of the respective gardens is of paramount importance in this connection, and a brief outline of this will, accordingly, be given.

The main considerations which led the members of the Society of Apothecaries to establish a garden at Chelsea, for the cultivation and systematic arrangement of indigenous and exotic plants, were that " their apprentices and others" might "better distinguish good and useful plants from those that bear resemblance to them, and yet are hurtful, and other the like good purposes." The garden, it is true, was, to some extent, utilized at first for the cultivation of plants to be converted into drugs for the Society's use, but this practice was soon abandoned. At a relatively early period in the history of the Society a "Demonstrator of Plants" was appointed in connection with the garden; James Petiver, F.R.S., officiated in this capacity as early as I709, but it was not until I724 that the Demonstrator of Plants, then Isaac Rand, was appointed to the superintendence of the garden, with the title of Prefectus Horti, or Director of the Garden. The duties of the office of Demonstrator of Plants and Prafectus Horti were defined in detail by a garden committee, on the appointment of William Curtis to the post in I773. The enumeration of these duties is of special interest, in that it gives us an insight into the nature of the work that the Society was doing at that time, in connection with its garden. That this was chiefly educational in character will be gathered from the provisions in question, which were, briefly, as follows: (I) The Society's Demonstrator of Plants and Prefectus Horti was to superintend the garden and library, and to encourage and cultivate the knowledge of botany among students of the Society; (2) "to demonstrate the plants, especially in the officinal quarter, with their names and uses," at least once a month, from April to September; (3) "to make some annual excursion, for two days at least," in the company of " two or three " competent " botanical members," for the purpose of collecting plants not commonly found near the metropolis, preparatory to a demonstration of the same at the Society's "General Herborizing"; (4) to "accompany and conduct the students of the Society in their search after indigenous plants" upon every day ap- 
pointed for the purpose; (5) to prepare annually a specified number of herbarium specimens; (6) "to attend each private court at the hall during the summer months," in order to give advice on matters relative to "the private herborizings" and to the management of the garden; he was also recommended to cultivate "extensive botanical correspondence, both at home and abroad."

The reputation of the garden as a center for the diffusion of knowledge was, moreover, much augmented between 1722 and I 770 by the exertions of Philip Miller, who was appointed gardener in I722, and who published in I 730 the first catalogue of the officinal plants growing in the Chelsea Garden. This will be considered in greater detail later, but it is of interest to note that, although the book is written in Latin, every plant mentioned has an English name appended to it, a feature which must have considerably enhanced its value to the learner. Two other works of which Philip Miller was the author, viz., the "Gardeners Dictionary" and "A Short Introduction to the Science of Botany," added in no small degree to the reputation of the Chelsea Garden as an educational center, but the most far-reaching result of Philip Miller's labors is probably to be found in the fame achieved by his pupils, such as Aiton at Kew, and his own successor at Chelsea, William Forsyth.

In I 29 an extension of the Society's work was inaugurated, consequent upon a resolution of the Garden Committee to the effect that the garden should be made "more useful to the profession at large than it had hitherto been," and medical students from the recognized metropolitan schools were admitted, free, to the garden once a week, on the recommendation of their respective teachers. The result was so successful that in the following year the Society's demonstrator was appointed professor at an increased salary, and lectures were delivered by him once a week to all accredited medical students who chose to take advantage of them. Two medals presented by the Society were also offered for competition annually. A large number of students availed themselves of the privilege granted to them by the Society, and in the same year "by far the best catalogue of the medicinal plants in the Chelsea Garden ever published" was issued by the professor, J. L. Wheeler. This work was at the same time a guide to medical botany, and, although the classification adopted was that of Linné, it is of the greatest interest 
to note that a synopsis according to the system of Jussieu was also added.

This important phase of the Society's work was continued until I 853 , and, between the years I836-I 853 the fame of the Chelsea Garden was at its zenith, largely owing to the disinterestedness and boundless activity of that great man, John Lindley, who occupied the post of Professor of Botany and Prefectus Horti during that period. In 1853 , the Society, hampered financially by the expenses involved in this work, decided to relieve the strain by working their garden more economically in the future. The lectures in the garden were discontinued, the office of Prafectus Horti was abolished, and the cultivation of plants requiring artificial heat was abandoned. The annual prizes were, nevertheless, still awarded, and, in I863, chiefly through the efforts of one of the Society's members, Nathaniel Bagshaw Ward, the inventor of the "Wardian Case," an attempt was made to restore the garden to a semblance of its former standing. The garden still continued to attract a number of medical students, but these were gradualiy drawn to the more easily accessible Regent's Park Gardens. In I 878 a prize competition, open to women only, was instituted by the Society with the object of en. couraging the study of botany among women students. Notwithstanding these spasmodic attempts to infuse new life into the work of the garden, its importance gradually decreased until it sank into insignificance; it was saved from oblivion during this period, however, by its curator, Thomas Moore, who had been elected to the post in 1848 on the recommendation of Lindley. Thomas Moore was co-editor of the "Treasury of Botany" with Lindley, and it is chiefly to his labors that we are indebted for that invaluable dictionary of the vegetable kingdom; a work which has probably contributed, in a greater degree than anything else, to make the name of the Chelsea Garden known throughout the world. In I 899 the Trustees of the London Parochial Charities were appointed trustees of the garden, and a committee of management, to be described later, was appointed; new plant houses, a lecture-room and laboratory, etc., were erected, and, in 1902, the garden was formally re-opened. The rôle of the garden is still mainly an educational one; specimens of living plants are supplied to a number of colleges and schools, the laboratory is used for physiological work by the students of the Royal College of Science, and advanced courses of 


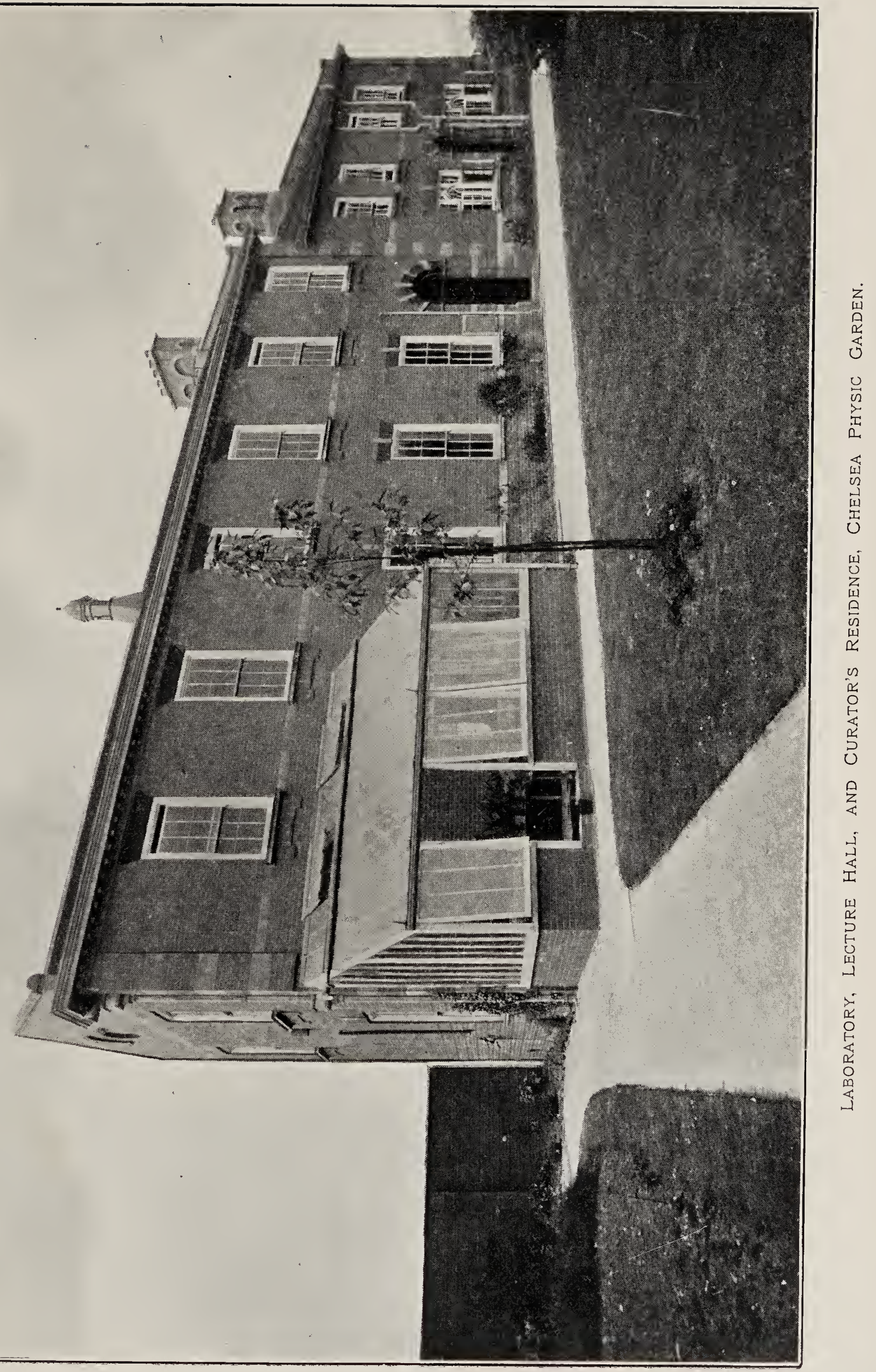



university lectures are delivered in the lecture-hall. Since its reorganization, however, the garden has also been used for purposes of research, notably by Mr. Francis Darwin and by Sir William Ramsay.

The Royal Botanic Society's Gardens in Regent's Park have had but a short history, and, after what has been said in connection with the Chelsea Garden, it can be summarized in a few lines. The cultivation of medicinal and other economic plants has always been fostered by the Royal Botanic Society, and, in consequence of this, teachers in the medical schools soon found it advantageous to make use of its gardens for the instruction of their pupils; for many years the late Professor Bentley delivered lectures in the gardens at 7.30 o'clock on certain mornings to the students of the Pharmaceutical Society's School. The distribution of cut specimens of plants to medical schools and other educational institutions (sometimes to the extent of 60,000 specimens per annum) was an innovation which helped to extend the sphere of usefulness of the Regent's Park Gardens, and these still remain the principal source of supply for fresh botanical specimens to the majority of the medical schools in London. One of the earliest features introduced by the Society into its gardens was an exhibition ground where exhibitions of plants and flowers were held periodically; of later years some of these displays have been developed into very instructive exhibits of botanical work done in schools. The museum, erected in I85 I, was originally furnished with specimens for educational purposes solely; the collections have since been considerably extended, more especially by the addition of economic products derived from the vegetable kingdom, but the educational element still preponderates in the collections, which are hardly of sufficient extent to be used for purposes of reference as at Kew. In 1897 a practical gardening school was established by the Society. In connection with this, a portion of the gardens has been specially set aside for horticultural work, and a laboratory, which is also used as a lecture-room, has been erected. The Royal Botanic Society's Gardens are also utilized as a pleasure-ground by its Fellows and others, but the consideration of this factor hardly comes within our province.

The botanical history of Kew Gardens has been traced to the colIections of exotic plants made by Lord Capel in his grounds at Kew, during the latter half of the seventeenth century. It was not until 
nearly a century later, however, that these grounds became something more than the pleasure gardens of a private mansion, containing a collection of "curious and ornamental plants" for the delectation of their owners.

For us the history of Kew begins with the installation of William Aiton as chief gardener to the Princess Augusta in I759. With the co-operation of her scientific advisor, the Earl of Bute, this princess fostered the scientific development of Kew; and from Dr. Hill's catalogue of plants in the exotic garden of Kew, published in I 768 , or nine years after Aiton's appointment, we are able to perceive that the cultivation of exotic plants at Kew had been pursued with vigor. A further development in this direction occurred in I 772, when the first collector, Francis Masson, was sent out from Kew to the Cape. One of these early collectors, David Nelson, was assistant botanist on Cook's third voyage (I776-I779), and to him we are indebted for a collection of New Holland (Australian) plants, which contained the specimen from which the genus Eucalyptus was first described. In 1772 the Princess Augusta died, but her son and successor, George III, not only continued the work which his mother had begun, but he made its success assured by choosing Sir Joseph Banks as his scientific advisor in place of Lord Bute, and by entrusting to him the supervision of Kew Gardens. The collections increased rapidly, and in I 788 a house for the reception of Cape plants was erected, and another for Australian plants in $\mathrm{I} 792$. The "Hortus Kewensis" of William Aiton was published in 1789 , and in this important work accounts were given of these numerous acquisitions. It is to the influence of its collectors abroad during this period that Kew gradually came to be looked upon as the botanical headquarters of the Colonies. The collections accumulated by Sir Joseph Banks, the resources of his library, the magnificent illustrations of plants executed under his direction by the Austrian artist, Francis Bauer, and the unprecedented facilities for cultural experiment, effected, on the other hand, the transformation of Kew into a research center. After the deaths of George III and Sir Joseph Banks, in I 820, the activities of Kew suffered an eclipse until the reorganization of the institution in $184 \mathrm{I}$. In that year Kew was placed in charge of a government department and became the property of the nation. Sir William Hooker was appointed director, and under his control and that of his successors in office the policy inaugurated by Sir Joseph 
Banks has not only been continued and developed, but the desire of the general public for a delightful pleasure-ground in the neighborhood of the metropolis has also been abundantly gratified.

The colonial expansion, nurtured during the closing years of the eighteenth century and at the beginning of the nineteenth, has been steadily developed in various ways. Botanic establishments have been founded in the various Colonies, and these have, for the most part, received their inspiration from Kew. The means by which this relationship has been brought about are briefly these: (a) The staffs of the Colonial establishments have been mainly recruited from Kew; (b) Kew, by collecting, propagating and redistributing new species and varieties of economic plants has thereby served as a connecting link between the various Colonial establishments; $(c)$ Kew has, by virtue of its advantages, accumulated an extensive herbarium and unique collections of economic products, and it possesses a staff of experts as well as a comprehensive library. We find, as a result, that the Colonial establishments have come to consider Kew in the light of a central bureau of information on matters of cultural and botanical import, and in response to this feeling a "Bulletin of Miscellaneous Information" was issued periodically from Kew during a period of thirteen years (I887-I 899). But this is not all, for Kew, at the request of the Government, has from time to time directly carried out important undertakings for the especial benefit of the Colonies, such as the introduction of cinchona into India, the investigation of the coffee disease in Ceylon, and the inquiry into the economic resources of the West Indies by the former assistant director, Sir Daniel Morris, K.C.M.G., who is now Commissioner of Agriculture for Barbadoes, the Leeward and the Windward Islands.

The demand for men trained at Kew led to the adoption, in I 874, of a course of systematic instruction similar to that initiated fortyeight years previously by the Royal Horticultural Society in its gardens at Chiswick, and this training of gardeners constitutes the only direct educational work that has ever been undertaken at Kew. Indirectly, however, Kew has been instrumental in promoting the teaching of botany in other institutions, as the following examples will testify: It is to the ex-Director of Kew, Sir Joseph Hooker that we are indebted for one of the most authoritative text-books on the flora of these islands, viz., "The Student's Flora of the British Islands." The "Primer of Botany," by the same author, has also 
done much to encourage the teaching of botany in elementary schools, and the same may be said of the "Elementary Lessons in Botany," from the pen of Prof. Daniel Oliver, who was formerly Keeper of the Herbarium at Kew and Professor of Botany at University College. The formation, in I880, of a students' garden, in which students were allowed to gather specimens, was as its name implies, designed to meet the needs of the botanical student; and the supply, from time to time, of cut specimens to a number of schools and colleges has also subserved educational ends. It must be noted, however, that the work accomplished by Kew in this direction has been largely adventitious in character, and has of later years been relegated to the Chelsea Physic Garden and to the Gardens in Regent's Park, as evidenced by the suppression of the students' garden and by the withdrawal of supplies to schools. Kew, as a matter of fact, is not of much assistance to the elementary student, except in so far as it enables him to obtain a general view of the vegetable kingdom and its products. To the student of forestry, however, the Arboretum is invaluable, and the Indian Forest students from Cooper's Hill visit the gardens weekly during the Summer months on that account.

The work of Kew in the field of research has been so extensive and so varied that it will be necessary for us to consider these activities in a general way, and to content ourselves with the selection of a few illustrative examples.

The branch of botanical research in which Kew has achieved the greatest fame is, undoubtedly, that of Systematic Botany. The Hortus Kewensis, a work which has already been mentioned, was the most important contribution to Systematic Botany that

1 i

the 'Hortus Kewensis,' a work of three volumes, published in I789, with the name of William Aiton, the King's gardener, on the titlepage as author. It was actually the work of Daniel Carl Solander and of Jonas Dryander, in succession librarians to Banks ; the original specimens from which the descriptions were drawn up are incorporated in the Banksian herbarium which is now in Cromwell Road [British Museum (Natural History)]. The second edition of this book in five volumes, 11ominally the product of William Townsend Aiton, son of the elder Aiton, was written partly by Jonas Dryander, who succeeded as Banks' librarian after the death of Solander, and completed by Robert Brown, who became librarian wlen Dryander died in ISIo; the book appeared in I8IO-ISI3." -Mr. B. D. Jackson in "Return. House of Commons." I90I, 205, D. II 2 . 
emanated from Kew before $184 \mathrm{I}$. This, however, is an inconsiderable accomplishment when compared with later monumental works, such as the Genera Plantarum, of Bentham and Hooker; the Index Kervensis, of Hooker and Jackson, and the series of Colonial floras-e.g. the "Flora of British India," the Flora Capensis, and the "Flora of Tropical Africa,"-by various members of the staff and others. These achievements have only been rendered possible by the existence, at Kew, of a great Herbarium and an extensive Library. The herbarium of Sir Joseph Banks, his scientific library, and the collection of Bauer's drawings, had all been transferred to the British Museum after his death, so that the present Herbarium and Library, on which these publications are chiefly founded, are independent creations, in which the labors of Bentham and the two Hookers have played an important part.

Curiously enough, it was also from Kew, the systematist's stronghold, that the movement originated which replaced the study of Systematic Botany in our universities by that of other branches of the science, such as morphology, physiology and cytology; for this result came about chiefly through the influence of the Jodrell Laboratory, completed in 1876 , and of the English translation of Sachs' Text-Book of Botany, in the preparation of which the present Director of Kew assisted. Furthermore, it is of interest to record that the reaction which has become perceptible during the last few years, as well as the trend in the direction of ecological research, had its origin, not at Kew, but in the universities themselves. The work which has been accomplished in the Jodrell Laboratory is largely physiological in character, but cytological, morphological and anatomical investigations have also been actively prosecuted, as instanced by the epoch-making palæontological researches of Dr. D. $\mathrm{H}$. Scott, illuminated by those of his associates, Messrs. W. C. Worsdell and L. A. Boodle, on modern plants. Among the researches that are of interest to pharmacists we may note Cross and Bevan's work on cellulose and de Wevre's investigations on Cubebs.

The first economic museum at Kew was established in $\mathrm{I} 847$, when Sir William Hooker adapted the building now known as Museum No. II, for the reception of "all kinds of Fruits and Seeds, Gums, Resins, Dyestuffs, Drugs, Sections of Woods and all curious vegetable products, especially those that are useful in the Arts, in Medicine and in Domestic Economy." It is from these small beginnings that the 
present extensive collections, requiring three museums for their accommodation, have been developed, largely through the liberality of the Indian Government and of the India Office. The existence, side by side, of extensive collections of drugs, of a unique Herbarium, and of important living collections, has presented a wide field to investigators in the domain of pharmacognosy, and we accordingly find that pharmacists who have distinguished themselves in that branch of their calling have invariably availed themselves of the facilities provided by Kew. Among these workers we may mention J. E. Howard, Daniel Hanbury, and E. M. Holmes, not forgetting that many investigations on economic botany have been contributed to the Kew Bulletin by members of the staff at Kew.

This survey of the London Botanic Gardens would not be complete without some reference to their administration, and, with a brief account of this, we may appropriately conclude our introduction.

Kew is administered by a government department, namely, the Board of Agriculture, but the organization and direction of the scientific work of the establishment are entirely in the hands of the Director.

The Royal Botanic Society, on the other hand, is a self-supporting body, and depends for its existence upon the subscriptions of its Fellows. The Society's Gardens in Regent's Park are administered by a garden committee of the Council, the Council itself being elected by vote of the Fellows. The executive officer is the Secretary.

The government of the Chelsea Physic Garden is vested in a committee of management consisting of members appointed by the Trustees of the London Parochial Charities, the Treasury, the Lord President of the Council, the Technical Education Board of the London County Council, the Royal Society, the Society of Apothecaries, the Royal College of Physicians, the Pharmaceutical Society, the Senate of the London University, and the representative of Sir Hans Sloane. The Professor of Botany in the Royal College of Science is Scientific Advisor to the Committee, while the funds necessary for the maintenance of the garden are derived chiefly from grants by the London Parochial Charities and the Treasury. 


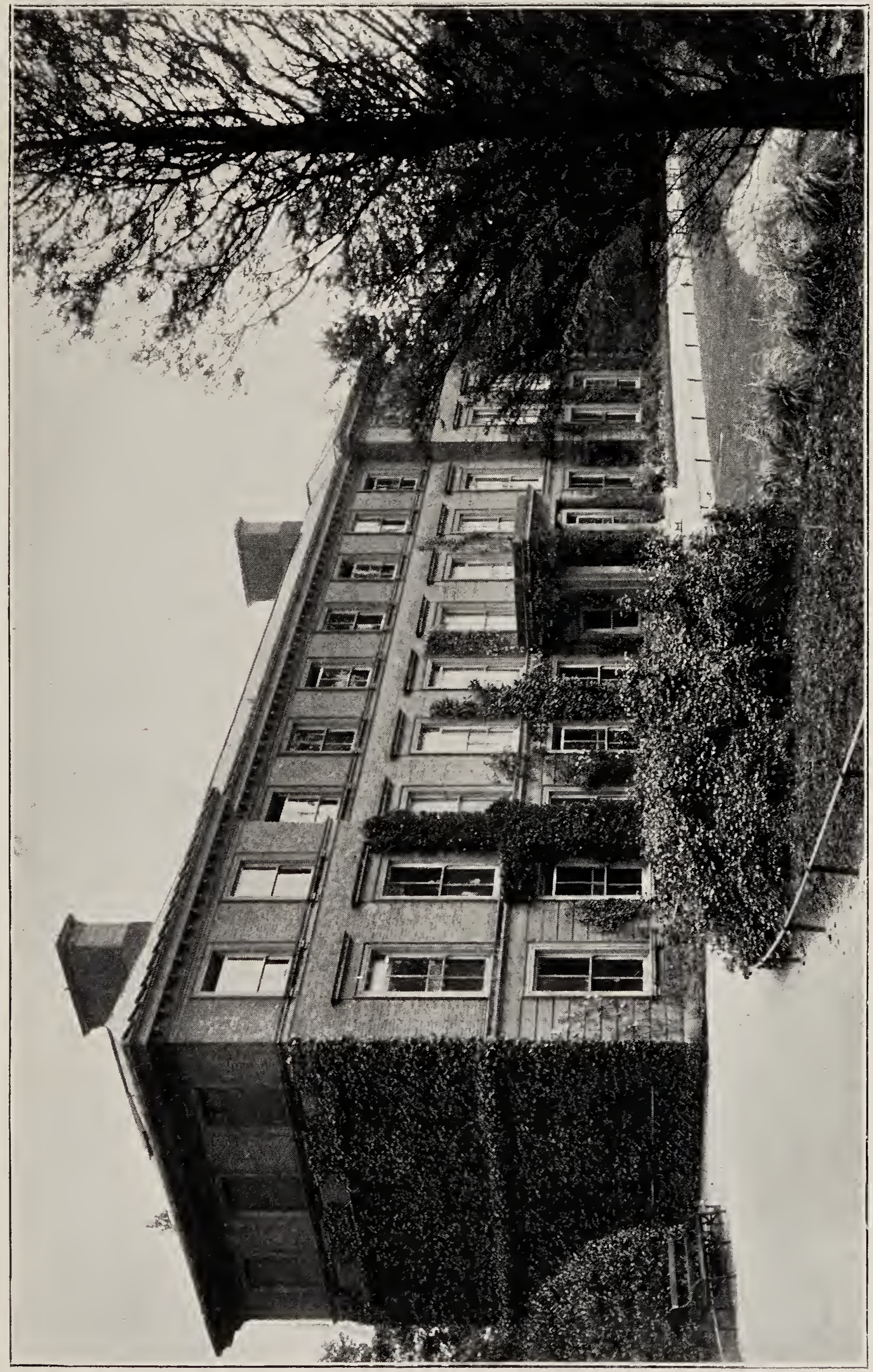

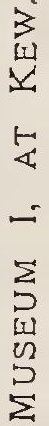



THE ROYAL HORTICULTURAL SOCIETY'S GARDENS.

The Royal Horticultural Society of London was founded in I 804 for the purpose of encouraging the cultivation of ornamental and useful plants. The latter class comprises forest trees and plants yielding various food products, such as fruit trees and culinary plants, but those which fall more particularly within the province of agriculture or medicine a re excluded. In 1809 the Society obtained its first charter, and in I 8 I 8 a first attempt was made towards the establishment of a garden. In I 8 I 9 another piece of ground was taken at Ealing, and the work accomplished there was further supplemented by that of nurserymen in the neighborhood of London, to whom nursery stock and plants were lent. These undertakings, however, were tentative in character, and it was not until I 82 I that they took definite shape. In that year the Chiswick Gardens, then thirty-three acres in extent, were established, and they survived, through many vicissitudes, until I904, although having then shrunk to an area of twelve acres. Between I 86I and I 887 the activities of the Chiswick Gardens suffered an almost total eclipse, owing to the fact that the Society was involved during that period in a scheme which absorbed all its energies and crippled its finances. This scheme, fostered by the late Prince Consort, consisted in an agreement between the Society and the commissioners of the Great Exhibition of $185 \mathrm{I}$, by which the management of the gardens and conservatory at South Kensington was entrusted by the commissioners to the Society on certain conditions. These conditions were not fulfilled, and in 1887 the commissioners appropriated the land for other purposes. This action led to the reorganization of the Society on its former basis and to the renewal of activities at the Chiswick Gardens. For some time past, however, these gardens, owing to their limited size and to excessive drainage and smoke, had been found unsuitable for the purpose which they were designed to serve. The need of the Society for more suitable accommodation was met in 1903 by Sir Thomas Hanbury, K.C.V.O., who purchased 60 acres of land at Wisley, in Surrey, including the celebrated wild garden of the late G. F. Wilson, F.R.S. This property was placed in trust for the use of the Society, so long as it continued to be used by the latter for the objects aimed at by its founders. Among the prominent features that the Society is introducing into its new gardens 
we may mention a collection of named varieties of fruit trees, a series of glass houses for experimental culture, and a representative arboretum and rose garden, while the establishment of a physiological laboratory is also contemplated.

This description of the gardens themselves must suffice, but some of the salient features of the work accomplished by the Society prior to I860, in connection with its gardens, will be touched upon. The Kew system of sending plant collectors abroad was adopted by the Society in I8I8, and the plants sent home by them helped to form the collections in the gardens at Chiswick. Among these emissaries mention may be made of George Don, who was sent out in $\mathrm{I} 82 \mathrm{I}$ to the West Indies and Brazil; of David Douglas, who explored western North America between I 823 and I 834 and introduced many interesting ornamental plants and forest trees; and of the renowned Robert Fortune, who was sent to China by the Society in I 842. In I 822 Lindley was appointed assistant garden secretary to the Society, and four years later he became its sole assistant secretary. George Bentham was honorary secretary from I829 to I840, and it was to the labors of these two distinguished men that the fame of the gardens in their early days was chiefly due. In I 826 a course of training was inaugurated in the gardens, and this is of interest, inasmuch as the Society was the first in this country to train gardening students. Among the Society's pupils who subsequently achieved distinction we may note Archibald Barron; Sir Joseph Paxton, who designed the Crystal Palace ; Robert Thompson; and many others. Bentham and Lindley organized the first flower show at Chiswick in $\mathrm{I} 833$, and it was also during their period of office that the system of heating plant houses by means of hot-ivater pipes was first resorted to. The naming of the large number of new plants introduced by the Society was carried out principally by Bentham, with the assistance of Lindley, until the resignation of the former from the secretaryship in $184 \mathrm{I}$; the major part of the Society's work then devolved upon Lindley, and, until illness compelied him to relinquish his duties, he was the moving spirit in all the Society's activities. It is in connection with this matter of nomenclature that the Society has rendered one of the greatest services to horticulture, as it is the home of the nomenclature of fruit as well as the parent of the Colonial fruit industry which has now assumed extensive proportions. The first publication issued by the 



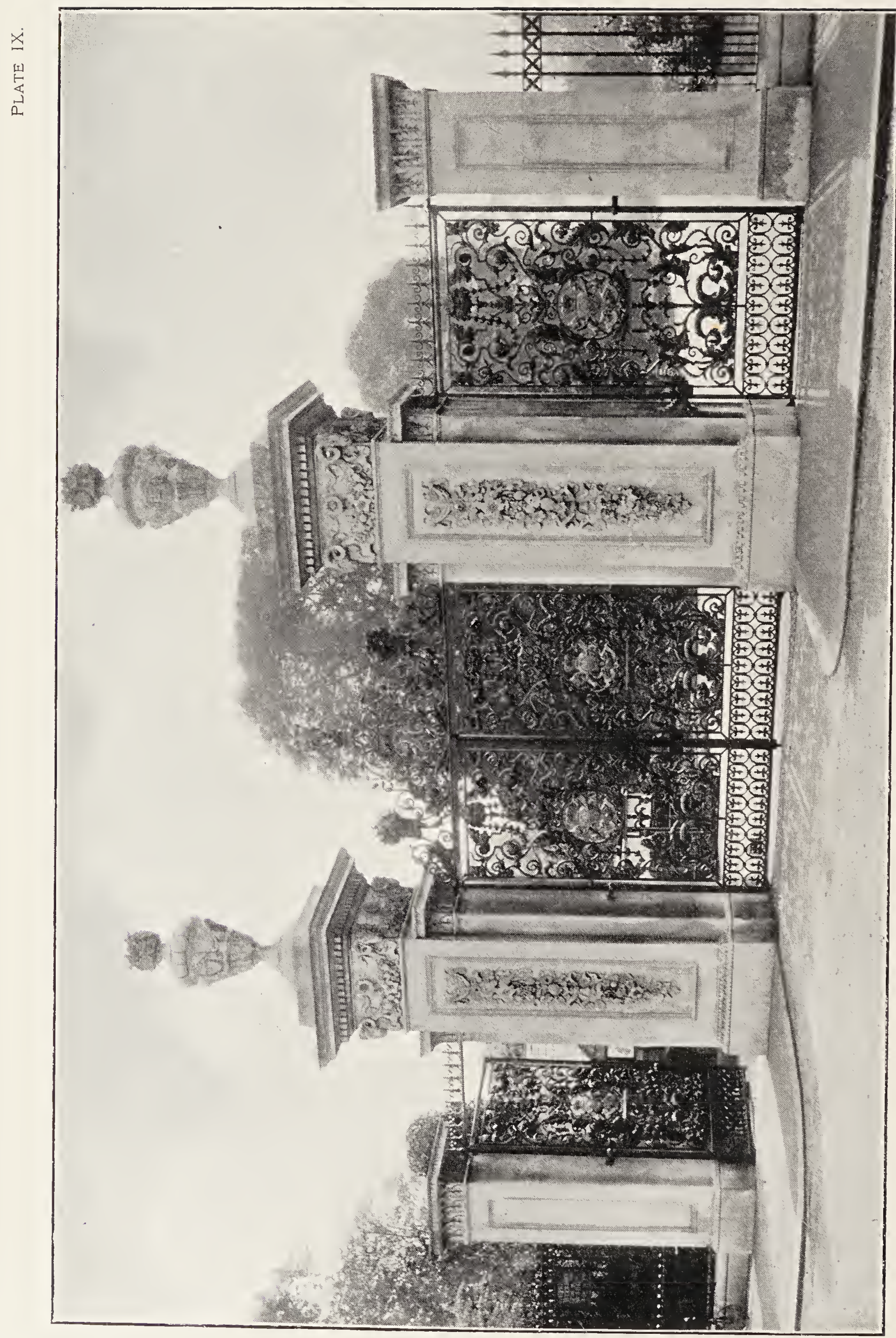


Society was the Transactions. This was published from I 805 to I 848 , and was followed in 1846 by the Fournal, which has been issued periodically ever since and now constitutes the most important publication of the Society.

II.

KEW GARDENS.

The present Royal Botanic Gardens at Kew are the result of the fusion of two royal domains, viz., (I) Richmond Gardens, and (2) the original Kew Gardens-the latter corresponding roughly to the private grounds of Kew House, a substantial private house which was demolished in 1803 . This fusion, contemplated by an Act of Parliament passed in 1765 and giving George III power to cause the lane separating the two gardens "to be shut up and discontinued," was eventually accomplished in 1802 .

It will be convenient to deal separately with the histories of these, prior to their fusion, beginning with that of Richmond Gardens.

\section{RICHMOND GARDENS.}

These gardens, which have contributed the western half to Kew as it exists to-day, were associated with a royal residence as far back as the reign of Edward I, who converted the "Manor House at Sheen," which lay to the south of the gardens, into a royal palace. This building was burnt down in the reign of Edward VI, by whom it was rebuilt and named Richmond. It was sold in I650, and its reversion to royal hands appears to have taken place in the reign of Queen Anne or of William III, although the accounts dealing with the history of the palace and its gardens during this period are somewhat conflicting; they are known, however, to have been in the possession of the Duke of Ormonde for several years before they became the property of Queen Caroline, wife of George II.

The palace had been rebuilt a second time by the Duke of Ormonde, and Queen Caroline spent large sums in converting the gardens into pleasure grounds and adorning them with ornamental buildings. Queen Caroline died in 1737, and Richmond Gardens remained unchanged until George II's death in I760, but all traces of her occupation were obliterated in the reign of George III. In the early part of the nineteenth century "Love Lane," which separated these from the original Kew Gardens, was abolished, as mentioned above. 
KEW HOUSE AND ITS GROUNDS.

The building stood in the private grounds of the present palace and to the south of it. Lord Capel, of Tewkesbury, who died Lord Deputy of Ireland in 1696 , came into this property by marriage with the daughter and heiress of its former owner, Richard Bennett, Esq. Lord Capel was much devoted to the culture of plants, and it is to his collections that the origin of the botanical history of Kew is traced. Lady Capel survived her husband, and died in I72I. Kew House then passed to Samuel Molyneux, Esq., who had married Lady Elizabeth, grand-niece of Lord Capel. About the year I730, Frederick, Prince of Wales, obtained a long lease of Kew House and its gardens from the Capel family, and caused a new arrangement of the gardens to be carried out. He died in I 75 I, and his widow, the Princess Augusta of Saxe Gotha, Dowager Princess of Wales, who survived him for twenty-one years, gave to them the sciensific character which has since developed into their most salient feature. In 759 William Aiton, a former pupil of Philip Miller at the Chelsea Physic Garden, was engaged by her to establish a Physic Garden. John Haverfield was chief gardener, and on the death of George II in I 760 appears to have had Richmond Gardens put in his charge, Aiton remaining at Kew. When Haverfield died in $\mathrm{I} 784$, Aiton succeeded to Haverfield's post, and, until his death in I793, the management of both gardens was entrusted to him. Soon after Aiton's appointment extensive works were carried out at Kew, notable among these being a "stove" warmed by pipes containing hot air.

The practice of sending out collectors from Kew was inaugurated during Aiton's period of office, when Francis Masson was sent to the Cape in I772, remaining there three years. It is to one of these early collectors, David Nelson, assistant botanist on Cook's third voyage (I776-1779), that we are indebted for the specimen on which the extensive genus Eucalyptus was founded by L'Héritier.

In $\mathrm{I}_{9} 8_{9}$ William Aiton published his Horlus Kewensis or catalogue of plants growing at Kew. This work, which was the forerumner of the present elaborate hand-lists of plants grown at Kew, contains descriptions of 5,500 species, classified according to the Linnean system.

In connection with Aiton's Hortus Kervensis it is worthy of note 
that the name of Sir Joseph Banks is of the most frequent occurrence in it; a fact which reminds us of the influence that this indefatigable patron of natural science wielded at Kew during the latter part of the eighteenth century and at the beginning of the nineteenth. Under the Princess Augusta's control of the Gardens, John Stuart, third Earl of Bute, had been her scientific advisor, and had taken an active part in the botanical development of Kew. George III, after the death of his mother, the Princess Augusta, in I 772 , fostered this development, and eventually bought the freehold of Kew House and its gardens from the Dowager Countess of Essex. Until the death of this monarch in I 820, Sir Joseph Banks occupied a similar position to that previously held by Lord Bute (who had fallen out of favor with George III), and became, virtually, director of Kew. Under his direction the gardens enjoyed a period of exceptional activity, and became a centre of botanical exploration and horticultural experiment unparalleled before or since.

William Townsend Aiton succeeded to the post which his father, William Aiton, had so ably filled, and published a second edition of the Hortus Kewensis in I8I3. The efficiency of Kew, however, was mainly dependent upon the direction of Sir Joseph Banks, stimulated by the interest which George III took in his domains at Richmond and Kew. When the King became permanently insane, in I $8 \mathrm{Io}$, a retrograde movement set in which continued for the next thirty years. Sir Joseph Banks and King George III both died in I 820, and during the two succeeding decades after their deaths, Kew practically ceased to have any standing as a scientific institution, and its collections were dismembered, the most valuable of them being deposited in the British Museum.

Before passing on to the events which reinstated Kew to its former position, a short summary will be given of the salient facts in its history which have not already been dealt with. Among the many evidences of Sir Joseph Banks' energy, mention may be made of the magnificent drawings of plants executed by Francis Bauer, an Austrian, who, with the King's sanction, was engaged in I790 as draughtsman to the Botanic Gardens. Albeit, Sir Joseph Banks paid his salary during his own lifetime and arranged for its continuance after his death. Another of Sir Joseph Banks' projects was the foundation of a herbarium and library at Kew; a beginning was made with the latter, but the former was not effectually accomplished 
until I 852, when the oldest portion of the present building was first used for that purpose. It was this very building, known in Banks' time as "Hunter House," that he had proposed to utilize for the purpose indicated.

The beginning made in 1802 towards the incorporation of Richmond with Kew Gardens seems to have progressed but slowly. It will, however, be convenient to treat them as one from this date, and to consider them under the general heading of

\section{KEW GA'RDENS AND PLEASURE GROUNDS.}

In I 823 George IV acquired the western portion of Kew Green, including an old road which led from thence to Brentford Ferry; the wall which divided the Royal Gardens from this road was removed by William IV in I 830 . By these means a portion of the present herbarium and the whole of its site, the old Kew Gardens, and the former Richmond Gardens, became a single royal domain; and the fusion proved, incidentally, to be the first step towards the opening up of Kew to the public.

In the reign of William IV,W.T. Aiton had become DirectorGeneral of Kew, but in addition to this he held numerous other posts, with the result that Kew received little attention, especially as the sovereign took comparatively little interest in it. The pres. ent plant house, near the main entrance, is, however, an heritage from William IV, who had it removed there from Buckingham Palace. It has already been indicated that the gardens had been rendered accessible to the public; and in proportion as the interest of kings decreased, that of the public increased. It is recorded in I 825 that Kew was open to the public on Sundays from Midsummer till Michaelmas, and, in I 838, Lindley reported that visitors were admitted unreservedly to the gardens daily except Sundays. It was about this time that public interest became so intensified by unfavorable criticisms on the condition of Kew by various scientific men, nctable among these being Lindley, that the Treasury, in January, I $8_{3} 8$, the year after William IV's death, appointed a committee "to enquire into the management, etc., of the Royal Gardens." This committee, consisting of Lindley; Mr. (afterwards Sir Joseph) Paxton, gardener to the Duke of Devonshire; and Mr. Wilson, gardener to Lord Surrey, reported in the following month. The report is of great interest, as it gives a detailed account of the configuration of the gardens and of the extent of their contents at that time. 
Between the reporting of Lindley and the presentation of the report to Parliament, it became known that the Lord Steward, then Lord Surrey, who by virtue of his position had control of the Kew Gardens, had, after visiting the gardens, offered the plants in the houses to the Royal Horticultural Society at Chiswick and the Royal Botanic Society at Regent's Park, with the intention of converting the houses at Kew into vineries and pine stoves. Both of the gardens in question refused the offer, but it was, nevertheless, Lord Surrey's intention to put his vinery project into execution. The effect of this was to rouse public indignation, and Lord Surrey's pro. ject was accordingly abandoned, with the ultimate result that "the charge of the Botanical and all other gardens . . . . at Kew, except the Kitchen Gardens," was transferred to the Commissioners of Woods and Forests by a Treasury minute of March I I, I 840. W. T. Aiton resigned his directorship of the Botanic Gardens at the end of the same year, but retained that of the Pleasure Grounds until I 845. Sir William Hooker, F.R.S., who was Regius Professor of Botany in the University of Glasgow at the time of Aiton's resignation, was appointed Director of the Botanic Gardens and became duly installed on the Ist of April, I 84I.

With Sir William Hooker's installation as Director of Kew, what we may call the rejuvenescence of the institution began, and Kew became a complete national establishment. After Aiton's relinquishment of the direction of the Pleasure Grounds, Sir William became director of the whole. The aims which Sir William Hooker kept in view were three in number, viz.:

(I) To make of Kew a pleasure ground which would stimulate the interest of the general public in the vegetable kingdom and its products.

(2) To encourage and render assistance to scientific botanists, travelers, merchants and manufacturers.

(3) To train plant collectors and gardeners for home, Colonial and foreign service.

With the first of these we are only slightly concerned in the present paper, and only indirectly with the third, but the second is of the greatest interest, inasmuch as Kew has become the fountainhead of information on medicinal plants in this country.

The ramifications of each of these groups, however, have become so numerous, and the details of their varied developments so intri- 
cate, that it will be conducive to clearness at this stage to subdivide the matter under the following heads:

The extension of the gardens, with special reference to the collections growing out of doors.

The Plant Houses.

The Museums of Economic Botany, the Jodrell Laboratory and the Herbarium.

The Administration of Kew and its Work.

THE EXTENSION OF THE GARDENS.

The Botanic Garden, at the beginning of Sir William Hooker's directorate, was but fifteen acres in extent. The first extension of this area took place in I 843 , when about forty-seven acres of the acjoining pleasure grounds were added to it for the formation of an arboretum, and were separated from the pleasure grounds by a wire fence. This addition was at the time considered to be of sufficient extent for the purpose, and preparations were made for carrying out the project, but when the pleasure grounds were placed under the charge of Sir William Hooker by the Commissioners of Woods and Forests, on July 9, I 845, he utilized these for the formation of an arboretum, and the forty-seven acres which had previously been fenced in were made use of for the development of the general collection. In his report to Parliament for I 853, Sir William states that since the pleasure grounds were placed under his charge they have "been laid out primarily as an arboretum for the cultivation of every tree and shrub which will stand the open air in this climate." The Nursery was formed in I 850 .

In the Winter of I 846-47, fifteen more acres were incorporated with the Botanic Garden by the suppression of the Royal Forcing and Kitchen Gardens. To the land thus acquired the herbaceous and grass collections were transferred.

In I 85 I thirteen acres were taken from the Deer Park (see map, Plate I) and added to the Queen's Cottage grounds, an enclosure on the southwestern corner of the pleasure grounds reserved for the private use of the Crown.

A further acquisition was made in 1853 , when three acres of the piece of ground known as the paddock, and adjoining the former kitchen garden, were added to the northeastern portion of the Botanic Garden. In these a separate collection of British plants and one of hardy medicinal plants were set out. 


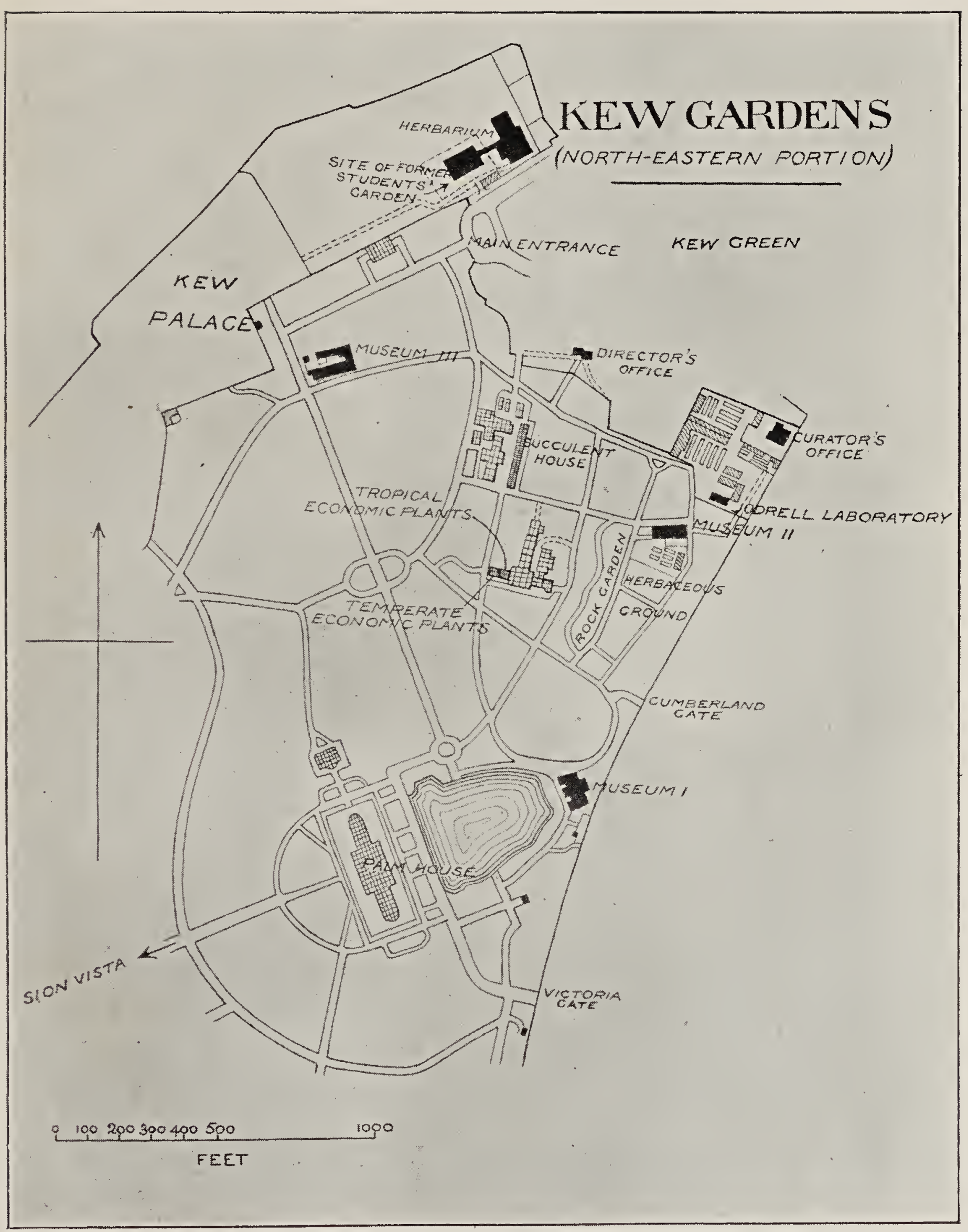

PORTION OF KEW GARDENS KNOWN AS THE "BOTANIC GARDENS" PROPER. NOTE.-The plant houses are indicated by crossed lines, the other buildings by black areas. 

In 1855 Dr. (now Sir) J. D. Hooker, son of Sir William Hooker who was then 70 years of age, was appointed assistant director, and in I 865 , on the death of his father, he succeeded to the directorship without an assistant. The arboretum begun by his predecessor was developed and in a great measure remodelled by him, and we have, so to speak, an index of its increasing importance from his annual reports; thus, we find in the report for $187 \mathrm{r}$ that the heading "Pleasure Grounds" has been replaced by the "Pleasure Grounds and Arboretum." In the report for I $\$ 72$ this has been further modified to the "Arboretum in the Pleasure Grounds," and in 1878 the transformation is complete, the former expressions having been entirely supplanted by the "Arboretum," which stands alone.

Soon after Dr. Hooker's appointment as director, the medicinal and British collections were done away with, and in 1869 the whole of the herbaceous collection was rearranged, new potting sheds, a seed room, frames, etc., being added to it.

A small students' garden, in which it was permitted to gather specimens, was subsequently made in I 880 on the site of the recently completed wing of the Herbarium building.

In I $875 \mathrm{Mr}$. (now Sir) William Turner Thiselton-Dyer was appointed assistant director, and, on the retirement of Sir J. D. Hooker, in I 885 , became Director, a position which he still holds. Dr. (now Sir) D. Morris was appointed assistant director to Sir W. T. Thiselton-Dyer in I 886 , but, since his subsequent appointment as Commissioner of Agriculture at Barbados in 1898, the post which he formerly occupied has remained unfilled.

During the present director's period of office the principal changes that have taken place are the removal, in I 895 , of the wire fence that used to separate the Botanic Gardens from the Arboretum, ${ }^{1}$ and the surrender to the Kew authorities of the private grounds of the Crown, which were thrown open to the public on May I, I 899. The public path traversing these, however, is railed off from the remainder of the grounds; this being done to avoid disturbing the wild birds that have taken refuge in that retreat. The students' garden has also been abolished, in order to make room for the Herbarium extension.

${ }^{1}$ The position which it occupied is shown by a dark line in the map on the smaller scale (Plate I). The map on the larger scale (Plate X) corresponds roughly to that portion of Kew Gardens known as the Botanic Gardens, although the latter title is now perfectly applicable to the whole of them. 
Before proceeding with the description of the Arboretum and Botanic Gardens a few additional historical facts connected with these will be noted. The Botanic Gardens, at the time of Sir Wm. Hooker's appointment to the directorate, included the remains of an old Arboretum which had been begun from 70 to 80 years previously. The disintegration of that Arboretum dates from I 830 , when the boundary wall dividing the gardens from the public road leading to Brentford Ferry was removed. As the trees were thus deprived of the protection which this wall had afforded, many of them were blown down, others have since perished from old age and decay, and the few remaining ones, growing near the main entrance on Kew Green, are of no interest to us.

One the most, if not the most, considerable collection of trees is the Pinetum, brought to its present high level of excellence by the former Director, Sir J. D. Hooker. It surrounds the nursery on the south side of the lake, skirts the Queen's Cottage grounds on its western boundary, and is traversed by a grass walk known as the "Cedar Vista" (see Plate I). The collection contains a large number of American conifers, and the plants are so arranged that the Old World species are placed opposite to the American species of the same genera.

Here are to be found the poisonous yew (Taxus baccata, I.) and its varieties; the four junipers yielding products used in medicine, viz.: Juniperus Sabina, L., or savin, and the red cedar (Juniperus Virginiana, L.), from which an analogous drug is obtained, Juniperus communis, I., from which the juniper berries and oil of juniper of commerce are derived, and Juniperus Oxycedrus, I., from the wood of which, and probably from that of other species, "Huile de Cade" is prepared by destructive distillation ; the common spruce (Picea excelsa, Link.), and its numerous varieties, from which Burgundy pitch is collected by making incisions into the wood; the larcli (Larix Europca, DC.), whose bark is occasionally used in medicine, and on which grows the white agaric of Continental Pharmacopoias, it is also the source of Venice turpentine; Abies balsamea, Mill., the "Balsam Fir" or "Balm of Gilead," from which Canada turpentine or Canada balsam is obtained by incisicn; Pinus Laricio, Poir., and varieties, Pinus sylvestris, L., Pinus Pinaster, Soland., and others, from wlich European turpentine and Galipot are obtained; and the North American species, Pimus palustris, Mill., Pinus Tada, L., etc., which are the sources of most of the resin of commerce, of American turpentine, and of common frankincense.

On the east of the Pinetum, and flanking the Pagoda Vista (see Plate I) on each side, the collections consist mostly of shrubs, as, for instance, representatives of the genera Berberis, Rhus, Rubus, 


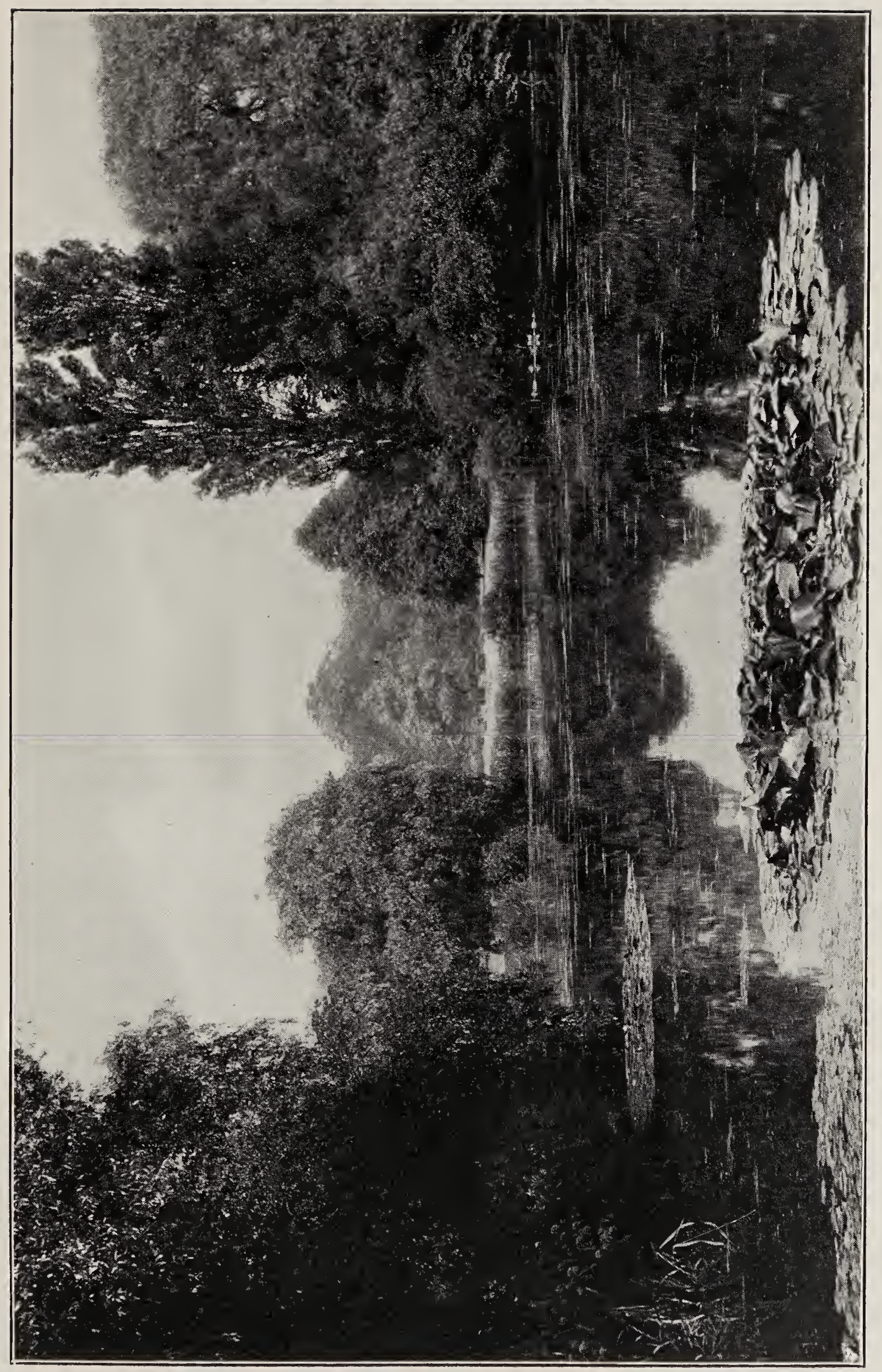

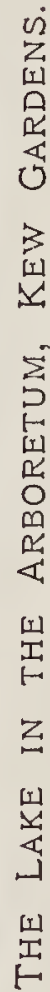



Cratagus, Rhammus, etc., while on the north of the lake and Pinetum, and west of the Botanic Gardens, the collections consist mostly of trees, such as oaks, chestnuts, elms and poplars. The willows, with the exception of the alpine species, are grown on the borders of the lake.

Among the many plants of interest to the pharmacist in these sections of the Arboretum are the following: Berberis aquifolium, Pursh., B. nervosa, Pursh., and $B$. repens, Lindl., sources of Oregon grape root; Berberis vulgaris, L., and its numerous forms and varieties, from which the barberry bark of herbalists is obtained; Tilia heterophylla, Vent., and $T$.platyphyllos, Scop., whose inflorescences with attached bracts, known as "Linden Elooms" (French, "Fleurs de Tilleul") have long been used on the Continent in the form of infusion; Xanthoxylum Americanum, Mill., one of the species yiclding the prickly ash bark of the U.S.P.; Rhammus Californicus, Eschsch., the source of the "Cascara Sagrada," or Sacred Bark, of the Spanish settlers in California, $R$. Purstianus, DC., from which the drug of commerce is derived, and $R$. Frangula, L., and $R$. catharticus, L., Old World species yielding respectively alder buckthorn bark and buckthorn berries ("Frits de Nerprun" of the French Codex) ; Rhus glabra, L., the sumach whose fruits are official in the U.S.P.; Rhus toxicodendron, L., or poison oak ; Pistacia Lentiscus, L., fron which gum mastich is collected; Cytisus scoparius, L., or broom; Robinia Pseudacacia, L., from the bark of which a poisonous proteid has been extracted ; Cassia Marylandica, L., the "Wild American Senna," with leaves resembling Suez senna from Cassia obovata, Collad.; Prunus Amygdalus, Stokes, or almond tree, and $P$. communis, Hudson, cultivated for their seed-kernels and fruits respectively, as also Prunus Laurocevasus, L., for its leaves, whilst $F$. serotina Ehrh. yields the wild cherry or Virginian prune bark of the pharmacopœias; the three representatives of the genus Rosa, R. canina, L. (and its numerous varieties), $R$. damascena, Miller, and $R$. Gallica, L., sources respectively of hips, otto of rose, and red-rose petals; Cydonia vulgaris, Pers., represented in pharmacy by its mucilaginous seeds ; Hamamelis Virginica, I., whose leaves and bark both figure in the British Pharmacopœia; Sambucus Canadensis, I., S. nigra, I., and varieties, whose flowers are used for the preparation of elder-flower water; Viburnum opulus, L., the source of cranipbark; Arctostaphylos Uva-ursi, Spreng., or bearberry, whose leaves are official in most pharmacopœias, and Gaultheria procumbens, I., of the same family, from the leaves of which oil of wintergreen is distilled; Fraxinus Ormus, L., the manva ash; Solanum Dulcamara, I., whose stems were still retained in the U.S.P. of IS9o; Rosmarinus officinalis, L., or rosemary; Sassafras officinale, Nees, well known for the fragrant bark and wood of its root; Ulmus campestris, I., the common elm of the Old World, and the American slippery elm (Ulmus fulva, Mich.), both represented in commerce by their barks; Juglans cinerea, L., the American "Butternut"; Betula lenta, I.., from whose bark is distilled an oil which is closely related to oil of wintergreen; Quevcus alba, L., Q.pedunculata, Ehrh., and its numerous varieties, yielding astringent barks, and $Q$. Suber, L., the cork oak; Castanea dentata, Borkh., whose leaves are used for the preparation of a fluid extract; Smilax 
China, L., formerly used for its root, now almost entirely supplanted by sarsa. parilla; Salix alba, L., S. discolor, Muh1., S. fragilis, L., S. nigra, Marsh., S. purpurea, L., and S. rubra, Huds., in the collection of willows, which have all at some time claimed the pharmacist's attention.

The hardy herbaceous plants are grown in the Herbaceous Ground, which is situated on the northeastern corner of the Botanic Gardens, between the Jodrell Laboratcry and the Cumberland Gate, and bounded on the east by the Richmond Road and on the west by the Rock Garden. The plants are set out in parallel beds and are arranged according to their natural orders, Bentham and Hooker's classification being followed. There is also a separate collection of hardy medicinal plants in this section, but this will be considered together with the general collection. As the number of plants in this collection is very large, it will only be necessary to select a few natural orders to indicate its scope, and the following six will, accordingly, be briefly dealt with: Ramunculacee, Papaveracee, Umbellifere, Composita, Solanacer, and Liliacea.

Ranunculace s.-Aconitum Napellus, L., the official aconite, A. ferox, Wall., Indian Bish, and $A$. Fischeri, Reichb., Japanese aconite; Adonis astivalis, L., $A$. autumnalis, L., and $A$. vemalis, L., all recognized by the Italian Pharmacopoia; Anemone Hepatica, L., a North American species occasionally used in decoction, and $A$.pratensis, L., and $A$. Pulsatilla, L., the pulsatilla of the homeopaths; Cimicifuga racemosa, L., the North American black suakeroot; the bitter tonic goldthread (Coptis trifolia, Salisb.), containing berberine; Delphinimm Consolida., I., yielding acrid seeds, and the betterknown D. Staphisagria, L., the source of stavesacre seeds of commerce; Helleborus niger, I., the black hellebore or Christmas Rose; Hydrastis Canadensis, I., or golden sea1; Nigella Damascena, I., and Nigella sativa, L., with acrid seeds now rarely used; Ranunculus Ficaria, I., the pilewort, whose roots were used by the old herbalists to cure hemorrhoids by signature.

PAPAVERACE, I:-Chelidonium majus, I., celandine, upon which a considerable amount of work has been done of recent years by American pharmacists; Papaver Rhocas, I., the red poppy, and $P$. somifermm, L., the opium poppy; and Sanguinaria Canadensis, I., the North American bloodroot.

UMBELIIFER E - - Many of these are more especially known to pharmacists on account of their fruits, and others by reason of the gum-resins which they yield. The following from among the former are grown at Kew: Apium graveolens, I., celery; Archangelica officinalis, I., or "Angélique officinale"; Carum Carvi, I., caraway, and C. Petroselinum, Benth. et Hook. f., parsley; Conium maculatum, L., hemlock; Coriandrum sativum, I., coriander; Cuminum Cyminum, I., cummin; Enanthe Phellandrium, Lam., tle "Pheilandrie aquatique" of the French Codex; Peucedanum graveolens, Benth., dill; and Pimpinella Anisum, I., or anise. The umbelliferous plants yielding resins or gum-resins are represented by Dorema Ammoniacum, D. Don., the plant from which anmoniacum is obtained; Ferula Asafatida, L., and Ferula 
Narthex, Boiss., the sources of gum asafetida; Ferula Galbaniflua, Boiss. \& Buhse, the Galbanum Plant; Opoponax Chironium, Koch., supposed to yield the almost obsolete drug, opoponax; and Thapsia Garganica, L., from which "Résine de Thapsia" is extracted. With the exception of Hydrocotyle Asiatica, L., of which the whole plant is used, and of hemlock leaves, the other drugs derived from this natural order are roots, including one rhizome; the plants yielding them are: Daucus Carota, L., carrot, the root-pulp of which is used as an application for scalds and burns; Ferula Sumbul, Hook. f.; Laserpitium latifolium, L., or white gentian ; Levisticum officinale, Koch., or lovage; and PeucedanumOstruthium, Koch., the source of "Rhizome d'Impératoire."

Compositex.-Achillea Millefolium, L., the yarrow of herbalists; Anacyclus Pyrethrum, DC., pellitory; Anthemis nobilis, L., chamomile, and the closely related $A$. Cotula, L., or Mayweed; Amica montana, L., whose rhizomes and flowers are both used ; Artemisia Absinthinm, L., "Absinthe" or wormwood, and $A$. maritima, L., of which the variety Stechmanniana yields the santonica or "Wormseed" of commerce ; Calendula officinalis, L., marigold, and Carthamus tinctorius, L., safflower, whose florets contain coloring matter and have been used to adulterate saffron; Chrysanthemum carneum, Steud., one of the sources of Persian insect flowers, and $C$. Parthenium, Bernh., or feverfew, a substitute of chamomile; Cnicus benedictus, L. (Carbenia benedicta, Adans.), the Blessed Thistle; Cichorium Intybus, L., chicory; Erigeron Canadensis, L., and Evigeron Philadelphicus, L., both known in the United States as fleabane or scabious ; Eupatorium perfoliatum, I., boneset; Helenium autumnale, I., or sneezewort ; Grindelia squarrosa, Dunal ; Inula Helenium, L., elecampane; Lactuca virosa, I., the source of lactucarium, and one of the few composites in which a well-defined alkaloid (hyoscyamine) has been found; Senecio vulgaris, L., groundsel, which still figures among the drugs of the French Codex ; Tanacetum vulgare, I., the tansy of herbalists ; Taraxacum officinale, Weber, dandelion; and 7ussilago Farfara, L., or coltsfoot.

SOLANACEA. - The most important plants of this collection are those which yield the mydriatic alkaloids, viz.: Atropa Belladonna, L.; Datura fastuosa, L., and $D$. Metel, L., official in the Colonial and Indian Addendum of the British Pharmacopœia, and D. Stramonium, L.; Hyoscyamus albus, L., $H$. muticus, L., and H. niger, L.; and Scopolia Camiolica, Jacq. Four other plants of this order that are represented, are of comparatively little importance in medicine-they are: Mandragora officinarum, L., mandrake, formerly of great repute with the disciples of the doctrine of signatures, because of the similarity to the human form which some of its roots assume; Nicotiana Tabacum, L.; Solanum nigrum, L., and S. tuberosum, L., the potato, both still retained in the French Codex, the former for the preparation of a medicinal oil, and the latter as the source of potato starch, used in enemata, poultices, and for making a nutrient broth.

LILIACE正.-Although the drug-producing plants of this order are not numerous, a few of them are of the greatest importance. The following are grown out of doors in the Herbaceous collection at Kew : Colchicum autumnale, L.; Convallaria majalis, L. ; Polygonatum officinale, All., and the closely related North American species, $P$. biflorum, Ell., whose rhizomes, formerly held in great esteem by the adherents of the doctrine of signatures, are now 
seldom used; Urginea Scilia, L., the Squill of the Pharmacopœias; Trillium evectum, Lo, with acrid rhizomes now never used in medicine; Veratrum album, L., white hellebore, and the North American species, Veratrum viride, Ait., both yielding rhizomes possessing similar properties to each other.

\section{THE PLANT HOUSES.}

With the exception of the Temperate House, which is situated in the Arboretum, facing the Pinetum, all the plant houses are located in the Botanic Gardens (see Plate X). Five of them, viz., the Succulent House, the Temperate and the Tropical Economic Houses, the Palm House, and the Temperate House, are devoted, at least in part, to the culture of medicinal plants.

The Succulent House (see Plate XII) was completed in I 855 , in Sir William Hooker's term of office, and took the place of two old lean-to houses of about a third the area. It was newly roofed last year (1904). The collection of succulents, already considerable as early as I 768, was much increased by the labors of Francis Masson, already mentioned as the first botanical collector sent out from Kew, and by another Kew collector; James Bowie, who was sent to the Cape of Good Hope in ISI7, and remained there five years; the collection was also much enriched in 1887 by purchases from the Peacock collection.

The most important medicinal plants in the Succulent House are the numerous species of Aloe from which aloes is obtained; among these may be mentioned Aloe Perryi, Baker, one of the plants from which Socotrine aloes is known to be derived, $A$. ferox, Mill., which yields a part, at least, of Cape aloes, and $A$. Chinensis, Baker, to which Barbados or Curacoa aloes has been referred; other species are doubtless used for the production of aloes, but nothing very definite is known on the subject. Other plants of interest in this collection are: Cereus grandiflorus, Mill., whose flowers are known in commerce as "Cactus Grandiflorus"; Euphorbia resiniferd, Berg., the source of Euphorbium; Nopalea coccinellifera, Salm-Dyck (Opuntia cochinilliferc, Mill.), which, together with other species of the same genus, serve as food for the cochineal insect; and Xanthorrhac hastilis, R. Br., the source of the resin known in commerce as grasstree gum or gum acroides.

The two Economic houses form part of a "range" constructed in the form of a $\mathbf{T}$ (see Plate $\mathrm{X}$ ). The heating of this range is so devised that the highest temperature is attained near the junction of the bars of the "T," the houses becoming cooler towards the extremities. This "New Range," as it is called, was erected in I 869, shortly after the opening of the "Kew Gardens" railroad station. The Director's report

${ }^{1}$ Solander is frequently cited instead of Aiton as the authority for this name. For explanation see footnote on p. I2. 


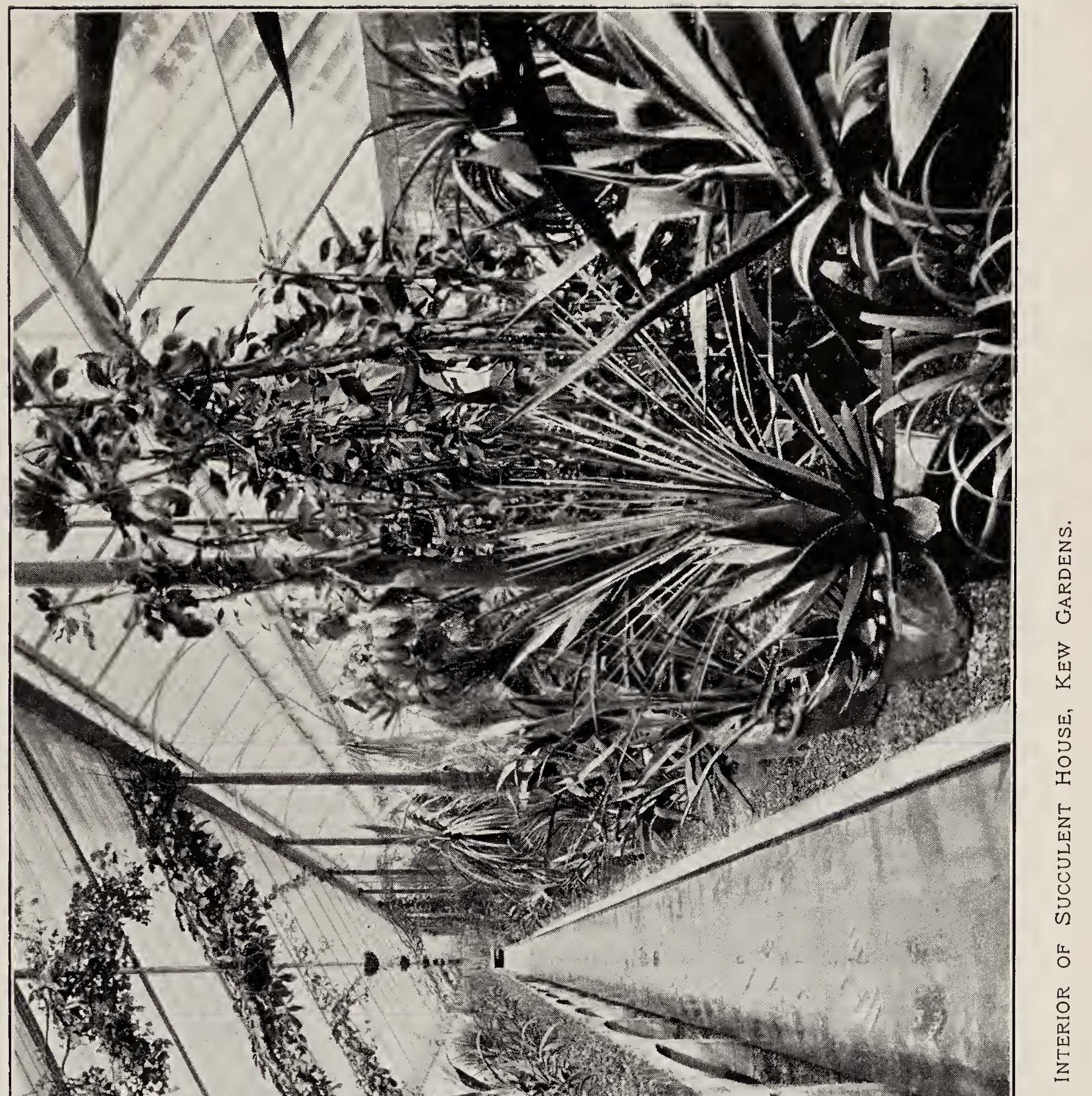



to Parliament for I88 I contains a list of the economic plants growing at Kew at that time, and, in connection with this list, the Director stated that when the Economic houses were built "some of the most conspicuous and now widely spread and even commercially important of the plants for which they were intended, were absolutely unknown in Europe, or known only as botanical curiosities of no known use to mankind; such are some of the cinchonas, of the American and African rubbers, the Liberian coffee, etc." In I 899 these houses were rebuilt as they exist at present. It had been one of Sir William Hooker's main objects, from the first, to pay special attention to the study and cultivation of economic plants, including such as are used in medicine, but it was not until I 865 that any attempt was made to bring them together, when an old house, known as the "Victoria House," was set aside by Sir Joseph Hooker for the purpose. On the completion of the new range this old Victoria House was demolished.

The following is a list of the medicinal plants growing in the Economic houses when I last visited them:

In the tropical house:-Abrus precatorius, L., from which are obtained the poisonous Jequirity seeds used in ophthalmic practice ; Acacia Catechu, Willd., the source of Black Catechu or Cutch; Aggle Marmelos, Correa, whose fruit is used i11 India for the treatment of dysentery; Anamirta Cocculus, Wight et Arn., from whose fruits, known in commerce as "Cocculus Indicus," picrotoxine is prepared; Antiaris toxicaria, Lesch., the Upas tree of Java, with a poisonous latex; Bixa Orellana, L., the seeds of which are used for the preparation of Annatto; Butea frondosa, Roxb., source of Bengal Kino; Canella alba, Murr.; Cephaelis Ipecacuanha, Rich., from which the Ipecacuanha root of the Pharmacopœias is obtained; Cimnamomum Cassia, Blume, or Chinese Cassia; Citrus Aurantium, L., C. medica, I., the Citron tree, and C. Limetta, or Sweet Lime, from which lime juice is prepared; Cissampelos Pareira, L., for a long time considered to be the source of Pareira Brava, and the root of which is now admitted into the Colonial and Indian Addendum of the B. P.; Coffec Arabica, L, and the more vigorous C. Liberica, Hiern, which has, consequently, been the subject of much cultural experiment; Cola acuminata, S. and E., from which Kola Nuts are obtained; Copaifera officinalis, L., a probable source of Copaiba ; Curcima longa, L., or Turmeric ; Derris elliptica. Benth., an East Indian fish poison ; Elettaria Cardamomum, Maton, the plant which yields official Cardamoms, and the closely related Amomum Melegueta, Rosc., source of Grains of Paradise; Erythrophloum Guineense, G. Don, a Tropical African tree whose bark, known in commerce as Sassy Bark, is used by the natives as an ordeal poison ; two Cocas, viz., Erythroxylon Coca, Lam., and E. Coca var. Spruceanum, Burck; Guaiacum officinale, I., and Guaiacum sanctum, L., the trees from which "Lignum vite" and guaiacum resin are 
obtained; Marsdenia Cundurango, Nicholls, source of Cundurango bark ; Myristica fragrans, Houtt., the Nutmeg tree; Myroxylon Pereirce, Klotz. from the bark of which Balsam of Peru is obtained; Nicotiana Tabacum, L.; Paullinia Cupana, H. B. K., whose seeds, roasted and ground into a paste with water, constitute the guarana of commerce; Picrena excelsa, Lindl., or Janaica Quassia; Pilocarpus pennatifolius, Lem., whose leaflets are known in commerce as Paraguay Jaborandi; Pimenta acris, Kostel., the volatile oil of which is used in making Bay Rum, and $P$. officinalis, Lindl., whose fruits constitute Allspice ; Piper Betle, L., whose leaves are official in the B. P. Indiarand Colonial Addendum, P. Cubeba, L., the Cubeb plant, P. iongum, L., or Long Pepper, and P.nigrum, L., the source of Black and White Peppers; Quassia amara, L., or Surinam Quassia; Strophanthus hispidus, DC., whose seeds, together with those of other species of Strophanthus, have been used in heart disease; Tamarindus Indica, L.; Theobroma Cacao, L., the source of Cocoa; Toluifera Pereirce, Baillon (Myroxylon Toluiferum, H. B. K.), the tree yielding Balsam of Tolu; and several plants yielding india.rubber.

The following, not previously mentioned, were noted in the temperate Economic house : Acacia Arabica, Willd, whose bark is official in the Colonial and Indian Addendum of the B.P., as is also that of Alstonia scholaris, R.Br.; Canna edulis, Ker., the source of Queensland arrowroot; Cassia obovata Collad., whose leaflets are known as Suez senna ; Ceratonia Siliqua, L., whose fruits, known as "Locust Beans," are official in the French Codex under the name of "Caroubes"; Cinchona Calisaya, Wedd., C. Ledgeriana, MIoens, C. Pahudiana, How., and C.officinalis, L.; Cinnamomum Camphora, Nees, the tree yielding camphor, and $C$. Zeylanicum, Breyne, the cinnamon tree; Citrus Aurantium, L., var. Bergamia, or bergamot; Croton Tiglium, L., from the seeds of which Croton oil is obtained; Dracana Draco, I., the source of dragon's blood in tears; Eucalyptus Amygdalina, Labill., and E. citriodora, Hook., from the leaves of which volatile oils are distilled; Ilex Paraguayensis, Lamb., whose leaves are known as "Maté" and contain caffeine; Illicium verum, Hook. f., with aromatic fruits yielding oil of anise by distillation, and I. religiosum, S. \& Z., a poisonous Japanese species; Melalenca Lencadendron, L., or Cajeput; Olea Europeea, I., the olive; Peumus Boldus, Molina, or Boldo; Phonix dactylifera, I., or date palm; Quillaja Saponaria, Molina, the source of soap.bark; and Zizyphus Jujuba, L., whose fruit-pulp is used in the preparation of the "Pate de Jujube" of the French Codex.

The Palm House.-This building was completed in I 848 , and the collections of palms and other tropical plants that had previously ocupied the house erected by William IV, near the main gate, were transferred to it. The heating arrangements at first were unsatisfactory, but in I 877 these were made efficient by the installation of a perfected arrangement of boilers. The arrangement of the plants is, to a considerable extent, a geographical one, the smaller specimens on the benches skirting the sides being grouped together according to the continents of which they are natives, Tropical 



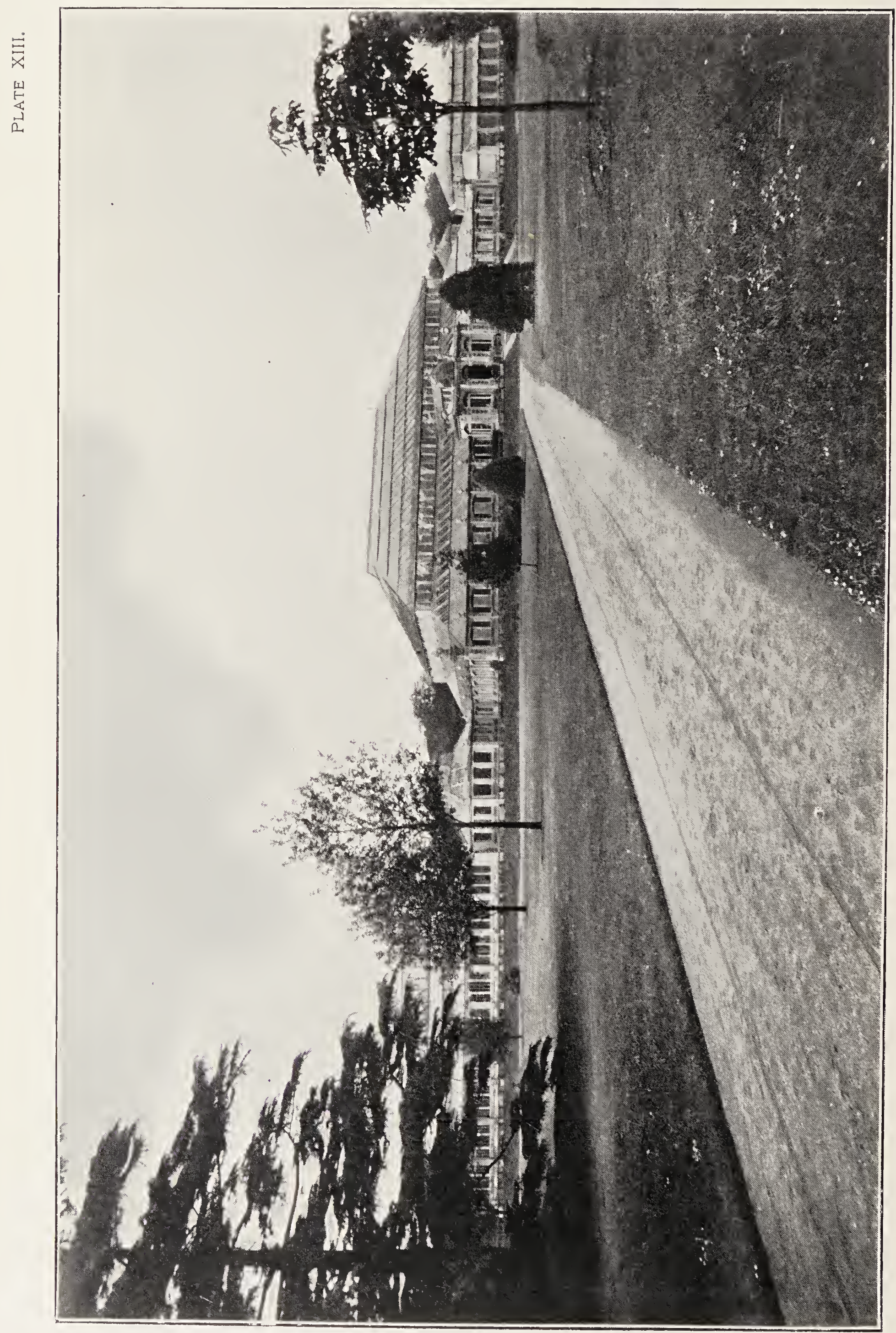

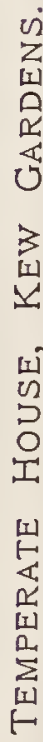




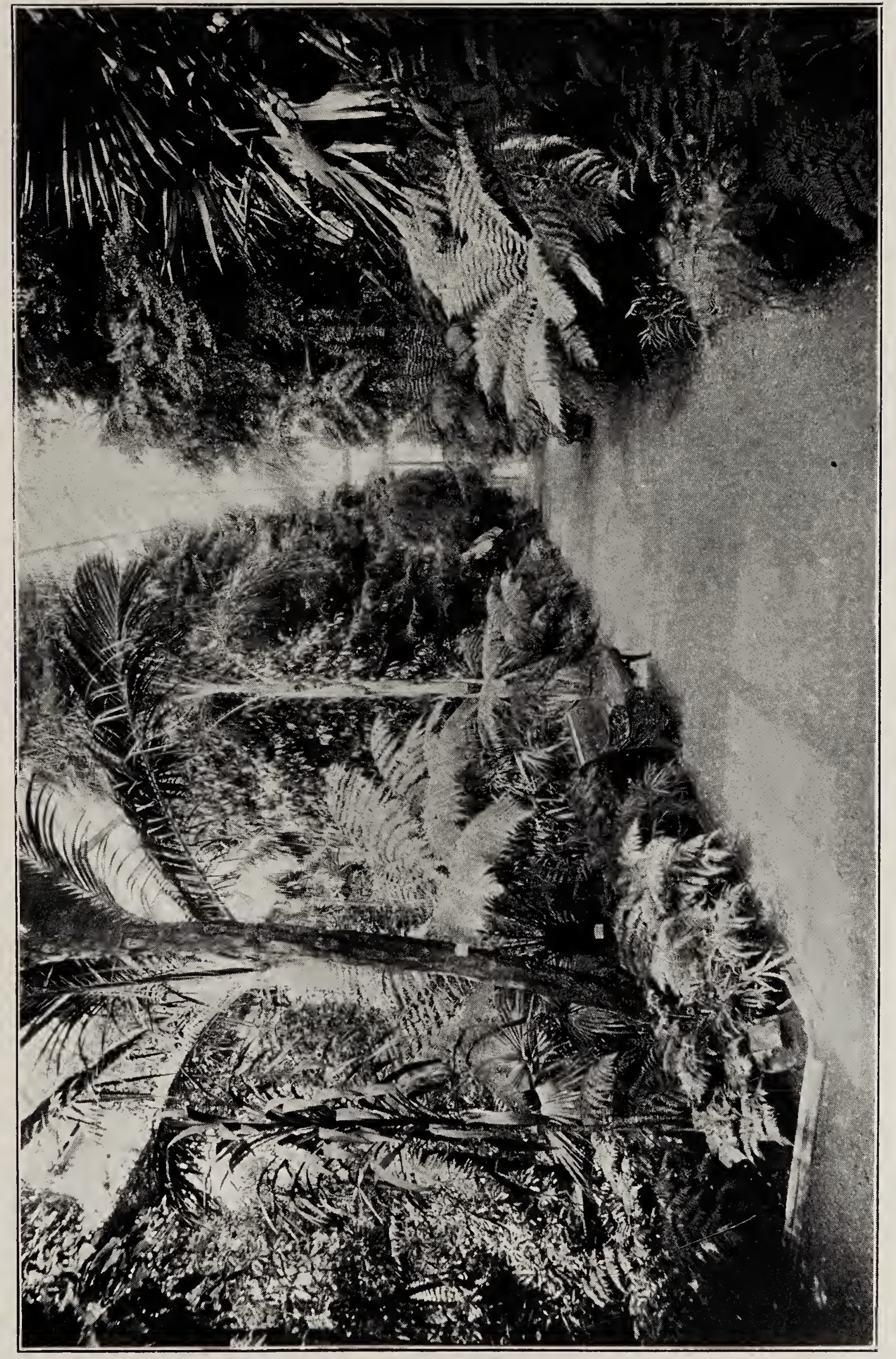

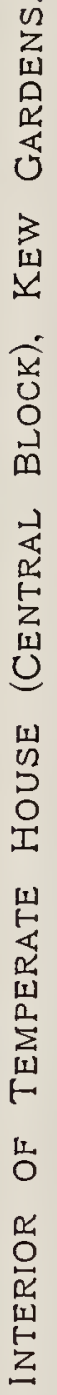



Asiatic, Tropical American, and Tropical African plants, for instance, being successively placed together on the benches. The larger plants growing in the central beds follow no very definite arrangement, but are largely grouped for convenience or effect. Such medicinal plants as are grown in the Palm House are scattered throughout the collections; many of them have already been enumerated in connection with the contents of the Tropical Economic House; but the specimens in the Palm House, owing to greater space, are finer, as, for instance, Myristica fragrans, Houtt. ; Theobroma Cacao, L., and Strophanthus hispidus, DC.

Among the plants not already enumerated, the following yield products of interest to pharmacists : Areca Catechu, L., the areca-nut palm ; Carica Papaya, L., or papaw, from the latex of which papain is prepared ; Cocos mucifera, L., the cocoanut palm; Elais Guineensis, Jacq., whose fruits yield palm oil; Eugenia caryophyllata, Thunb., whose dried flower-buds are known as "cloves;" Gossypium herbaceum, L, G. arboreum, L., Old World species of the cotton plant, and G. Barbadense, L., the source of American cotton; Hcematoxylon Campechianum, L., or logwood; Musa sapientum, L., the banana, and its variety, Paradisiaca, the plantain; Piper angustifolium, R. \& P., whose leaves are known in commerce as "matico," and P. methysticum, Forst., whose rhizome is official in the Colonial and Indian Addendum of the B.P. under the name of "kava-kava rhizome;" Smilax ornata, Hook, f., the plant whose root constitutes the "Jamaica" sarsaparilla of the pharmacopœias; Saccharum officinarum, L., the sugar cane; Strychnos Ignatii, Berg., and S. Nux vomica, L.

The Temperate House.-This building consists of several disa tinct divisions, as shown in the accompanying plan :

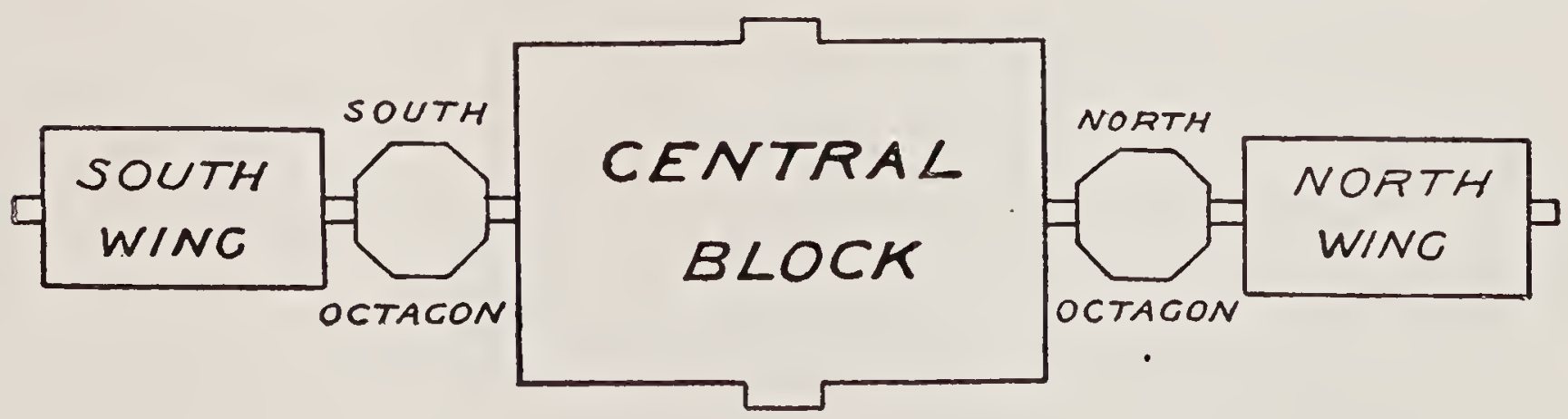

The two octagons were completed in I $86 \mathrm{I}$ and the central block in 1862. The north wing was added in 1897 and the south wing in I 899. The principal feature of the central block is the Australian collection which formerly occupied the old Orangery (now Museum III) and a lean-to house located immediately to the left of the present Succulent House. This collection was subsequently removed to the 
conservatory near the main gate, and finally deposited in the present building in I862, where it has since remained. There are few plants of interest here that have not already been mentioned, but reference must be made to the collection of Eucalypti, among which Eucalyptus globulus, Labill., the species yielding official Eucalyptus oil, is represented. Quillaja Saponaria, Molina, the soap-bark tree, and Olea Europaa, L., of considerable size, are also grown in this collection. The northern octagon is used principally for the display of ornamental plants and the southern as an orangery. The north wing is devoted to the cultivation of rhododendrons and camellias, while the south wing, heated to a temperature intermediate between that of the remainder of the building and of the Palm House, contains numerous Mexican plants and is hence known as the Mexican House. It is, however, more especially of interest to us on account of a number of large specimens of medicinal plants for which its temperature is well adapted. Especially prominent among these are the cinchonas and plants producing india-rubber.

\section{THE MUSEUMS, LABORATORY, AND HERBARIUM.}

Although a detailed description of the above does not fall within the limits of this paper, no account of Kew would be complete without some reference to these essential adjuncts of the gardens, and a rapid enumeration of the salient facts connected with them will accordingly be given.

The idea of forming a museum for the reception of drugs and other economic products derived from the vegetable kingdom, originated with Sir William Hooker, who, in I 847 , adapted a brick structure which had previously formed part of the Royal Kitchen Gardens, and converted it into a museum. This, together with a small west wing added in I88I, constitutes the present Museum II (see Plate $\mathrm{X}$ ); it is now devoted to vegetable products derived from monocotyledons and cryptogams.

Museum I (see Plates VIII and X) was opened to the public in I 857. It contains the dicotyledonous and gymnospermous collections, which were removed to it in that year. The extension on the north side was added in I $88 \mathrm{r}$ from a grant made by the India office.

Museum III (see Plates V and X) is devoted to Timbers. The building was erected in I 76 I as an orangery for the Princess Augusta. It was subsequently used as an Australian House, until opened as. 


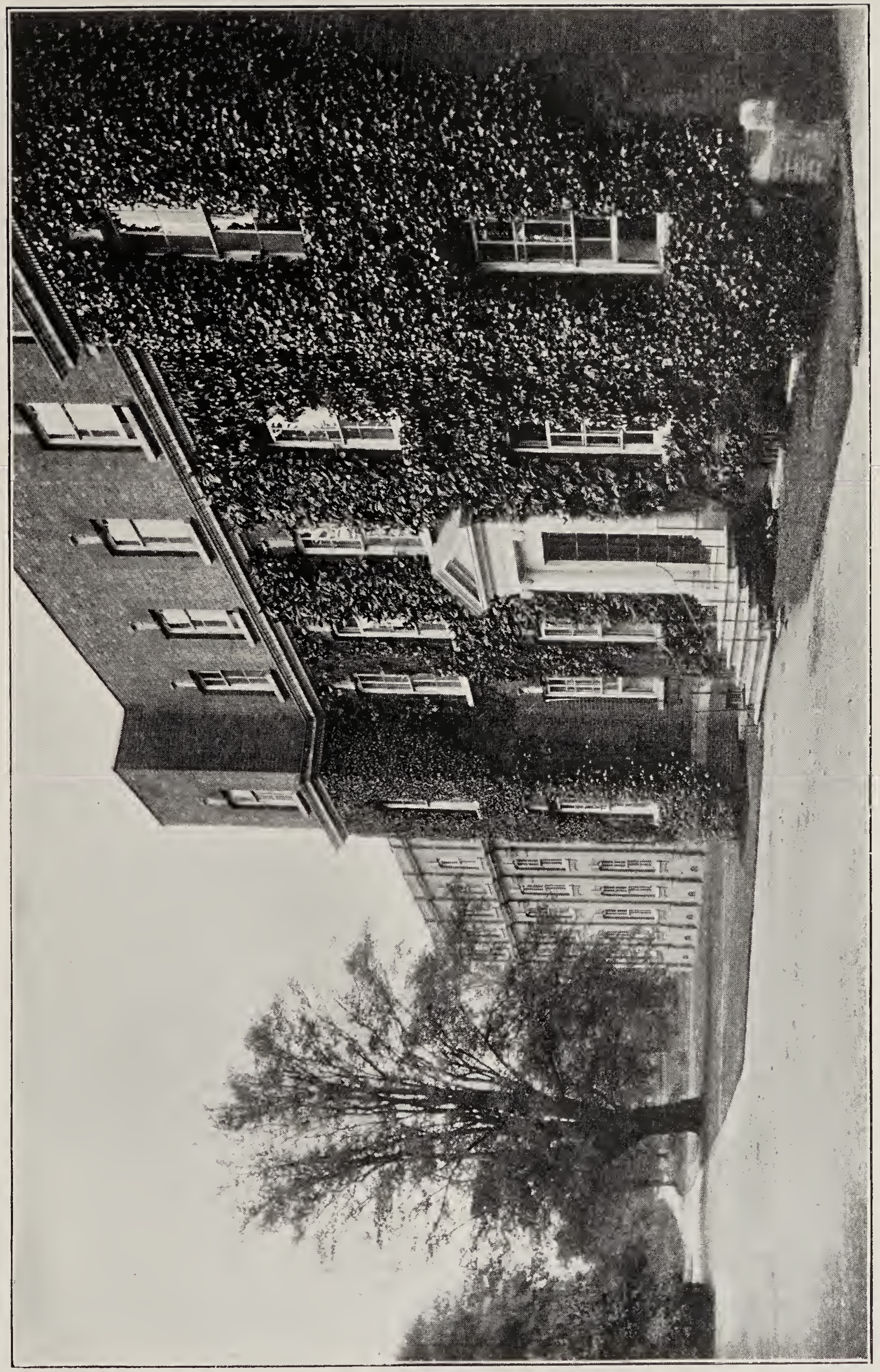

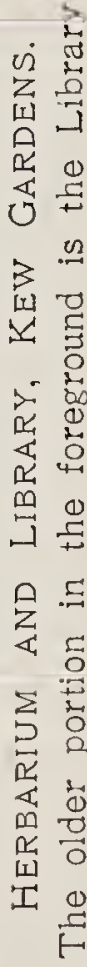



a Timber Museum in 1863 . The collections originated with the exhibits of Colonial timbers from the London International Exhibition of I 862, and were greatly increased, in I878, by the gift to Kew of a rich collection of timber products from the Indian Government, and of a still more extensive one from the India Office in I880. The specimens in Museums No. I and No. II are arranged according to natural orders (Bentham \& Hooker), and maps are placed in the cases containing them, indicating their geographical sources. In the Timber Museum the collections are arranged geographically. The total number of economic specimens exhibited, other than woods, is about 20,000 . The wood specimens (including the timber collections in Museum III, and the smaller wood specimens in the other two museums) number 6,500. A large proportion of these specimens are drugs, but the actual figures are not available.

In I880, the "North" gallery was completed. This building, presented to the nation by Miss Marianne North, and containing an extensive collection of paintings of tropical and sub-tropical plants executed by her, was opened to the public in July, I 882.

The Laboratory (see Plate X), founded by the late J. T. Phillips Jodrell, and hence known as the Jodrell Laboratory, was commenced in I 875 and completed in I876. It is used primarily for research purposes, and the following workers, among others, have conducted investigations in it: Burdon-Sanderson, Romanes, Church, LauderBrunton, Hugo Müller (chemical constituents of the leaves of Sabal umbraculifera), Rev. R. Abbay, F. Darwin, Marshall Ward, Pfitzer, Bower, Cross \& Bevan (on cellulose), W. Gardiner, E. Schunck (on chlorophyll), Lord Avebury, G. Massee (on fungal plant diseases), De Wevre (on cubebs, etc.), J. R. Green (on diastase; and other researches), and D. H. Scott (the present Honorary Keeper).

The Herbarium and Library (see Plates X and XV).-It will be remembered that towards the close of Sir Joseph Banks' life, a house, called Hunter House-from the name of its owner, Robert Hunter, a successful man of business who had settled at Kew-was purchased by George III, and added to the Royal property. At the instance of Sir Joseph Banks it was determined to devote this to the accommodation of a botanical library and herbarium, and one of the rooms was fitted up with book-shelves as a commencement towards carrying out this project. At Sir Joseph Banks' death, however, the plan was abandoned, and the house remained empty 
until the reign of William IV, who granted it to the Duchess of Cumberland for life. The Duke of Cumberland, who subsequently succeeded to the throne of Hanover, resided in it occasionally, and it accordingly became known as Hanover House. After his death, Hanover House remained unoccupied. When Sir William Hooker took charge of the Gardens at Kew, they were unprovided with any public herbarium or scientific library, the collections that had previously existed there having been dismembered before his appointment, as has already been noted. Sir William Hooker, however, possessed an extensive herbarium and library of his own, which he placed at the disposal of the public, the Government renting a neighboring house, afterwards known as "West Park," for their accommodation, and as a residence for the director. In 1852 , though still remaining his private property, the director's herbarium and part of his library were removed to Hanover House. After his death in I 865 , his herbarium and library were purchased by the Government at a valuation and added to the public herbarium at Kew, which had been founded in I 854 , when Bentham presented his extensive private collection of plants and botanical library to the nation.

The older portion constituting the herbarium building proper was erected in 1877 to take the place of the northern portion of "Hanover House," the oldest portion of all, fronting Kew Green, being now devoted to the library. The west wing, erected on the site of the former students' garden, was completed in 1903.

Since the time of Sir W. J. Hooker's appointment to the directorate, the herbarium has received almost all the collections made by Government expeditions, and it has also been the chief recipient in this country of contributions from British and foreign travellers, as well as from Continental museums, so that its collections now consist of upwards of two million specimens. The expansion of the library has kept pace with that of the herbarium, and it now consists of nearly 20,000 volumes. Of these, twelve hundred are kept in a separate building for the use of the gardeners, and the keeper of the museums has about 700 works of reference in his office.

\section{THE ADMINISTRATION OF KEW AND ITS IVORK.}

The government of Kew is, so to speak, a dual function. In all administrative matters the Director is subordinate to the Board of 
Agriculture. The direction and organization of the scientific work of the establishment, on the other hand, devolve upon the Director, whose powers in this direction are absolute. Previous to the deliberations of the Royal Commission on Scientific Instruction and the Advancement of Science, generally known as the "Devonshire Commission" (I87I-1875), the functions of the Director had not been clearly defined, but in July, I 872 , the relations of the Director of Kew to the First Commissioner of Works and Public Buildings were defined as above by a Treasury minute. The Government department has since then undergone reorganization, but its relations to Kew have not been materially altered. It has already been stated that when Kew was converted into a public institution it was placed under the department of Woods and Forests. This Government department was instituted in I 810 , and until I 83 I its constituents were known as "Commissioners of Woods, Forests, and Land Revenues"; they were replaced by the "Commissioners of Woods, Forests, Land Revenues, Works and Buildings" from I 832 to 1850 , and subsequently the department was divided into the "First Commissioner of Works and Public Buildings" and the "Commissioners of Woods, Forests, and Land Revenues," Kew falling under the former. The Board of Agriculture was established by the act of I 899, and, by an Order in Council of March 28, I903, Kew was transferred to it from the department of the First Commissioner of Works and Public Buildings.

The Director's staff of officers is constituted as follows:

(a) Assistant Director. This post has been irregularly occupied, and is at present unfilled.

(b) The Curator of the Gardens, who has charge of the living collections. There are two assistant curators.

(c) The Keeper of the Herbarium and Library (eight assistants).

(d) The Keeper of the Museums (one assistant).

(e) The Honorary Keeper of the Jodrell Laboratory, who is, in a sense, its director, the workers in this laboratory not being, as a rule, on the regular staff at Kew. Permission from the Director of Kew is, however, an essential prerequisite for admission.

The heads of the departments $(b),(c)$, and $(d)$ are directly responsible to the Director for the work done under their care. The organization of the scientific work of Kew is hence of the simplest kind, and resolves itself into departmental government, the depart- 
mental chiefs being, in turn, severally and individually dependent upon the Director for their instructions.

In considering the nature of the work done at Kew it will be necessary to adopt a method of rigid selection. A short account will, therefore, be given, in the first place, of the special training provided at Kew for young gardeners, after which the relation with the Colonies will be touched upon, especially with reference to economic plants. Finally, the Kew publications and the facilities enjoyed by scientific workers and others, together with the concomitant results, will be briefly surveyed, in so far as they relate to medicinal plants.

The training of gardeners constitutes the only direct educational work carried on at Kew, but it is of far-reaching importance. Five years' previous experience is required of every candidate for admission. The training consists of practical work and lectures. In the former, the student is taken successively through the various sections of the gardens and houses; the lectures are delivered concurrently by the officers or their assistants. The lectures comprise a course in physics and chemistry, as applied to botany and geology; another in general botany; a third on economic plants and their products; and a fourth on geographical botany. During his stay at Kew, the young gardener has to collect, mount, and name a herbarium of 250 specimens himself; at the end of two years he is granted a Kew certificate, provided that his work has been satisfactory. The great importance of this training lies in the fact that Kew is thereby enabled to act as a feeder for the staffs of Colonial and home gardens and other botanical institutions.

The relation of Kew to the Colonies is somewhat peculiar, inasmuch as the botanical establishments of these are in touch with the Colonial office, and do not fall within the jurisdiction of the Board of Agriculture as Kew does. The connection between the two is consequently not very apparent at first sight, but Kew is nevertheless the hub of botanical. enterprise in India and the Colonies. The whole key to the situation is simply this, that the Colonial office depends chiefly upon Kew for its scientific advice where Colonial establishments are concerned, while Kew, on its own initiative, provides the latter with the necessary plants or seeds for the development of new industries, acting thereby as a connecting link between them. The staffs of the Colonial establishments, more- 
over, are recruited, in the main, from men trained at Kew, so that, although Kew has no official control over these institutions, the bond of union is nevertheless a very intimate one. The functions of Kew in this connection have been so lucidly summarized by M. A. Milhe Poutingon, in a report presented to the French Government, that I cannot do better than reproduce them here:

(I) Kew brings together new species and varieties of economic plants, and selects those from among them that are best adapted for propagation in the Colonies. It is hence an intermediate house and a centre of supplies for Colonial establishments.

(2) Kew supplies, or is instrumental in procuring, botanists and gardeners for the official botanical institutions of the respective Colonies, and also for private ventures. It is therefore a training and recruiting centre in this connection.

(3) Kew advises and supplies information to the Colonies on all matters of botanical and horticultural interest. It is hence a central bureau of information for the Colonies.

(4) Kew, finally, by the example of its own organization, helps to mould that of the Colonial centres, thereby ensuring a continuity of purpose and unity of plan which would not otherwise be attainable. Kew, in a word, may be looked upon as the botanical headquarters of the whole Empire from the cultural point of view.

The Colonial botanical establishments referred to above are of three grades, viz.:

(I) Gardens moulded on the pattern of Kew and administered by a scientific director (e.g., Ceylon, Calcutta, Madras, Mauritius, etc.).

(2) Smaller gardens administered by a skilled superintendent. There are many of these in India, and others in Hong Kong, Demerara (British Guiana), etc.

(3) Up till I 886 these two types were the only ones represented. To these a third type was added in that year, on the recommendation of Kew. This type, known as a botanic station, is organized on a smaller scale than either of the two preceding ones, being under the charge of a trained gardener; it is essentially an experiment station, from which the colonists are able to procure suitable economic plants and the necessary information for their successful cultivation on a commercial scale. The botanic stations were first established in the West Indies, and subsequently in the West African possessions. In 1898 the botanic establishments of the West 
Indian Islands (Barbadoes, Leeward and Windward Islands) were piaced under a special department of agriculture in charge of Sir Daniel Morris, K.C.M.G., as commissioner.

In illustration of the role played by Kew in the introduction of economic plants into the Colonies, cinchona and coffee may be taken as examples.

The introduction of cinchona into India, as is well known, was due primarily to the efforts of Clements $R$. Markham and his associates, who were deputed by the Government to collect young cinchona plants and seeds in the Andes. These were forwarded to Kew, and "upon the Royal Gardens devolved the duties of receiving and transmitting the seeds and plants to India, of raising a large crop of seedlings, of nursing the young stock, . . . and of recommending competent gardeners to take charge of the living plants from their native forests to the hill country of India, and to have the care of the new plantations there. Further, with the sanction of the Indian and Colonial Governments, it was arranged that our West Indian Colonies and Ceylon should be supplied with a portion of the seeds" (Abstract from Sir William Hooker's report to Parliament for I 86I). The result is too well known to require further comment.

The work undertaken by Kew in connection with coffee covered a still wider range. In I 862 a coffee disease made its appearance in Ceylon. The Government instituted an inquiry, and a botanist from Kew (Marshall Ward) was dispatched to Ceylon to investigate the disease. His reports having shown that it was impossible to combat the disease, Kew undertook to introduce a variety of coffee from West Africa, known as Liberian coffee, which was of a more resistant nature, and from i 874 to I 876 large consignments of seeds and of seedlings raised at Kew ${ }^{1}$ were forwarded in Wardian cases to Ceylon, India, Singapore and the Seychelles. Investigations were concurrently instituted on the habits of the plants in their original habitat, and the results were published in an official report.

These two examples may be taken as fairly typical of the rest, which are recorded in the reports of the Director to Parliament, and, subsequently, from I 887 to I 899 , in the "Kew Bulletin."

Among the many drug-yielding plants and their products which

1 These operations are carried on in forcing-houses situated at the back of the Curator's office. (See Plate X.) They are not open to the public. 
have formed the subject of investigation at Kew, the following may be mentioned: Eucalyptus, ipecacuanha, the plant yielding euphorbium of commerce, tea, cocoa, opium, tobacco, india-rubber, Ferula Sumbul, balsam of copaiba, balsam of Peru, cardamoms, castor oil, chicle gum, arrowroot, Strychnos Ignatii, sugar-cane, dragon's blood, frankincense, aloes, cuprea bark, cola, star anise, jalap, vanilla, ginseng, cocoanut oil, derris, Paraguay jaborandi, myrrh, gum benjamin, coca, Antiaris toxicario and strophanthus. A bibliography, by Mr. B. D. Jackson, of the scientific work published in connection with Kew from I 844 to I 895 , is to be found in the "Kew Bulletin" for January, I 897 , and a supplement thereto in the July number of the same year; to this the reader interested in the subject is referred for details. A passing reference, however, must be made to two works indispensable to every working botanist, whatever his sphere of activity may be, viz., the "Genera Plantarum" and the "Index Kewensis," in the preparation of which the labors of the ex-Director, Sir J. D. Hooker, have played an important part. The most important publication in the eyes of the pharmacist is, however, the "Kew Bulletin," published under the ægis of the former Assistant Director, Sir Daniel Morris, and edited by the Director. Since 1899 the publication of the "Bulletin" has ceased, although appendices, consisting of lists of staffs, botanic establishments, new garden plants, and seeds for exchange, are still issued. All matters of economic interest dealt with at Kew during the period of I 887 to I 899 are recorded in the "Kew Bulletin," which was "a continuous record of Kew work in all its various aspects" during that period.

Every facility is offered to the research student, whether it be in the gardens, laboratory, or museums, but no provision, beyond that offered to the general public, is made for the elementary student, this function being now relegated to the Chelsea Physic Garden and to the Royal Botanic Society's Gardens in Regent's Park. Among the many authors of eminence whose works are largely based on the facilities provided at Kew, the following may be mentioned: Daniel Hanbury, who frequently visited Kew in connection with the "Pharmacographia," of which he was joint author; Triana, who consulted the collections at Kew for the preparation of his work on Cinchonas; J. E. Howard, the author of classic monographs on the genus Cinchona; Bentley and Trimen, whose well-known work on medicinal plants contains numerous plates of plants figured from the 
Royal Gardens ; Sir George Watt, the author of the "Dictionary of the Economic Products of India," who is at the present time working at Kew; and last, but not least, Mr. E. M. Holmes, the veteran pharmacognosist, one of the most indefatigable investigators of the riches of Kew.

Kew, finally, is under constant requisition by manufacturers, druggists, and drug-brokers, on questions of economic botany which affect their respective callings.

[There is no connected account of Kew at present available, most of the literature on the subject consisting of scattered collections of facts from which it is extremely difficult to construct a coherent record. To the student who is desirous of pursuing the subject further, the following list may be of use, as it includes the most important works on the subject:

Historical account of Kew to I84I, by the Director, in the "Kew Bulletin" for December, ISgr. Contains copious citations from the earlier literature.

The annual reports of the Director of Kew Gardens to Parliament from I850 to I882. Index to reports (I862-82) on page 3 of "K. B." for I890. Irregular reports of varying nature (in Parliamentary Blue Books) from IS44 to IS5o.

"Kew Bulletin" from I887 to I899.

Popular Guide to the Royal Botanic Gardens of Kew-Ist to 2Ist editions, by the Director of Kew (I847-IS62); 22d to 3oth (the last published) editions, by Prof. Daniel Oliver (I863-I885). This excellent little work has long been out of print, and copies of it are scarce.

John Smith : Records of the Royal Botanic Gardens, Kew, I8So. An account of the old "Botanic Gardens" during the official connection, as curator, of the author, between the years IS22 and I864. Controversial and scarce.

Report to the Lords Commissioners of His Majesty's Treasury of the Departmental Committee on Botanical Work and Collections at the British Museum and at Kew, I9oI. Contains a summary of previous enquiries, a bibliography, and an elaborate memorandum by the Director of Kew. Parl. Return. Commons, No. 205.

The various hand-lists of the living collections, published at Kew, also contain interesting summaries of the way in which the respective collections originated, but most of the information under this head will be found in greater detail in the "Kew Bulletin." A complete list of the hand-lists will be found in the Parliamentary Report previously cited.]

III.

THE ROYAL BOTANIC SOCIE'TY'S GARDENS, REGENT'S PARK.

Regent's Park was opened in I8I2, during the regency of the Prince of Wales, afterwards George IV, and named "Regent's Park" in his honor. The area now belted by a circular road known as the "Inner Circle," and consisting of over i 8 acres of ground, was not included in the plan for laying out and planting the park, as it was 

the intention of the Prince Regent to erect a royal palace on that site. The project, however, was never put into execution, and, in I 838 , we find that this plot of ground was occupied by a nursery garden, known as Jenkins' Nursery and Pleasure Ground. Towards the close of that year several influential people interested in botany approached Her late Majesty's commissioners with the object of obtaining a lease of Jenkins' Nursery from the Crown, for the purpose of converting it into a combined ornamental and botanic garden. Their quest was successful, and, in I 839, the Royal Botanic Society of London was permanently established, a Royal charter being granted to Bernard Edward, Duke of Norfolk; Charles, Duke of Richmond; William Charles, Earl of Albemarle; LieutenantColonel Robert Rusbrooke; Philip Barnes (the originator of the scheme); and James de Carle Sowerby, "for the promotion of botany in ail its branches, and its application to medicine, arts, and manufactures, and also for the formation of extensive botanical and ornamental gardens within the immediate vicinity of the metropolis."

The property, when taken over by the Society, consisted of "a nearly level plateau, only rising gently from the circumference to the centre." The contents, bought from the nurseryman for $£ 2,000$, consisted of the following: A belt of elm trees of considerable size on the outer margin; an inner circle of small beeches; a group of trees on a lawn, where the secretary's house and museum now stand, and a few other trees scattered about; two old greenhouses; a cottage of wood and brick; some sheds; and general nursery stock.

One of the first steps taken by the Fellows of the Society was directed towards the accomplishment of the main purpose of their charter, namely, the conversion of the plot of ground they had acquired into a botanical and ornamental garden. With this object in view a prize was offered by the Society for the best plan submitted dealing with the laying out of the ground along these lines. The difficulties that the numerous competitors had to contend with, in constructing a plan for a garden that would combine the requisite scientific features with those of an ornamental ground, were so great, that, although the prize was awarded for one of the plans sent in, the latter was not considered sufficiently satisfactory for adoption in its entirety. It is to R. Marnock, who was appointed Curator on the recommendation of $\mathrm{J}$. C. Loudon, the well-known horticulturist, that the Society is indebted for the very effective arrangement of its gar- 
dens, and it is indeed difficult to realize that their diversified landscape has been artificially evolved from a nearly flat piece of market garden.

The soil which Marnock had to deal with was the rather unin. viting London clay, a stiff clay sprinkled with coarse gravel, the latter becoming more abundant a little to the south of Regent's Park; this clay, however, by reason of its impermeability, was well adapted to the first operation that was undertaken, namely, the formation of the Lake (see Plates XVII and XVIII). The material removed for this purpose was utilized in constructing the mound which divides the Lake from the main walk (see Plate XVII for this and other details described below). The north of the gardens was next attacked and the terrace constructed. On the southern portion of this terrace the principal portion of the Conservatory was erected in I845, the wings being added later, the east wing in I870, the west wing in 1875 , by private subscription among the Fellows. This conservatory was the first iron and glass house of considerable size erected in England, while its heating arrangements were also a novel feature at the time. The hot-water pipes are placed underground instead of being above the surface, as is usually the case; this arrangement presents a neat appearance, but it is rather wasteful. The east wing of the Conservatory is partitioned off as a tropical house, the main body of the building being heated to an intermediate temperature (between $50^{\circ}$ and $60^{\circ} \mathrm{F}$. in winter). The northern portion of the terrace, situated at the back of the Conservatory, was converted into an exhibition ground, new features being introduced into the arrangement of this also, in that sloping grass banks were substituted for the conventional tables under tents, and the whole was covered over with one spread of canvas. This system, however, has now been abandoned, and the customary method reverted to.

An arboretum was included in the original laying out of the gardens, but, owing to the limited space available, it has been reduced; there are, nevertheless, many handsome and interesting trees, including some fine willows. On the west, a Spring Garden, an American Garden, a Rose Garden, an Italian Garden, and an agricultural department were formed. These have been suppressed with the exception of the American Garden, which has preserved its initial arrangement, albeit it is now devoted to a show of rhodo- 



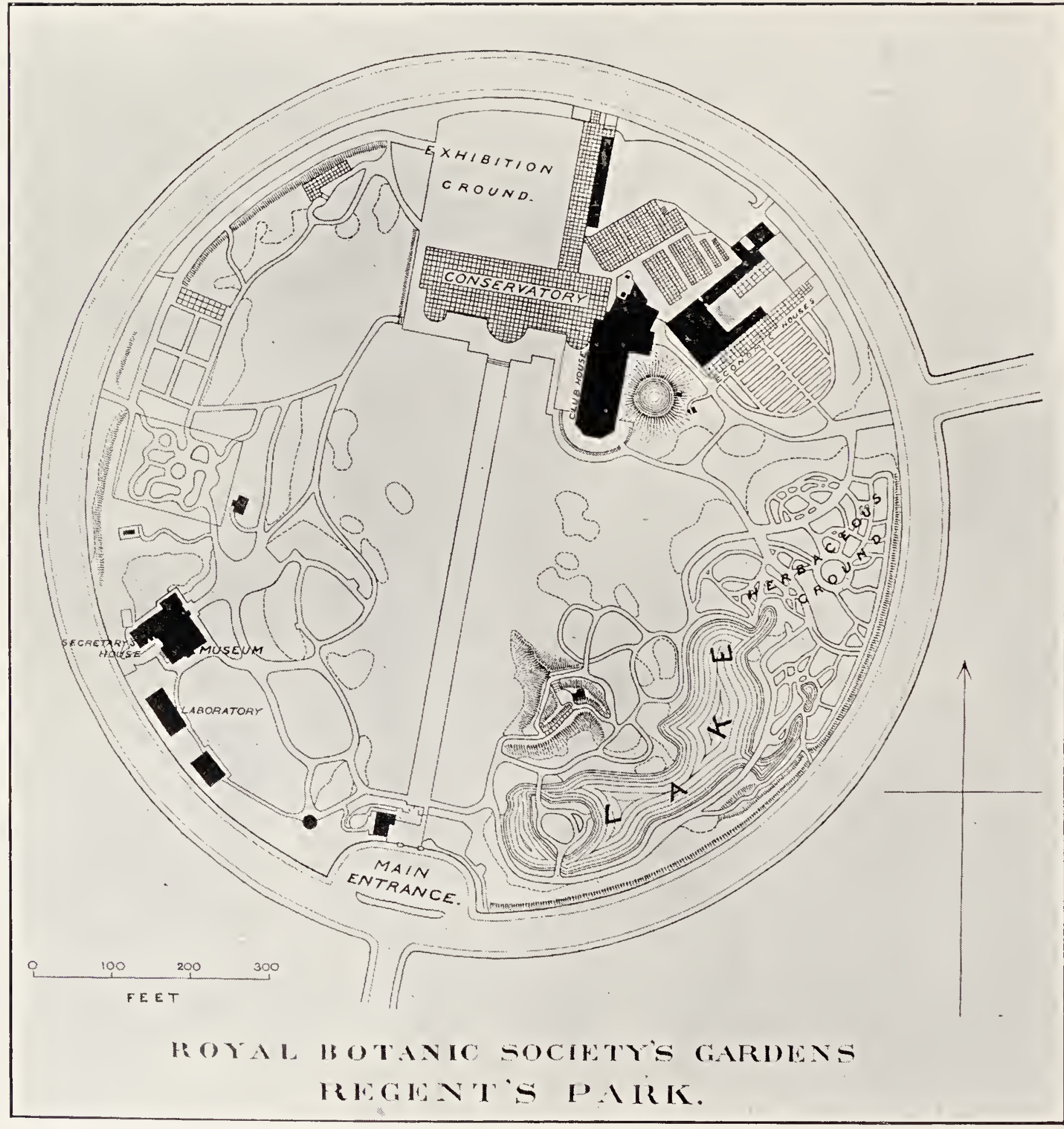

Plan OF the ROYAl BOtanic SOCIETY'S GaRdens.

NOTE. - The plant houses are indicated by crossed lines, and the other buildings by black areas. 

dendrons, exhibited during the spring and summer months. Immediately to the north of this a horticultural ground has been laid out for the use of the students of the recently established horticultural school of the Society.

The portion of the gardens which possesses most interest for us is situated on the northeast, where the Economic Department is located, and on the east, near the upper end of the lake, where the Herbaceous Ground is to be found. The economic section proper, which has always received special attention at the hands of the Society, consists of a collection of trees and shrubs, and of a range of three lean-to houses maintained at three different temperatures, the central one, or stove, being heated to $65^{\circ}-70^{\circ} \mathrm{F}$., and the end ones to $60^{\circ}-65^{\circ} \mathrm{F}$. and $45^{\circ}-50^{\circ} \mathrm{F}$. respectively. The economic garden formeriy comprised a central portion for the reception of hardy herbaceous plants, and an outer portion surrounding it, in which economic trees and shrubs were grown, but the contents of the former have now been merged into the general herbaceous collection. In the Herbaceous Ground, which is especially rich in medicinal plants, the original arrangement of the plants has been adhered to, and is of special interest because it also originated with Marnock. Obvious as its advantages are, it only appears to have been adopted in one other garden in the kingdom, this being at the Cambridge Botanic Garden, where the energetic curator, Mr. R. Irwin Lynch, has made use of it to the greatest advantage. The beds are of different shapes and sizes, and are so laid out that each bed accommodates the plants belonging to one natural order. By this means the relative magnitudes of the various orders are shown at a glance. Closely related natural orders, furthermore, are grouped together, so that their relationships, as well as their respective importance in numbers, are indicated. In the centre of the Herbaceous Ground there is an enclosure containing a set of meteorological instruments, including a series of earth thermometers from a depth of 3 inches to one of 16 feet below the surface of the ground. Records of these readings are made three times a day, and the most important of these are printed in the society's "Quarterly Record."

The following is a list of the more interesting medicinal plants grown out of doors; some of them are to be found in the section especially devoted to economic plants, but the largest number is in the Herbaceous Ground: 
Abies balsamea, Mill.; Achillea Millefolium, L. ; Aconitum Napellus, L.; Aconus Calamus, L., or Sweet Flag; Alkanna tinctoria, Tausch., from which Alkanet root is obtained; Althoea officinalis, L., the Marshmallow; Anthemis nobilis, L.; Artemisia Absinthium, L.; Arundo Donax, L., the "Canne de Provence" of the French Codex; Atropa Belladonna, L.; Carthamus tinc. torius, L. ; Chrysanthemum Parthenium, Bernh.: Colchicum autumnale, L..; Crocus sations, L.; Cytisus Scoparius, Link. ; Daphne Laureola, L., and D. Mezereum, I., two of the three species of Daphne yielding the Mezereon Bark of the British Pharmacopœia; Datura Stramonium, L.; Delphinium Staphisagria, L.; Digitalis purpurea, L.; Ecballium Elaterium, A. Rich., the Squirting Cucumber, from which Elaterin is prepared; Eupatorium perfoliatum, L.; Ferula Narthex, Boiss., and other species of Ferula yieiding gumresins ; Ferula Sumbul, Hook. f. ; Foniculum capillaceum, Gilit. ; Fraxinus Ornus, L., the Manna Ash; Gentiana lutea, L., from which the official Gentian Root is obtained; Glycyrrhiza glabra, L., or Liquorice ; Inula Helenium, L.; Iris Florentina, L., and other species yielding fragrant rhizomes; Juniperus Sabina, L.; Laurus nobilis, L.; Linum usitatissimum, L.; Mandragora officinarum, L. ; Melissa officinalis, L., or Balm ; Melilotus officinalis, Lam., or Melilot; Mentha piperita, L., the Peppermint, and M. Pulegium, L., or Pennyroyal; Menyanthes trifoliata, L, or Bog bean; Nicotiana Tabacum, L.; Papaver somniferum, L.; Peucedanum graveolens, Benth.; Phytolacca decandra, L., the source of Poke root; Polygonum Bistorta, L., or Bistort; Polypodium vulgare, L., whose rhizome is official in the French Codex; Pulmonaria officinalis, L., or Lungwort, whose leaves, still retained in the Codex, are a relic of the old doctrine of signatures; Quercus pedunculata, Ehrh., and Q. Suber, L.; Rhammus catharticus, L.; Rheum officinale, Baill., and R. palmatum, L., var. tanguticum, sources of Chinese Rhubarb; Rosmarinus officinalis, L., or Rosemary; Ruta graveolens, L., or Rue ; Rubia tinctorum, L., Madder ; Sambucus nigra, L.; Sanguinaria Canadensis, L.; Solanum Dulcamara, L. ; Tanacetum vulgare, L.; Taraxacum officinale, Weber; Trigonella Fcnum-gracum, L., or Fenugreek; Tussilago Larfara, L.; Valeriana officinalis, L. ; Veratrum viride, Soland.; and Verbascum Thapsus, L., or Mullein.

The range of Economic Houses was first erected in 1873 , under the secretaryship of Mr. W. Sowerby. It was entirely rebuilt last year (I904), and although several plants were lost owing to the severe weather that occurred while the work was being proceeded with these are being rapidly replaced. The following is a list of some of the more interesting plants, from the pharmacist's point of view, growing in these houses at the present time; they are being added to every day, and the collection, which is already the most complete one of living exotic economic plants in London, will be, before long, a thoroughly representative one :-

Aloe vera, L., and other species of Aloe ; Areca Catechu, L.; Balsamodendron Myrrha, Nees; Bixa Orellana, L.; Casalpinia Sappan, L., whose heart-wood is official in the Colonial and Indian Addendum of the British Pharmacopœia, 



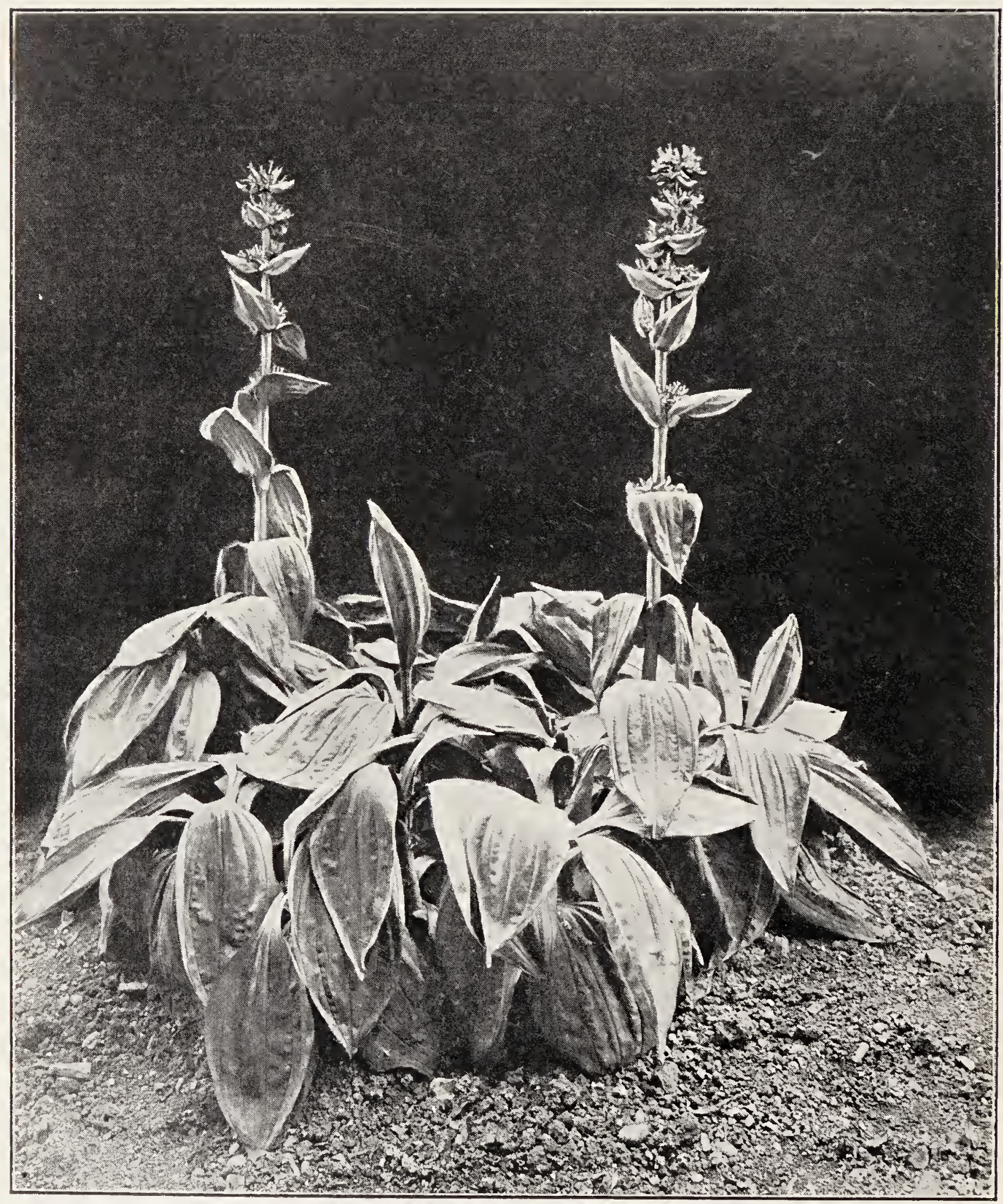

GENTIANA LUTEA, L.

Growing in the Royal Botanic Society's Gardens. 


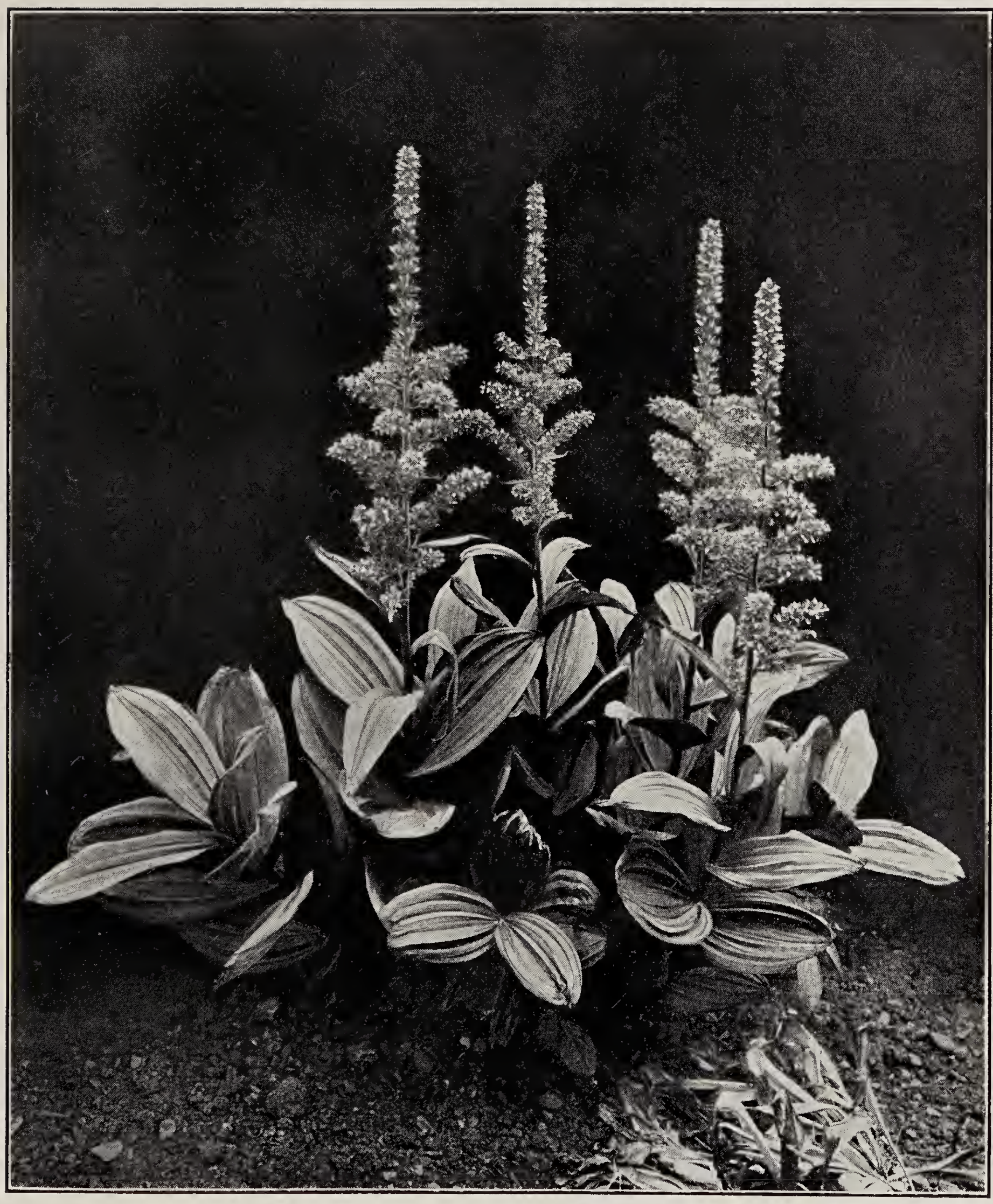

VERATRUM VIRIDE, SOLAND.

Growing in the Royal Botanic Society's Gardens. 

under the name of "Sappan ;" Canella alba, Murr.; Castilloa elastica, Cerv., source of Central American rubber; Chondodendron tomentosum, R. \& P., the source of true Pareira Brava; Cinchona officinalis, L., and other Cinchonas yielding medicinal barks ; Cinnamonum Camphora, Nees ; Convolvulus Scammonia, L., source of Scammony root, Scammony, and Scammony resin; Croton Eluteria, Benn., from which Cascarilla bark is obtained, and C. Tiglium, L.; Curcuma longa, L.; Dipteryx odorata, Willd., the plant which yields 'Tonka beans; Drymis Winteri, Forst., the source of true Winter's bark ; Eucalyptus globulus, Labill., and other species of Eucalyptus; Euphorbia resinifera, Berg; Ficus elastica, Roxb., from which East Indian rubber is obtained; Gossypium herbaceum, I., and other species of Gossypium; Gynocardia odorata, R. Br., formerly supposed to be the source of Chaulmoogra seeds and oil; Hevea Braziliensis, Muell., from which Para rubber is obtained; Illicium verum, Hook. f.; Landolphia gummifera, Lam., the source of Madagascar rubber; Musa sapientum, L., and var. Paradisiaca; Nicotiana Tabacum, L.; Nopalea coccinellifera, Salm-Dyck; Opoponax Chironium, Koch.; Peumus Boldus, Molina; Piper angustifolium, L., P. Betle, L., P. Cubeba, L., and $P$. longum, L.; Pogostemon Patchouli, Pellet., the essential oil of which is used in perfumery; Ricinus communis, L.; Santalum album, L.; Smilax officinalis, Kunth, the reputed source of Caracas Sarsaparilla ; Strychnos Nux.vomica, L.; Styrax Benzoin, Dry.; Terminalia sp., yielding Myrabolans; and Urginea maritima, Baker.

The conservatory is chiefly used for the display of ornamental plants, but it also includes a few that are of medicinal interest, such as various species of Aloe; Cereus grandiflorus, Mill.; Illicium verum, Hook. f.; Peumus Boldus, Molina; several of the rubber-yielding plants; various Eucalypti; Nopalea coccinellifera, Salm-Dyck; Musa sapientum, L., and varieties, etc. In connection with the last-named genus, it is of interest to note that it was from a plant grown in this conservatory that the late Queen Victoria tasted the banana for the first time. At the rear of the conservatory, to the east, there is a glass corridor flanking the exhibition ground on the east, and leading out to the gate at the north end of the gardens; this is used for educational and other exhibitions from time to time. It is ornamented with creepers up the sides and roof, and with a row of camellias on each side, which can be removed while exhibitions are being held—otherwise it is unoccupied.

In addition to the economic houses and conservatory, and situated between them, there are houses for the accommodation of filmy ferns, succulents, ferns, orchids, etc., and a large Victoria Regia House, opening into the corridor of the conservatory. These, with the exception of the succulent house, contain no plants of medicinal interest, and there is nothing in the last-named which is 
not equally well represented in the Economic Houses. Other adjuncts of this section of the gardens are propagating houses and frames, a plant hospital, potting sheds, etc.

The secretary's house, and the adjoining museum, which is also used as a council-room and as a fellows' meeting-room, was erected in $\mathrm{I} 85 \mathrm{I}$ to take the place of the cottage of wood and brick mentioned above. The specimens in the museum were at first entirely educational in character; these have been retained and added to, and comprise an interesting series, illustrating the natural history of plants. In the course of time, however, this special collection has developed into a general botanic and economic one; it comprises a goodly collection of drugs, including a series of the different varieties of aloes, tea and india-rubber, and a sample from the first consignment of gutta-percha brought into this country; the collection of gums and gum-resins is an extensive one, as is also that of vegetable oils and fats. Of secondary interest to us are the collections of tropical fruits and vegetables, of woods and dyes, and those of tanning materials, fibres and fibre-plants and cereals. In addition to the specimens themselves, there is, in the museum, a valuable collection of oil paintings of plants and flowers by the Hon. Evelyn Ellis.

The Laboratory was built in I902, in connection with the Gardening School. It is fitted up with benches, gas and water being laid on, and is also adapted for use as a lecture hali.

\section{THE WORKING OF THE GARDENS.}

The management of the Society's affairs, including the Gardens, is in the hands of a Council elected by vote of the Fellows. A president is also elected yearly, but, up to the present, every president has been re-elected until his death. The first president was Charles, Duke of Richmond ( to I 842 ); the second, Bernard Edward, Duke of Norfolk ( to I 856); the third, the late Prince Consort (to I 862); the fourth, Lord de La Warr ( to I 869 ); the fifth, the Duke of Teck (to I898); and the sixth, his son, the present Duke of Teck, who still occupies the position. The Society has, moreover, always enjoyed distinguished patronage; the late Queen Victoria was its patron from the beginning, until her death, and the Duchess of Kent and the Duke and Duchess of Cambridge the first vice-patrons. King Edward is the present patron and Queen Alexandra, patroness, 


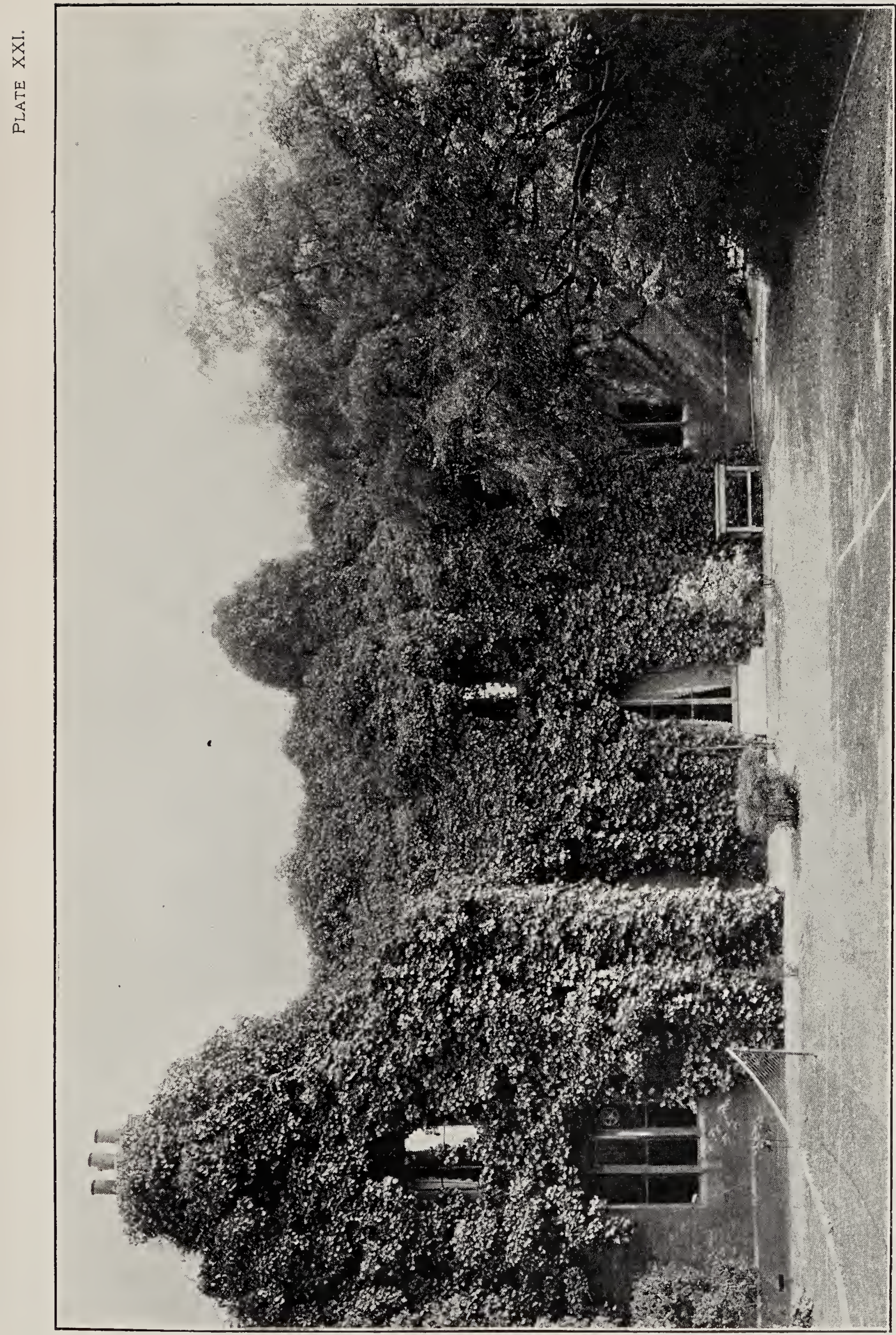

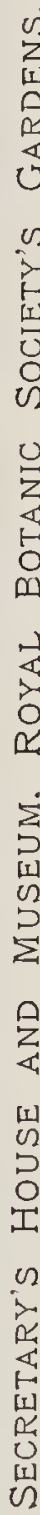



while the Prince and Princess of Wales are vice-patron and vice. patroness respectively.

The principal officer of the Society is the Secretary. J. de Carle Sowerby, one of the founders, was the first to hold office in this capacity, and this post has since been occupied by members of the same fainily, the present Secretary being Mr. J. Bryant Sowerby, F.L.S.

The gardening staff is in charge of Mr. E. F. Hawes, who is likewise Chief Instructor of the Practical Gardening School. There is also a Curator attached to the Museum.

The Society, depending entirely as it does upon the Fellows' subscriptions for its funds, has found it necessary to effect a compromise in the organization of its functions, especially in view of the fact that the renewal of the lease of the Gardens from the Crown, in I90 I, was only secured by paying a higher price than before. The inducement required to attract a larger number of Fellows has been provided by the introduction of a number of features for their comfort and amusement, such as a croquet and tennis ground, suitable accommodations for garden fêtes, frequent displays of flowers and decorative plants, and a club house.

It is, however, in its educational capacity that the Society claims our attention, for in so far as medical and pharmaceutical students are concerned, it undoubtedly fulfils the chief rôle in London in supplying the necessary materials for the study of living plants. Close upon seven hundred students' tickets are issued annually through the medium of the professors and teachers in the respective schools, these tickets being available daily, until 3 o'clock in the afternoon; after that hour the Gardens are reserved for the use of the Fellows and visitors. In addition to this, from 50,000 to 60,000 cut specimens are distributed among such students every year. Lectures in Botany were formerly delivered on certain mornings in the Gardens to the students of the Pharmaceutical Society's School, but they have been discontinued for some years.

Among the educational features of the Society the lectures delivered from time to time on botanical subjects must be included; these, together with the other proceedings of the Society, are published in its "Quarterly Record."

In 1897 the educational side was further developed by the institu. tion of a Practical Gardening School. The training consists of a 
course, extending over a period of three years, which is essentially practical in character, although it is accompanied by a series of lectures delivered in the Laboratory. The students consist, in part, of pupils who have obtained scholarships from the London School Board-now the Education Department of the London County Council. These, originally ten in number, acquitted themselves so satisfactorily that the number has since been increased to twenty. In addition to the scholars, there are several independent students, many of whom are ladies.

This account would not be complete without a concluding reference to the educational exhibitions that are occasionally held in the Gardens. These are illustrative of work done in schools on the toolong neglected subject of Nature Study, and must appeal to everyone who has the cause of education at heart.

[Further details concerning the Royal Botanic Society's Gardens will be found in the Society's "Quarterly Record," first published in ISSo, and continued from that date to the present time. In vol. III of that publication (No. 36, p. 216. London, I888) there is a short historical account of the Society contributed by Mr. W. Sowerby, the Society's secretary at that time, on the occasion of the fiftieth anniversary of the Society. There is also an official Guide to the Gardens (London, I900) which contains a number of interesting photographs of their characteristic features, in addition to an excellent popular account of the Gardens by Mrs. J. B. Sowerby. More recent developments still are briefly summarized in an illustrated booklet issued by the Council, and entitled "The Royal Botanic Society of London." ]

\section{IV.}

THE CHELSEA PHYSIC GARDEN.

Before commencing an account of the Chelsea Physic Garden, it will be necessary to give a brief résumé of the origin and development of the society by which the garden was founded. The Society of Apothecaries of London-in Latin, "Societas Pharmacopciomm Londinensis," or "Societas Pharmaceutica Londinensis" - was incorporated by Royal Charter in 1606 , and was then united with the Grocers' Company, an ancient City guild. The existence of the Society as an independent body dates from 1617 , when a new charter was obtained from James I, and the Society severed its connection with the Grocers' Company.

The Society of Apothecaries, or "Societas Pharmaceutica Londinensis," must not be confounded with the Pharmaceutical Society of 


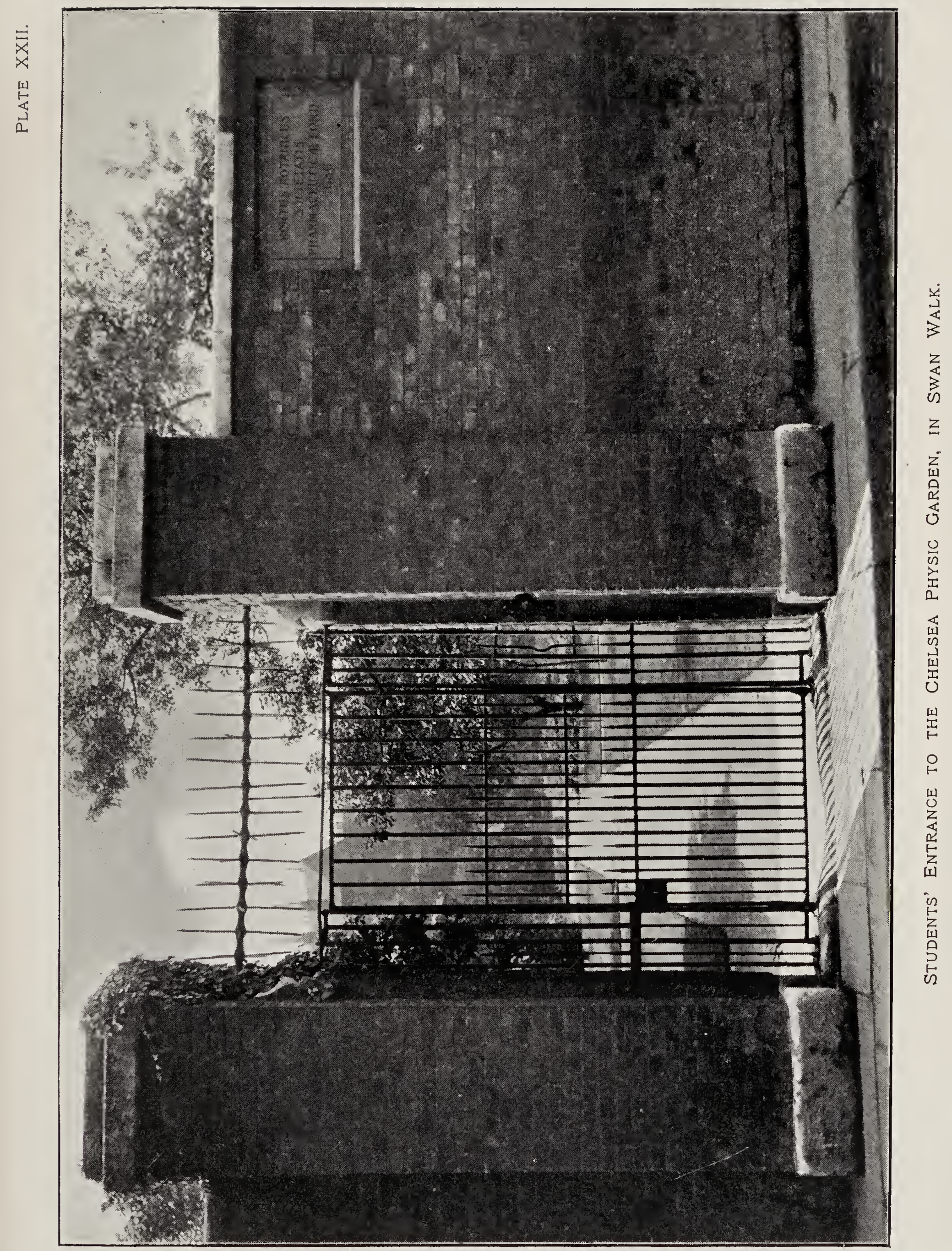



Great Britain, the latter having been established in I 84I, incorporated by Royal Charter in I 843 , and made, by the Pharmacy Acts of I 852 and I 868 , the only legal body in the United Kingdom for the examination and registration of pharmacists. It may seem strange to the American reader that the title of "apothecary" should not be synonymous with that of "pharmacist," and in order to explain this apparent anomaly, we must go back to an early date in the history of the Society of Apothecaries. "The "apothecary," at the time of the Society's inception, and for a considerable period thereafter, was nothing more nor less than a compounder of drugs, or dispenser, and the term is still used in this sense in the United States. By the end of the seventeenth century, however, the practice of prescribing drugs as well as that of dispensing them had been assumed by the apothecary, and by a decision of the House of Lords, in I703, it was definitely settled that the directing and ordering of remedies was, no less than their preparation, a legimate part of the apothecaries' functions. The powers of the Society of Apothecaries were further extended by the Acts of I748 and I8I5, which restricted the practice of the apothecary's art to such as were duly licensed by the Society. These restrictions only applied to London and its environs at first, but, by the latter Act, were made to comprise the whole of England and Wales. By these two Acts the Society was also empowered to appoint a board of examiners, and it is a significant fact that our existing medical schools are, in a great measure, the outcome of the evidence of training required from candidates by this board. The Society has, indeed, been a pioneer in the cause of education on more than one occasion, and, in I850, it imposed a preliminary examination in arts on its prospective licentiates. This examination may be looked upon as the forerunner of the preliminary knowledge in arts that is now essential for registration as a medical student in the British Isles. By the Medical Acts of I 858 and I 886, the licentiateship of the Society of Apothecaries was recognized as a complete legal qualification for the prac. tice of medicine, surgery and midwifery throughout the United Kingdom and Ireland. In the early days of the Society's existence the knowledge of the "art and mystery" of the apothecary was acquired through apprenticeship, and it is on record that the Society examined its apprentices as early as 1619; by the Act of I8I5 a five years' apprenticeship to an apothecary was made obligatory on 
every candidate for the license, but this restriction was removed by the Apothecaries' Act Amendment Act of 1874, and apprenticeship is now no longer necessary.

In addition to the licentiateship, the Society of Apothecaries grants a dispenser's certificate, but this is of limited value, as it practically restricts its possessor to the work of dispensing for medical men; the Pharmacy Acts cited above making it unlawful for any person not registered under those Acts "to sell or keep open shop for retailing, dispensing or compounding poisons," or to assume the name of "pharmacist," "chemist" or "druggist." The " apothecary" himself, however, that is to say, the licentiate of the Society of Apothecaries, is free to practise pharmacy if he be so disposed, as the penalties imposed on persons who are not registered under the Pharmacy Acts do not apply to medical practitioners. ${ }^{1}$ The Society of Apothecaries, as a matter of fact, conducts an open pharmacy of its own at its hall in the vicinity of St. Paul's Cathedral. In connection with this section of the Society's work, it is of interest to note that a laboratory for the preparation of drugs was erected in $167 \mathrm{I}$, and that a "selling place" existed in 1672 , as shown by the Society's records. Drugs were only sold to apothecaries at first, but as time went on the Society developed an extensive business with the East India Company and other bodies, and, finally, the retail department was opened in $1822 .{ }^{2}$

We will now proceed to consider in greater detail the activities of the Society in promoting the study of botany, as exemplified more especially by the establishment of the Physic Garden at Chelsea and by the maintenance of the latter during two and a quarter centuries.

It is on record that the members of the Society of Apothecaries interested themselves in botanical pursuits soon after their incor-

${ }^{1}$ To this brief explanation of the status of the licentiate of the Society of Apothecaries, it is necessary to add a few particulars in order to give an exact presentation of the facts. The diploma of "Licentiate of the Society of Apothecaries " does not of itself authorize its possessor to act as a medical practitioner, but it entitles him, in common with the holders of other degrees and qualifications in medicine and surgery, to have his name placed on the British Medical Register, on payment of the requisite fees. The person so registered becomes, ipso facto, a legally recognized medical practitioner, to whom the above-mentioned provisions of the Pharmacy Acts do not apply.

${ }^{2}$ Those interested in the history of the Society may consult Mr. Barrett's "History of the Society of A pothecaries of London" for further particulars. 
poration, and that they made periodical excursions in search of plants early in the seventeenth century. We are indebted to Thomas Johnson, editor of Gerarde's Herbal, and one of the Society's members, for several accounts of these early "Herbarizings" as they came to be called. By I633 an annual General Herborizing was definitely instituted, ${ }^{1}$ while other less formal ones were also undertaken from time to time.

The annual excursions were confined to the members of the Society and their friends, and those who participated in them were known as "Socii Itinerantes." From Johnson's account of these excursions we learn that the itinerant members used to travel considerable distances, sometimes going as far afield as Anglesea or Bath. The number of members taking part in the excursions appears to have dwindled as time went on, and the task of collecting plants for the General Herborizing came to be associated with the duty of the Society's Demonstrator of Plants. This is made apparent by the following abstract from the instructions issued in 1773 by the Garden Committee, in connection with the office of Demonstrator of Plants:-_ He [i.e., the Demonstrator of Plants] is expected to make some annual excursion, for two days at least, preparatory to the Society's General Herborizing, inviting two or three of the ablest botanical members to his assistance. The intention being to collect such vegetables as are not commonly found in the environs of the metropolis, to be demonstrated by him at the meeting appointed for that purpose . . . ." The plants thus collected were exhibited to the members on a day specially appointed for the purpose in July. The office-bearers of the Royal Colleges of Physicians and Surgeons were invited to these exhibitions, which were held, until 1836 , at some inn in the suburbs. At this function the Demonstrator gave to the assembled guests a description of the specimens collected and the demonstration was followed by a dinner where "haunches of venison formed conspicuous elements of the entertainment." With the advent of Lindley as Professor of Botany and Prefectus Horti, in 1836 , the practice was inaugurated of holding the annual exhibition of plants and General Herborizing

${ }^{1}$ According to Pulteney ("Historical and Biographical Sketches of the Progress of Botany in England," London, I790) these annual Herborizings were subsequently discontinued for many years, but were systematically renewed after the foundation of the garden. 
at the Society's hall instead of at an inn. When the office of Professor of Botany and Prefectus Horti was abolished in 1853 the annual exhibition inevitably disappeared with it, ${ }^{1}$ although the dinner was continued.

The other herborizings to which allusion has been made were designed to meet the needs of the Society's apprentices. Five of these in each year were ultimately established, viz., two in May, one in June, one in July, and one in August, but there are no means of determining the exact period at which a definite series of these students' herborizings was instituted. It is apparent, however, that the organization of these excursions cannot have been far removed from the creation of the office of Demonstrator of Plants, and the duties of that functionary at these herborizings were defined in the previously mentioned instructions of 1773 as follows :- " He is to accompany and conduct the students of this Society in their search after indigenous plants, upon every day appointed for their private Herborizings, which are only five in each summer; when he is desired to use his best endeavours to preserve strict decorum among his pupils, and for directing and confining their attention solely to the intended busi. ness of the day." The details of the excursions are of the greatest interest, but we must needs content ourselves with a brief description of their salient features. These excursions invariably took place in the neighborhood of London, and were of one day's duration. The students met the demonstrator early in the morning at some place previously decided upon, and the members of the party, provided with their collecting boxes, set out on their journey through the suburbs, collecting plants on the way, and halting for breakfast at some inn. The business of the day then began in earnest, and the students, accompanied by the demonstrator, collected specimens and made observations. The route was varied on different occasions, the party sometimes returning to the breakfasting place, at other times proceeding further afield, but whatever the route might be, dinner at an inn was always provided at the end of the journey. At the conclusion of the meal the demonstrator described the peculiarities of the specimens which he had collected, before the student

${ }^{1}$ It is reasonable to assume that these botanical demonstrations were kept up during the whole period of Lindley's tenure of office, as there is no record of his rôle having been modified in this direction. I have, however, been unable to find any overt indication of the fact. 
audience, laying special stress on the therapeutical properties of such plants as were used in medicine. Tea then followed and the gathering dispersed for home, the students usually accomplishing the return journey on foot. These students' herborizings appear to have been continued uninterruptedly until i 834 , but they were abolished in the following year, owing chiefly to the ever-increasing extension of the metropolitan area and consequent inaccessibility of suitable localities for field work in botany.

Coming now to the garden itself, we find ourselves confronted with a mass of detail which renders a subdivision of the subjectmatter desirable in order to give some continuity to the account. The administrative and material details may conveniently be considered first, and we shall accordingly begin with these; a résumé of the botanical work accomplished in connection with the garden will then be given; and the whole account will be concluded by a general description of the garden under the present administration.

The ground now occupied by the Chelsea Physic Garden was originally leased from Charles Cheyne by the Society of Apothecaries in 1673 for a term of sixty-one years. The immediate object which the Society's members had in view in taking this lease was the acquisition of a suitable spot near the river for the erection of a barge-house, as it was customary for the City companies at that time to possess a state barge for participation in the Lord Mayor's show and similar functions. The plot of ground thus acquired was nearly four acres in extent, so that a part of it was utilized by the proprietors of the Laboratory Stock for growing medicinal herbs, and plants were transferred to it from the Society's garden at Westminster. ${ }^{1}$ A wall was built around the Chelsea Garden in I674 at the expense of fourteen of the Society's members, on the understanding that the Court of Assistants would contribute $£ 2$ every year forever to each of the six herborizings. A sum of $£ 50$ was also contributed towards the cost of this wall by the proprietors of the Laboratory Stock in return for the privilege given to them of growing herbs for their own use in the garden. A gardener must have been employed very

${ }^{1}$ Little is known of this garden, but it is evident, from an entry in Evelyn's Diary, that a Physic Garden was in existence at Westminster in the middle of the seventeenth century. It is also evident that the Society subsequently became connected with it in some way, for an arrangement was made in 1676 for removing the plants from thence to the Chelsea Garden. 
soon after the garden was established, for it is recorded that a man named Piggott, who had served in that capacity, was dismissed in 1677. Richard Pratt was chosen in his stead, and a lodging was provided for him in addition to his salary. In 1679 the first committee of management, consisting of the extraordinary number of seventy-one persons, was appointed, and, in I680, John Watts, a member of the Society, and one of the fourteen contributors to the cost of the wall, was elected gardener, with " the allowance of one or two Labourers" besides his salary. A "stove" was erected in the following year in the lower part of the garden, near the river, and, in 1683 , four young cedars of Lebanon, the first grown in this country, were planted. (For the positions which they occupied see " 9 " on Plate XXV). Two of the trees died after about a century's existence, and were cut down (I77I); of the remaining two (see Plate XXIII), one died in 1875 , and the other was removed in $1904 .{ }^{1}$ By 1685 the expenses of the garden began to assume such considerable proportions that a plan was adopted in that year by which the entire management of the garden was handed over to Watts for seven years, on the condition that the garden and the buildings therein were to be kept in good order and that a catalogue of all the plants was to be prepared. He was allowed an annual sum for these services, in addition to all expenses incurred in cultivating the ground used by the proprietors of the Laboratory Stock. Each member of the Society was allowed a key of the garden at his own expense.

It was during the first year of Watts's lease that Evelyn visited the garden, and it will not be without interest to reproduce his entry, as it gives us some insight into the condition of the garden at that date ( I685):-

" 7 Aug. I went to see Mr. Wats, keeper of the Apothecaries Garden of Simples at Chelsea, where there is a collection of innumerable rarities of that sort particularly, besides many annuals, the tree bearing jesuits bark, which had don such wonders in quartan agues. What was very ingenious was the subterranean heate, conveyed by a stove under the conservatory, which was all vaulted

' A limb was blown off in I 8 I 2 from one of these cedars, and from it a chair was made. In 1846 another $1 \mathrm{imb}$ was broken off in the same way, but whether from the same tree or not, is not stated, and from this four chairs were made. 


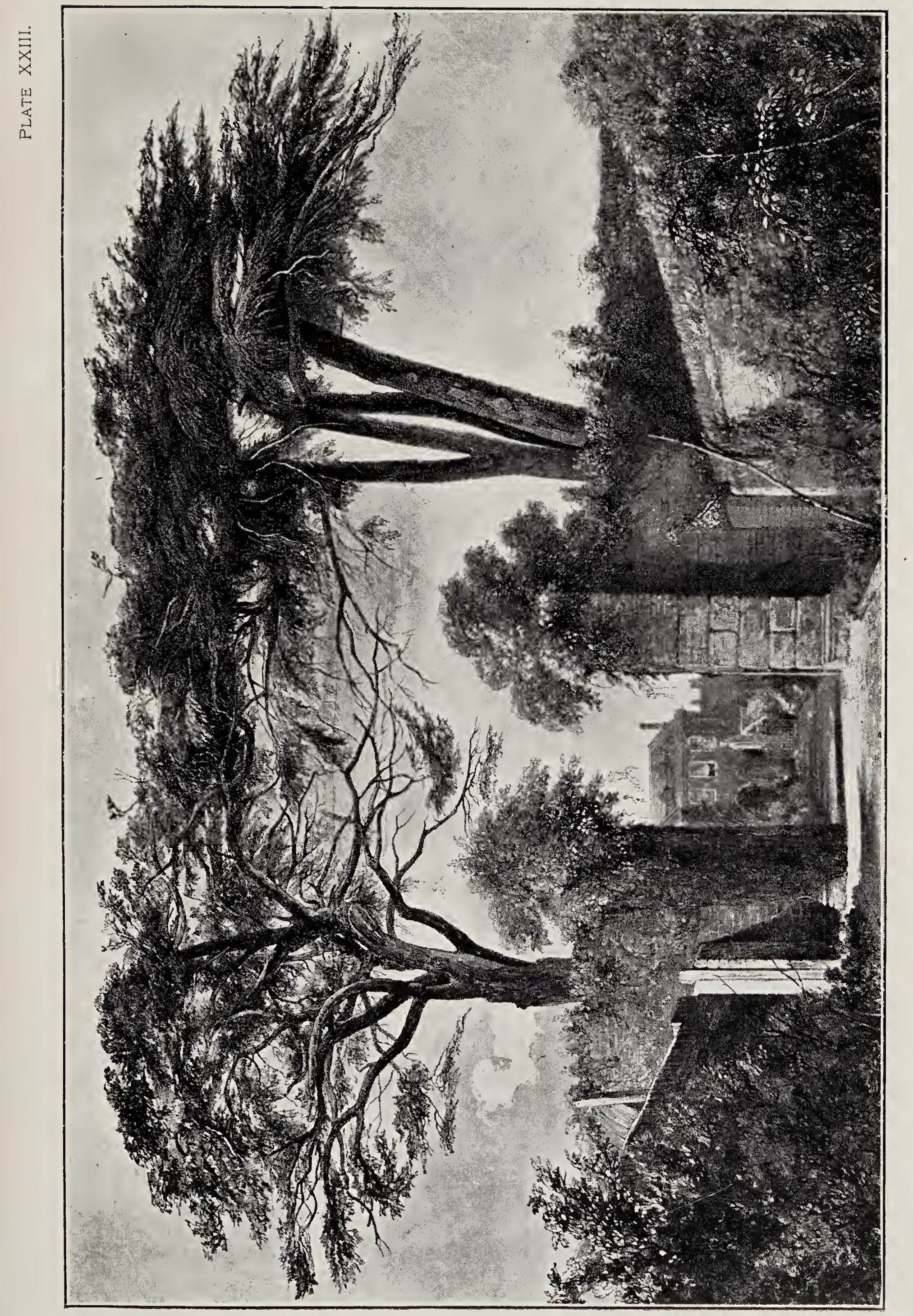

足 

with brick, so as he has the doores and windowes open in the hardest frosts, secluding only the snow." 1

After the expiration of Watts's lease in I693, Samuel Doody, F.R.S., also a member of the Society, took over the charge and management of the garden on terms similar to those previously made with Watts. This arrangement, however, soon proved unsatisfactory and Doody was absolved from his obligations in I695; but it is nevertheless probable that he continued to manage the affairs of the garden until his death in I706. After Doody's decease the relinquishment of the garden was seriously contemplated, but a committee, which was specially appointed to decide the question, resolved upon its retention; and an arrangement was made in I708 by which the garden was leased to such members of the Society as chose to subscribe a sum of $£$ roo per annum among themselves towards the upkeep of the garden. This utterly unworkable scheme had to be abandoned before long, and, in I7I3, definite fees were imposed on the Society's constituents. In I 7 I 4 it was decided that, for the time being, the garden should be maintained by the Corporation. $^{2}$ From this date until 1722 the affairs of the garden were in a somewhat unsettled condition, and the gardener or gardeners employed were evidently unimportant officials, as there is no gardener mentioned by name in the Society's records during that period. The decrease in importance of the post of gardener was accompanied by a correspondingly increased importance in that of Demonstrator of Plants. We have already seen that John Petiver, F.R.S., officiated in the latter capacity in 1709 , and although it is more than probable that he had occupied the post for some time previously, the circumstances connected with the garden at this time were undoubtedly such as to bring him in close contact with its affairs, and to pave the way for the step which was taken in 1724 of entrusting the direction of the garden to his successors in office.

1 Textually rendered from Bray's edition of the Diary. The abstract previously given in the introductory chapter was taken from the emended version in Fieid's work (see p. 4).

2 The term "the Corporation" has been used, throughout this chapter, to denote the Society of Apothecaries of London, in its capacity as a corporate body. This explanation is rendered necessary by the fact that the Corporation of the City of London is generally known as "The Corporation." 
In I7I 2 Dr. Hans Sloane ${ }^{1}$ purchased the manor of Chelsea from William, Lord Cheyne, and, as the Society's garden formed part of this estate, a deputation from the Society waited upon its new owner in I7I4 to confer with him respecting the affairs of the garden. The immediate result of this conference is not known, but it can be safely surmised that the events which we are about to describe were the ultimate outcome of the interview. A second conference with Sir Hans Sloane took place in I 7 8 , in which the affairs of the garden were again discussed, and within a few weeks after the event Sir Hans Sloane intimated that he was prepared to transfer the property to the Society on certain conditions. In conformity with his promise he conveyed the garden to the Apothecaries' Society by deed in I722. It was stated in this deed that the conveyance was made " to the end that the said garden might at all times thereafter be continued as a physick garden, and for the better encour-

${ }^{1}$ Hans Sloane was born in Ireland in 1660 , of Scotch parents. He went to London about his nineteenth year to study medicine, and while there he came into contact with Ray the naturalist. This association was instrumental in developing his taste for botanical subjects, and during his subsequent stay in Paris in 1683 he attended lectures on botany by Tournefort, as well as on anatony by Duverney. After leaving Paris Sloane went to Montpelier where he became acquainted with the celebrities of its University and commenced his collection of plants. After travelling in Languedoc to increase his collection, he returned to London in r684. He was elected a Fellow of the Royal Society in I685, and a Fellow of the Royal College of Physicians in 1687 . In the latter year he accompanied the Duke of Albermarle to Jamaica, where he further enriched his colleciion by the addition of a number of tropical plants. After an absence of fifteen months Sloane returned to London; became Physician to Christ's Hospital in :694; married the daughter of a wealthy alderman in 1695 ; becane Secretary of the Royal Society in I693, a vice-president in I7I2, and president in I727; was created a baronet in I7I6; became president of the Royal College of Physi. cians in I7I9; and was appointed Physician to the King in I727. Sir Hans Sloane continued as president of the College of Physicians until I735, and died in I753. At his death his collections of plants and other objects of Natural History, together with his library and MSS., were purchased by the nation for $\delta_{20,000}$. These collections formed the nucleus of the British Museum, opened in I759. Sloane was the author of a work entitled the "Natural History of Jamaica," in which he adopted the classification of Ray. He also contributed several papers to the "Philosophical Transactions." Sloane had four children ; two of these, both daughters, "survived their parents, and carried their wealth to the noble families of Stanley and Cadogan." For a critical estimate of this remarkable man, who was at once a fashionable physician and scientific dilettante, see "Encyclop. Brit.," 9th Ed., Vol. XXII, p. I60. 
aging and enabling the said Society to support the charge thereof, for the manifestation of the power, wisdom, and glory of God in the works of the creation, and that their Apprentices and others might better distinguish good and useful plants trom those that bore resemblance to them, and yet were hurtful, and other the like good purposes." $\quad$ These objects had already been aimed at by the Society, but the garden had also been utilized up to this time for the cultivation of medicinal plants to be converted into drugs for the Society's use. By the present deed the latter practice was prohibited. Among the other important conditions of the grant were the following :- $£ 5$ per annum were to be paid to Sir Hans Sloane or his heirs forever; "fifty specimens of distinct plants, well dried and preserved, which grew in their garden the same year, with their names or reputed names," were to be delivered yearly to the "President, Council and Fellows of the Royal Society of London" until the number of two thousand had been attained, and "those presented in each year" were "to be specifically different from [those of ] every former year ;" no other buildings but those legitimately connected with a physic garden were to be erected, but the bargehouse was allowed to remain. In the case of non-fulfilment of these conditions by the Society of Apothecaries, Sir Hans Sloane or his heirs were empowered to enter into possession of the garden and to hold it in trust for the benefit of the Royal Society, or, failing this, of the Royal College of Physicians, on conditions similar to those imposed on the Society of Apothecaries. Power was also reserved for the President and Vice-President of the Royal Society and of the Royal College of Physicians to visit the garden "once or oftener in every year" to ascertain whether the conditions specified were "duly observed and complied with" by the Society of Apothecaries. These conditions have, on the whole, been faithfully complied with by the Society, but payment of the annual rent does not appear to have been enforced by either Sir Hans Sloane or his heirs. The annual delivery of plants to the Royal Society seems to have taken place at irregular intervals, but the condition as to number was more than fulfilled, for with the last presentation, in I794, a total of (at least) 2550 specimens had been attained.

1 This passage, although placed in inverted commas, has, for convenience, been transferred from the present to the past tense. 
The members of the Society having come into permanent possession of the garden, they directed their energies toward its reorganization. A committee was appointed for the purpose of administration, and, on the recommendation of the committee, the gardener then in charge was dismissed ${ }^{1}$ and Philip Miller chosen in his place. The post which the latter so honorably filled was occupied uninterruptedly until 1887 by the following in succession: Philip Miller, F.R.S. (I722-I770); William Forsyth, F.L.S. (1770-I784); John Fairbairn (I784-I8I4); William Anderson, F.L.S. (I814-I846); Robert Fortune (I846-1848); Thomas Moore, F.L.S. (I 848-1887). The title of "Gardener" was changed to that of "Curator" during William Anderson's term of office.

The funds necessary for the re-arrangement of the garden and the repair of the buildings which it contained were raised by means of fees imposed upon the freemen of the Society and by an annual grant from its corporate funds, while the Royal College of Physicians assisted with a gift of $£ 100$. In 1724 , on the recommendation of the Garden Committee, the Demonstrator of Plants, Isaac Rand, F.R.S., was appointed Director of the Garden or Prefectus Horti, his duty in the latter capacity consisting in the superintendence and frequent inspection of the garden, while as demonstrator he was required "to attend in the garden during the six summer months, at least twice in each month, to demonstrate the plants to such as should then attend, and to execute such other matters as were by former orders enjoined." This office, like that of the gardener or curator, was held uninterruptedly for a considerable period, and the following filled the post in succession until its abolition in I 853: Isaac Rand, F.R.S. (to I 743); Joseph Miller (I 743-I747); John Wilmer (I748-I 764); William Hudson, F.R.S. (I765-I77I); Stanesby Alchorne (Honorary) (I77I-I772); William Curtis, F.L.S. (1773-I777); Thomas Wheeler, F.L.S. (I778-1820); James Lowe Wheeler (I 82 I-I 834); Gilbert Thomas Burnett, F.L.S. (I835); Jolin Lindley, F.R.S. (I835-I853). James Lowe Wheeler was the first Demonstrator of Plants to whom the title of "Professor of Botany"

1 Tradition had it that he was Philip Miller's own father, but Mr. Barrett has discovered an entry in the Society's records giving his name as Charles Gardiner. Henry Field, writing in IS20, made the statement that the records of the Society were silent upon the subject. 



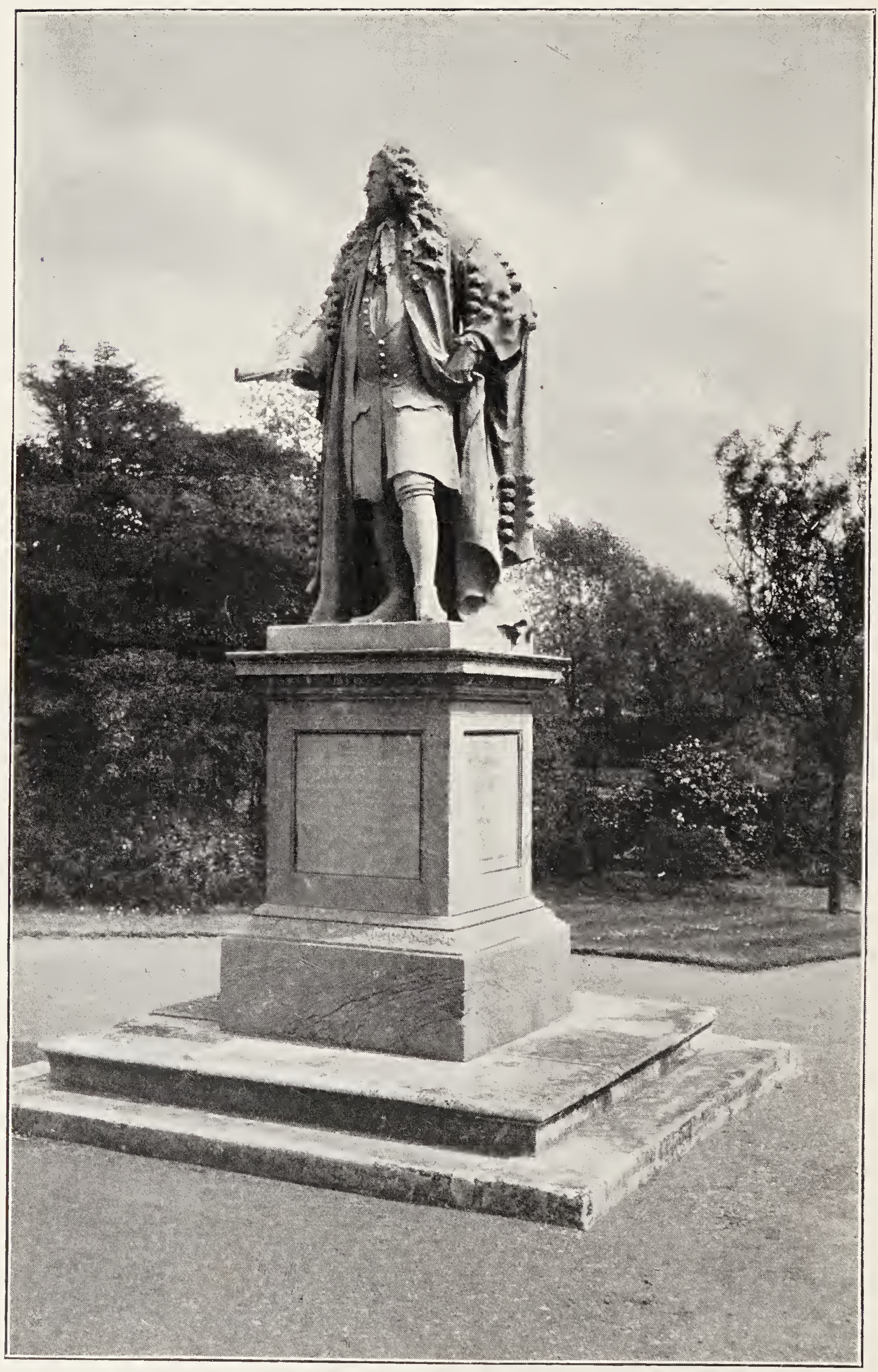

Statue of Sir Hans Sloane, in the Chelsea Physic Garden. 
was applied, but the terms "Professor" and "Demonstrator" were for some time used conjointly.

In 1732 important additions to the equipment of the garden were begun. These additions, consisting of a greenhouse and two stoves (see "I," " 2 ," and " 3 ," Plate XXV), were completed within two years; the expenses incurred in the undertaking were met by subscription among the members of the Society, and by a contribution from the Corporation. The first stone was laid by Sir Hans Sloane, and, in the following year, it was decided to erect a statue of him in the garden. This statue, the work of Michael Rysbrach, was completed in 1737 and placed in a niche in the front wall of the greenhouse. It was removed in 1748 to the position it now occupies in the centre of the garden and placed upon a pedestal which, like the statue itself, is of marble (see Plate XXIV). The following inscriptions were engraved on the pedestal in $175 \mathrm{I}:^{1}$

HANS: SLOANE Bar : Archiatro

Insignissimo Botanices Fautori

Hoc honoris causa Monimentum.

Inque perpetuam ejus memoriam.

Sacrum voluit

Societas Pharmacopœior: Londinens :

MDCCXXXIII.

THEY

Being Sensible how necessary

that Branch of Science is

to the faithful discharging the Duty

of their Profession,

With gratefui Hearts

and general Consent

Ordered this Statue to be Erected

In the year of our Lord 1733 ,

That their Successors and Posterity

may never forget

their Common Benefactor.

Placed here in the Year 1737.

Sr. Benjawin Rawling, Knt. Master

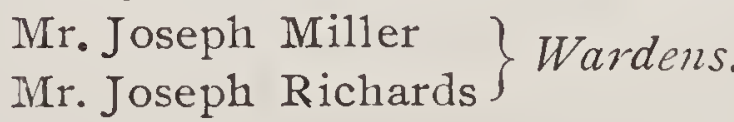

I According to Barrett the Latin inscription which was to be cut on the statue of Sir Hans Sloane was finally decided upon on August 22, I77 I, and its terms are inserted in the minute-book in full. 
Through Philip Miller's exertions the garden continued tc prosper, and we learn from a committee report of 1750 that it had been carefully examined in that year by the members of the com. mittee and found to be in very good order. The expenses of the garden, however, were also increasing, and the strain upon the Society's resources became so great that the Master and Wardens in I753, the year of Sir Hans Sloane's death, consulted the President of the Royal Society on the subject, but apparently without result. The difficulty was, nevertheless, tided over, and, after 1770 , the expenditure continued to advance steadily. During Lindley's tenure of office as Professor and Director it became more than doubled, and ultimately proved too great a burden for the Society to bear. In 1853 economies were effected which will be considered presently, and, in I 860, the Royal Society and the Royal College of Physicians were both approached by the Society of Apothecaries with a view of surrendering the garden to one of them. The offer was refused by these bodies, and it was not until 1899 that the Society was able to free itself from the garden and to pass it over to other hands.

The following is an epitome of the principal improvements carried out in the garden during the period which we have just considered: In I77I the garden was embanked on the river side to reclaim ground that had been encroached upon, and in the following year a rockery was constructed from materials presented by Stanesby Alchorne, John Chandler and Sir Joseph Banks. In I787 a quantity of loam was brought from Sion and "black mould" from Wimbledon, and shortly after the appointment of William Anderson in I 814 it is once more on record that the garden was in excellent order. This satisfactory condition of things appears to have occurred periodically with the advent of a young and energetic gardener, and to have waned with the advancing age of the latter. We accordingly find that when Lindley became Director of the Garden he reported it to be in a very unsatisfactory condition, and it was only by bringing considerable pressure to bear on Anderson that comparative order was restored. During Robert Fortune's short tenure of office as gardener (I 846-I 848) improvements were energetically prosecuted, and this policy was continued by his successor, Thomas Moore, until 1853 ; but between the latter date and 1862 the garden went from bad to worse, owing to insufficient funds. A slight revival took place in $\mathrm{I} 863$, but the garden was in a moribund condi. 
tion, and after Thomas Moore's death there is nothing of importance to record until its transfer to other hands. In I 870 the construction of the Chelsea embankment was contemplated by the Metropolitan Board of Works. By mutual agreement between the Board and the Society, the latter lost the foreshore of the garden as well as access to the river, but obtained certain benefits in return, including the present wall, railing, and main gates which face the embankment. Turning now to the particulars of the plant houses and other buildings, we find that the greenhouse, erected in $1732-34$, was in 1747 already in need of repairs, and with the assistance of a contribution from Sir Hans Sloane these were duly carried out. In I779 a new small stove was built to take the place of an old one, and we learn that in 1785 the greenhouse required slating, as well as other repairs to glass lights. The expenses involved in this work were defrayed by subscription among the constituents of the Society. Two new stoves were erected in I 789, a new tan-pit in I790, another in I79I, and a new dry stove in 1 y92, to take the place of a ruined one. Several alterations were begun in 18 I 5 and completed in the following year. These included improved heating arrangements, which involved the addition of a room behind one of the greenhouses to provide sleeping accommodation for the gardeners, in order that the latter might be near the fires. A pump for Thames water was also provided in the same year, as the spring water which had hitherto been used was said to be injurious to the plants. The improvements carried out during Fortune's curatorship comprised "two new span-roofed glass structures, a stove and a greenhouse." In these the "Polmaise" or hot-air system was tried, but found unsatisfactory, and two years later heating by hot water was substituted in its stead. The expense was met, as usual, by subscription among the members and by a grant from the Corporation. In 1853 one of the glass houses was taken down and sold, but one stove was retained, for although it had been proposed to suppress artificial heat altogether in the houses, it was found that some "medicinal plants which were absolutely necessary required heat." 1 In I 863 the plant-houses were re-arranged and new ones constructed, and into some of these Wardian cases were introduced. It was not until the

${ }^{1}$ Cf. Barrett's "History of the Society of Apothecaries," from which the above statement is quoted. 
new rigime, however, that the hothouse collections became at all considerable in extent.

The only other buildings of sufficient importance to be considered here are those which served as a residence for the gardener or curator. Apartments in the greenhouse were provided for the gardener almost from the first. In I761, however, Philip Miller made the request that he should be provided with a dwelling in the garden, so that the rooms in the greenhouse were evidently 110 longer habitable, and it is not until the appointment of William Forsyth as gardener in I770 that we hear of "lodging-rooms in the greenhouse" being provided once more. John Fairbairn, on his election to the office of gardener, in I784, was directed "to make the apartments over the greenhouse his residence," and his successor, William Anderson, was granted "the usual apartments for his residence." The construction of a sewer in I 853 rendered the building unsafe, and a new house for the curator was erected on the site of "the old lecture-room." 1 This new building remained until the surrender of the garden by the Society of Apothecaries.

It will not be without interest at this point to refer briefly to the barges and barge-house which figured prominently in the early history of the garden, although the matter is of no botanical interest. Three barges were successively owned by the Society. The first was built in 1675 , the second in 1727 and the third in 1764 . This last was sold in I8I7. Between I7I7 and I727 the apothecaries were without a barge, and they accordingly "entered into treaty with the Stationers' Company for their barge-house at Chelsea." 2 In I 8 I 8 the barge-house "was let on lease to Mr. Lyall, of the Swan Brew-house, for twenty-one years," and after his tenancy no more is heard of it.

1 This formed part of the same building as the old greenlouse and residence of the curator, the whole constituting the "Green House" erected in I732-4, and indicated in Plate XXV by figure "I." The building is also seen in the distance through the gateway in Plate XXII.

${ }^{2}$ The references to this barge-house in Henry Field's "Menoirs" and in Mr. Barrett's work are very confusing. It is certain, however, that more than one barge-liouse was owned by the Society, inasmuch as two barge-houses, in addition to the one which the Society itself occupied, are mentioned in the Society's records, and details are given in the latter of varions agreements relating to the tenancy of the houses by the 'Tallowchandlers', WVeavers', Coopers', Vintners' and Goldsmiths' companies. 'The existence of these three barge-houses is furtler confirmed by the old print reproduced on Plate XXV. 


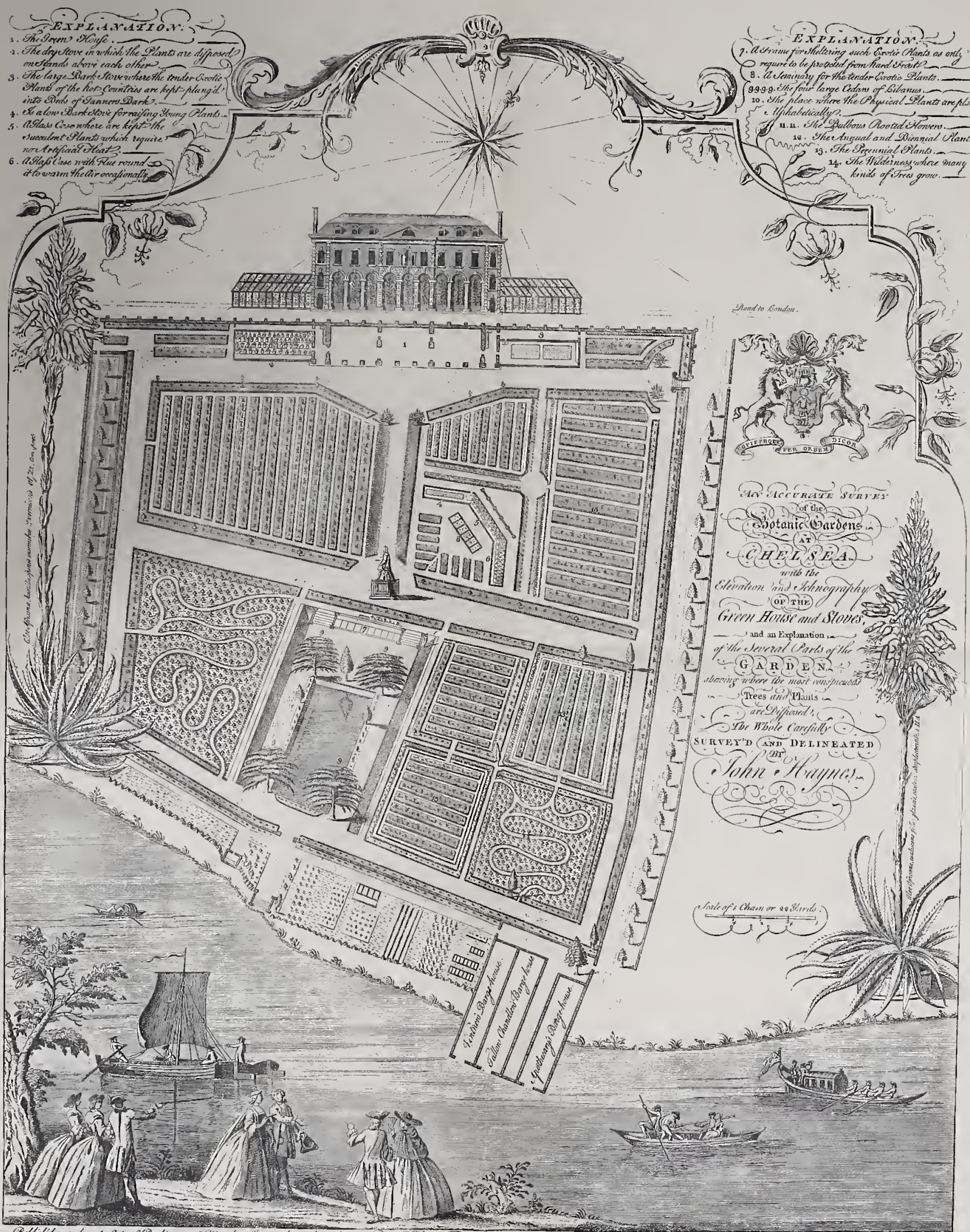

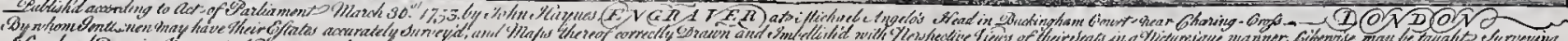

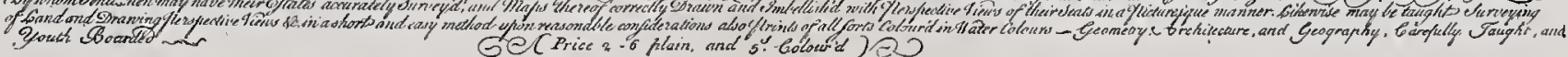



The steps taken to form a library and herbarium in connection with the garden may also be conveniently considered here. The first indication of the Society's intention to form a library for the garden is found in one of the Society's minute books under the date of October 6, I68 I, where it is recorded that it was then determined to " contrive a library" for the use of the laboratory and garden.

Samuel Dale, a member of the Society," who died in I739, left a legacy of books and dried plants to the Society on condition that the Master and Wardens should, within twelve months after his decease, "make or erect proper conveniences in their Physick Garden at Chelsea, for the reception thereof." Presses were accordingly made for their accommodation, and an inscription was placed over the collection to indicate that it was the gift of Dr. Dale. ${ }^{2}$ The collection of books in the Chelsea Garden was increased in I744 by the addition of a number of botanical works, the gift of the executrix of Isaac Rand. From a catalogue prepared by Stanesby Alchorne in 1769 , it appears that there were in that year at the garden 266 books, mostly on botanical subjects, and about 50 unbound books and pamphlets. According to this same catalogue, there were also 238 volumes in the older library at the Apothecaries' Hall, but many of these had originally formed part of the garden library, and had been removed to the hall on various occasions. This process seems to have continued until the whole of the collection of books at the garden became absorbed by the Hall Library, for it was found

1 This is on Field's authority, but Prof. G. S. Boulger, in an able account of Dale contributed to The Joumal of Botany, Vol. XXI (I883), pp. I93-I97 and 225-23I, has shown that the statement is probably incorrect. Professor Boulger says: "He was apprenticed on the 5 th of May, 1674, as the "son of North: Dale of ye parish of St. Mary Whitechappell in County Middlsx. silk-thrower . . . to Thos. Wells for 8 yeares;' but as he seems never to have practised as an apothecary in London it was not necessary for him to take out his freedom as a member of the Society of Apothecaries, and he seems never to have done so."

2 "In the Gentleman's Magazine he is described at his death as Dr. Samuel Dale, F.R.S. ; and many notices of him speak of his being a Licentiate of the Royal College of Physicians. He, however, seems never to have received or used the title of M.D.; his name does not occur in Dr. Thomson's list of the Fellows of the Royal Society, nor in that by Dr. Munk of the Iicentiates of the College of Physicians. There is, in fact, no reason to suppose that either of these three titles has been rightly applied to him." - Boulger, loc. ciz.. p. 229 . 
necessary in I 863 to furnish " the rooms of the assistant gardeners with suitable books and specimens for the instruction of these officials."

Dale's herbarium was supplemented in 1745 by a donation of I 2 volumes of dried plants from Robert Nicholls. These were deposited in the greenhouse, and, in I748, 22 similar volumes were presented to the Society by Joseph Miller's widow. Isaac Rand's herbarium was also bequeathed to the Society, and in I759 Mrs. Rand gave a sum of $£ \mathrm{I} O \mathrm{O}$ to be held in trust for its repair. That is to say, two-thirds of the annual interest was to be paid to the Demonstrator for the time being “for placing twenty newly dried specimens of plants yearly, in her late husband's collection, in room of such as might be decayed," while the remaining third of the interest was allotted " to the Master and Wardens for seeing it done." In Stanesby Alchorne's catalogue of I769 the Hortus Siccus of Joseph Miller was stated to consist of 20 volumes. A "bundle of dried plants," the gift of John Wilmer, is also mentioned in this catalogue, but there is no reference in the latter to Isaac Rand's collection. William Hudson bequeathed his herbarium to the Apothecaries' Society at his death in I 793. In I 806 this collection was presented to Thomas Wheeler, who was then Demonstrator of Plants, and, finally, in I 862, the whole of the herbarium specimens at the Chelsea Garden was presented to the trustees of the British Museum. The most important of these collections is undoubtedly that of Samuel Dale, owing to the fact that it contains the original herbarium of John Ray, who had bequeathed it to his friend Dale.

Having now considered the main features of interest in the maternel of the garden under the Society's rule we may conclude this first section by amplifying our account of the administration of the garden during that period.

It has already been stated that when the Society of Apothecaries came into complete possession of the garden in I722, a special committee was appointed to administer the latter. This committee originally consisted of the Master, the two Wardens and nine other members of the Court of Assistants. The same constitution as to number of members obtained until 1776 , but in 1752 three of the members were ordered to be changed every year. In 1776 the Court of Assistants directed that every member of that court who had served the office of master should be a standing member of the 
Garden Committee. The number of members on this committee was further increased in 1784 by the addition of three members of the Livery, and this appears to have been the last change made in the constitution of the Garden Committee. The services of the members of the committee were, so far as can be ascertained, gratuitously rendered at first, but in 1776 it was directed that each member should be allowed five shillings for every attendance. Refreshments were also provided at the Society's expense, and, in I780, the sum of $£ 5$ was fixed as the allowance for refreshments at each meeting. In $\mathrm{I} 8 \mathrm{I}$ o the regular meetings were ordered to be held in April, June, August and September, and the "refreshments" at the meetings eventually took the form of dinners held in the garden. In I 853 both the fees and the dinners were abolished, and even the Garden Committee itself ceased to exercise its functions for a time. Indeed, although the Garden Committee is said to have resumed its proceedings after a short interval, there is little evidence to show that it was in existence until I 862 when it was galvanized into a semblance of life, chiefly through the efforts of Nathaniel Bagshaw Ward. After Ward's death in I 868 we again look in vain for evidence of life in the Garden Committee, and most of the administrative work appears to have been undertaken by the Court of Assistants.

The rules framed by the governing body for observance by the Demonstrator of Plants and Prefectus Horti are among its most important enactments, and we will now proceed to consider them. The duties of the office of Demonstrator of Plants had, as we have seen, been defined in general terms on the appointment of Isaac Rand to that office in I724, but it was not until I773, when William Curtis was elected to the post, that these duties were set forth in detail. This set of instructions has already been referred to elsewhere, and several of its clauses have been dealt with in detail. The terms of the remainder still remain to be considered, and were as follows:-

"The office of Botanical Demonstrator to this Society, is to superintend their garden and gardener, as also their library, and all other matters upon their premises at Chelsea; but with submission always to the superior direction of the General Committee for the management of the Society's Garden. His duty is to encourage and cultivate the knowledge of Botany, theoretic as well as practical, among the students of this Society; for which purpose, 
" - He is to attend the Society"s Garden at stated times, not less than once in every summer month, (from April to September, both inclusive) to demonstrate the plants, especially in the officinal quarter, with their names and uses. The last Wednesday in each of the above months has been usually appropriated to this service, beginning at nine of the clock in the morning.

"— He is yearly to prepare fifty dried specimens from plants, growing in the Society's garden at Chelsea, which are to be presented to the Royal Society, by direction of the late Sir Hans Sloane, Bart. having been first approved by the Court of Assistants of this Society. Also to dry twenty other specimens, in lieu of so many plants which shall be found decayed in the collection of the late Mr. Rand, now in the library at Chelsea. These to be placed in the said Herbarium before the first day of May in every year, and there will be fifty shillings paid him for every such service, by appointment in the will of the late Mrs. Rand."

The rules of 1773 , with the exception of the last-mentioned paragraph, do not seem to have undergone any alteration until the election of James Lowe Wheeler as Demonstrator and Prefectus in I $\$ 2$ I, when some slight amplifications were introduced. The Demonstrator was required, as in the minute of 1773 , to give demonstrations in the garden on the last Wednesday of each summer month, but it was further stipulated that he should on each such occasion, or on other occasions if so directed, employ some time "in explaining to the students the systems of Botany, both Sexual and Natural, as taught by Linnæus and Jussieu; together with the principles of vegetable life, and the Structure, Physiology, and Medical Virtues of Plants, their Natural Climate, the alterations produced by culture, and the parts of them employed whether medicinally or as food for man and other animals." With the exception of a few other suggestions, however, the new instructions were substantially the same as the old ones. But a new order of things was being created by the Act of I 8 I 5 , in that membership was not incumbent upon the new licentiates of the Society, and these unaffiliated licentiates, as well as students preparing themselves for the license, were rapidly increasing in numbers. The demonstrations and herborizings, however, were confined to members or their apprentices, so that this growing class of students and qualified non-members was placed at a considerable disadvantage. The advisability of remedy- 
ing this state of things gradually impressed itself on the members of the Garden Committee, and, in I 829, it was suggested by them that the garden might be made more useful to the profession generally than it had hitherto been. They recommended that the garden should be opened weekly on Fridays between 9 and II in the morning, dating from the third of July of that year, "to all such Medical Students as were pupils to the established Professors and Tutors in the Metropolis in Medicine, Chemistry, Materia Medica, or Botany." This was accordingly done, and a ticket of admission was issued to every metropolitan medical student who brought a letter of recommendation from his teacher. More than Ioo pupils having taken advantage of the facilities offered to them by the Society, the Garden Committee in December of the same year presented a further report to the "Master, Wardens, and Assistants of the Society of Apothecaries" embodying the following recommen. dations :-

"That the Garden be open every Wednesday during the months of May, June, July, August, and September, from 9 o'clock in the morning until 12 at noon, and that admission be given to all such medical students as are pupils to the established professors and lecturers in the metropolis, whether in Medicine, Chemistry, Materia Medica, or Botany, and also to the Apprentices of the several Mem. bers of the Society.

"That there be every week a demonstration of all the piants contained in the Materia Medica department of the Garden, and of such other plants as the Demonstrator may think proper. Such demonstration to commence at io o'clock punctually, and that after such demonstration is finished there be a lecture delivered by the Demonstrator in some part of the building attached to the Garden, upon one or more of the following subjects, so as to form during each summer season a regular Course of Botanic Study, namely,-

“( I) The different systems of Botany, both natural and artificial, particularly those of Linnæus and Jussieu.

“(2) The Structure and Growth of Plants.

"(3) The different parts of Plants, with their description and uses in the process of Vegetation.

"(4) The natural and chemical analysis of vegetable matter.

"(5) The medicinal uses of the most important articles in the 
Materia Medica, with observations on the best modes of preparing them. These remarks may be made either at the lectures or at the demonstrations, at the discretion of the lecturer.

"That the conducting these demonstrations and lectures be committed to the Society's Demonstrator of Botany, and that the monthly lectures hitherto delivered by him at the Garden be discontinued, as merging in and more effectually provided for in the lectures now proposed to be adopted.

"That in consequence of the additional service occasioned by these lectures the salary of the Botanical Demonstrator be increased."

These recommendations were adopted, and the new rules came into operation in the following year. When Lindley became Prefectus Hort and Professor of Botany the number of lectures in the garden was increased, a lecture being delivered twice a week at 8.30 A.M. in May, June, and July, instead of one weekly at IO A.M. from May to September. Other suggestions as to the re-arrangement of the plants and the preparation of a catalogue were also made by Lindley, and these were readily acted upon by the Society. Lindley, in a word, may be said to have dictated terms which were at once acceded to, so that the entire management of the garden was virtually in his hands until the suppression in 1853 of the office of Director of the Garden, which he was the last to hold.

We have seen that the regulations of 1773 had placed the gardener in a subordinate position. This arrangement seems to have worked smoothly on the whole until the advent of Lindley, when submission to the Prafectus Horti was enforced on Anderson, who was gardener at the time. After the abolition of the office of Prefectus Horti, the gardener, then known as the curator, was entrusted with the management of the garden, subject, of course, to the higher authority of the Society's governing body. The inadequate remuneration of the gardener seems to have been a cause of much complaint on the part of that functionary. In 1767 Philip Miller presented a memorial to the Court of Assistants showing that his expenses in connection with the garden were not covered by his salary, and a gratuity of $£ 50$ was accordingly granted to him in the following year. Forsyth, in I774, also complained that his salary was insufficient, and, in order to supplement this, the vicious principle was introduced of allowing him to sell supernumerary 
plants for his own profit. Before leaving this topic there are a few other administrative matters connected with the office of gardener which merit some notice. Thus we learn that in I 744 "an order was made that no person be permitted to gather specimens from the garden without leave from the director or gardener, and that no person whatever, who was not a member of the Society, be perinitted to walk in the garden without the attendance of the gardener." It is apparent from this that the public had been admitted to the garden, and there is also evidence to show that the precautions just mentioned were taken because of some act of vandalism by a visitor. By I 786, however, the members had become so numerous that it was a difficult matter for the gardener to recognize them all, so that "an engraved card suitably ornamented, and endorsed by the Master and Wardens for the time being, was directed to be given to every present and future member, to which the gardener and his servants were to pay due regard." The importance of the gardener's services was also recognized by others besides the members of the Society of Apothecaries and the general public, for in 18 I 5 the Horticultural Society requested that they might be allowed to make experiments in the Chelsea Garden under the control of the Society of Apothecaries and its gardener. This request was refused, but permission was accorded to the gardener to make such experiments, provided that application was made by the Horticultural Society through the Garden Committee, and a portion of the garden was accordingly set aside for "the planting of various fruit trees and esculent vegetables."

It has already been mentioned that the normal expenses incurred in administering the garden were met, as early as I 7 I 3 , by the imposition of fines on the Society's constituents. It has also been shown how this arrangement was disturbed in succeeding years owing to the unsettled condition of the garden. After the transfer of the property to the Society of Apothecaries by Sir Hans Sloane the system of levying definite fees upon the Society's members was again introduced, and this, together with additional grants from the Corporation, was the method adopted during the whole period in which the garden was owned by the Society of Apothecaries. It will, further, be remembered that extraordinary expenses were met, in the early days of the garden's history, by subscriptions among the members of the Society, and by special grants from the Cor- 
poration. This system was also the one subsequently adopted on similar occasions.

The awarding of prizes for proficiency in botanical subjects is intimately connected with the administration of the garden, and a short account of the steps taken by the Society in this direction will form a fitting prelude to the next section of our subject, namely, the Botanical work accomplished in the garden. Prizes in Botany were offered by the Society to their apprentices at least as early as I789, but it was not until I 830 that the scope of the examinations in Botany and Materia Medica was extended so as to include external students. The recommendations of the Garden Committee adopted in 1829 have already been considered in some detail in connection with the duties of the Demonstrator of Plants. The following clauses relating to the examination of candidates and to the awarding of prizes complete the main provisions of the report in question:

"That in order to give encouragement to diligence and talent, there be an annual examination of such students as may think proper to become candidates for the prizes intended to be given on these occasions. The examinations to be upon some or all of the subjects stated in the foregoing series of lectures (see pp. 67, 68), as well as upon their skill in the nomenclature of plants. No person to be admitted a candidate who has not attended these lectures and demonstrations at least eighteen days in one summer, or thirty days in two succeeding summers, nor shall any prize be awarded unless his examination be performed to the complete satisfaction of the examiner or examiners for the time being.

"To prevent partiality or undue preference, no public professor or lecturer whose pupils are admitted to the Garden can be appointed an examiner.

"The apprentices to Members of the Society having an annual opportunity of being candidates for prizes upon the ancient establishment, cannot be admitted candidates on these occasions either during the period of their apprenticeship, or subsequently to the conclusion of it.

"That two medals, the one being of gold of ten guineas value, and the other of silver or bronze, be annually awarded to the two candidates who shall have passed the best and second best examination in manner hereinbefore mentioned, but no medal to be given 
unless in the opinion of the examiner or examiners the candidate shall be deemed deserving of it."

The recommendations were adopted, and, in conformity with them, three prizes were awarded at the termination of the session in I 830; two to medical students at large, and one to the apprentices of the Society. The two examinations for these classes of students were fused into one in 1837 , and a modification in the prize-awards was introduced at the same time: the best candidate was to receive a gold medal, the second a silver medal with books, and the third books only. In I 853 these prizes were discontinued, but renewed after a short interval. James Lowe Wheeler, David Don, Nathaniel Bagshaw Ward, Sir J. D. Hooker, and the Rev. Miles Berkeley successively held the post of examiner for prizes in Botany, while the following well-known names may be selected from the roll of successful candidates: Thomas Henry Huxley, Maxwell Tylden Masters, John Harley, Charles Hilton Fagge, Henry Trimen, and Henry Charlton Bastian.

THE WORK ACCOMPLISHED IN THE GARDEN, DURING THE ADMINISTRATION OF THE SOCIETY OF APOTHECARIES.

In the introductory chapter a summary was given of the botanical work accomplished by the Apothecaries in their garden at Chelsea, and from this we have seen that it was mainly of an educational character. The various systems of classification, for example, from that of Ray downwards, were reflected in the arrangement of the plants in the garden, and this practical application of one system or the other was preceded, as a rule, by its adoption in the lectures and demonstrations, and foreshadowed in many notable contributicns to scientific literature by prominent apothecaries or by members of the garden staff. These important matters will be considered in greater detail presently, but it will be expedient, in the first place, to trace the steps by which the collections of plants were developed.

One of the earliest references to the contents of the Garden is to the effect that in 1678 a good crop of herbs for the use of the Laboratory was furnished from the garden, and it is also on record that directions were given, in the same year, to have the garden planted with the best varieties of fruit trees. In the autumn of I682 "Dr. Herman, of Leyden, visited Chelsea Garden, and pro- 
posed an exchange of plants, which proposal Mr. Watts went to Holland to carry into effect." The system of exchange thus inaugurated became the most important factor in developing the collections at the Chelsea Garden, and from Pulteney's "Sketches" we learn that during Philip Miller's curatorship "it was the remark of foreigners, that Chelsex exhibited the treasures of both the Indies." These acquisitions of rare plants are mentioned by the Garden Committee in I 750, and credit is given to Philip Miller for his "great diligence in settling a correspondence, and procuring seeds and plants from various parts of the world." In I77I and $\llbracket 772$ "a great interchange of exotic plants took place between the Society" and a number of "Noblemen, Gentlemen and others." "Her R. H. the Princess Dowager's garden at Kew" is mentioned among the contributors, and we also learn that "a bag of seeds was presented by Joseph Banks, Esq., and Dr. Solander." The influence of Philip Miller is here clearly perceptible, as Aiton who had charge of the Princess Augusta's garden at Kew was, as we have already seen, a former pupil of his, while Banks is also said to have received his early training in botany at Miller's hands. The policy so zealously pursued by Philip Miller was vigorously maintained by the Society after his death, and we accordingly find that the Demonstrator of Plants was, by the rules of $\mathrm{I} 773$, "earnestly recommended" to "cultivate an extensive botanical correspondence both at home and abroad." It is evident that this recommendation bore fruit, for extensive accessions of plants and seeds from various parts of the world are recorded in 1778,178 I, I 790, I 793, and I809. In I 815 the Court of Assistants determined "to advance" the garden "to as high a rank in the scale of exotic gardening as the ... improved state of that science would require," and with the cooperation of William Anderson, the new gardener, steps were taken to bring about the desired result. During Lindley's tenure of office as Professor of Botany and Prafectus Horti the collections were doubtless maintained at a high level of excellence, although it must be confessed that details are wanting on this point. The appointment of Robert Fortune as curator in I 846 was attended with fruitful results, and the mention of his name brings us to a subject of cardinal importance in the history of the cultivation of exotic plants. Fortune, before his appointment as Curator at the Chelsea Garden, had held the post of Botanical Collector to the Horticultural Society 
of London. In that capacity he had just returned to England from China, and during his three years' exploration of the latter country he had enriched the Horticultural Society's gardens at Chiswick with a large number of valuable plants. "Wardian Cases" were used by Fortune for transporting to England the living plants which he had collected in China, and to this application of Ward's discovery the great success of Fortune's mission was largely due.

Some of the services which Nathaniel Bagshaw Ward, F.R.S., rendered to the Society of Apothecaries have already been mentioned in the preceding pages. We have seen, for instance, that he held the post of Examiner for Prizes in Botany from I 836 to I854, and that he was the prime mover in the renewal of activities at the Chelsea Garden in I 863. But Ward's scientific and administrative work was not limited to this, for he was one of the founders of the Royal Microscopical Society, established in I840, and in I 854 he became Master of the Society of Apothecaries. During his year of office as Master he gave "on a very large scale" at the Apothecaries' Hall "two microscopical soirées, which have never been surpassed either there or elsewhere." His name, moreover, will always be associated with the discovery of the fact that plants which would otherwise perish in a smoky atmosphere, such as that of London, could be made to thrive if placed in "closely-glazed cases." This discovery was first made known to the world in a letter to Sir William Hooker which appeared in the "Companion to the Botanical Magazine" for May, I 836, and details of the cases and their various applications were published in I842 in a little work of 95 pages entitled "On the Growth of Plants in Closely Glazed Cases: by N. B. Ward, F.L.S." The fourth chapter of the work "on the conveyance of plants and seeds on ship-board" is the one of most interest to us, as Ward here gives an account of several experiments in which the transport of living plants had been successfully accomplished by the use of the cases he had invented. The first of these shipments was made "in the beginning of June, I833," when two cases filled with "ferns, grasses, etc.," were sent to Sydney, N.S.W., in the charge of Capt. Charles Mallard, R. N., with the following result :-

"SYDNEY, January I8, I834.

"Sir:-I have the happiness to inform you that the plants contained in the two glazed cases entrusted to my care, were landed here at the Botanical Garden about three weeks ago, nearly the whole of them alive and flourishing. 
They have since been transplanted by Mr. McLean, who has charge of the garden in the absence of Mr. Cunningham (gone to New Zealand botanizing), and all are doing well.

"The complete success of your interesting experiment has been decidedly proved; and whilst offering you my congratulations upon this agreeable result, I cannot but feel some little degree of pride and pleasure in having been the instrument selected to put to the proof so important a discovery to the botanical world.

\section{"To N. B. Ward, Esq."}

"I am, Sir, etc., etc.,

"Charles MaliaRd."

It was Fortune, however, who first demonstrated on a large scale the value of the Wardian case in transporting living plants, and the revolution which this means of transport brought about is made evident in the following passage:-

"Eighteen glazed cases filled with the most beautiful plants of tiorthern China were placed upon the poop of the ship, and we sailed [from Canton] on the $22 \mathrm{~d}$ of December [ $\mathrm{I} 845]$. After a long but favourable voyage, we anchored in the Thames, on the 6th of May, I846. The plants arrived in excellent order, and were immediately conveyed to the garden of the Horticultural Society at Chiswick," 1

As a contrast to this we have it on record that in I 8 I 9 only one plant in a thousand had survived a similar voyage under the old conditions.

In I 848 Fortune resigned the post of Curator of the Chelsea Physic Garden to enter the employ of the East India Company. His success in introducing the tea-plant into India for the Company is a matter of common knowledge, as is also Markham's feat with cinchona; and both of these achievements were only made possible by the application of Ward's discovery. ${ }^{2}$

After Ward's death, in I 868, the work of the garden languished owing to insufficient funds, and although Thomas Moore, the Curator, did his best and appealed to correpondents at home and abroad

1 “'Three years' Wanderings in the Northern Provinces of China, including a visit to the Tea, Silk, and Cotton Countries : with an account of the Agriculture and Horticulture of the Chinese, New Plants, etc., by Robert Fortune, Botanical Collector to the Horticultural Society of London." London, I 847 , p. 405 .

${ }^{2}$ For a description of the cases used by Markham see his "Peruvian Bark. A popular account of the Introduction of Chinchona cultivation into British India," Irondon, ISSo, pp. 259-265, where a short comparison is also made with those that Fortune employed. 
for donations of plants, his efforts were only partly successful. The temporary improvement effected through the exertions of Nathaniel Bagshaw Ward thus suffered a gradual decline, which ultimately resulted in the practical extinction of activities at the Chelsea Garden.

The system of sending out collectors of plants never seems to have been adopted by the Society of Apothecaries, owing probably to the expense which it entailed, but there is an entry in 1732 to the effect that " $£ 20$ per annum be paid by the Society towards the expense of sending a person to Georgia, to collect trees and plants, and to make experiments concerning raising them in England, which sum was in the following year ordered to be paid to the trustees for that colony." Now that botanic gardens have been established in all parts of the world, the system of exchange inaugurated in 1682 at the Chelsea Garden has almost entirely superseded that of sending out plant collectors, and all botanic gardens of importance issue periodically lists of seeds or of plants for exchange.

Turning now to the matters which have been referred to in the opening paragraph of this section, we shall find much to interest us; for the history of botany, and especially that of Systematic Botany, in this country, is mirrored in that of the Chelsea Physic Garden.

Systematic Botany in England may be said to have originated with John Ray (if we except Robert Morison), and the system which he elaborated in his Historia Plantanum marks an era in the history of botanical science. ${ }^{1}$ Ray acknowledges as his collaborators Samuel Doody, who was associated with the early history of the Chelsea Garden, and James Petiver, the Society's first Demonstrator of

${ }^{1}$ It does not fall within the limits of this paper to enter into details of the different systems of classification, but the reader will find an admirable account of the latter in Asa Gray's "Structural Botany" or Part I of "The Botanical Text Book (Sixth Edition)." New York and Chicago, I88o, pp.33 I-344. This is a little masterpiece of conciseness and precision, as lucid as it is exact; but the student who is desirous of pursuing the subject further should consult the spirited but subjective account in the "History of Botany (I530-1860), by Julius von Sachs . Authorized translation by Henry E. F. Garnsey, M.A., revised by Isaac Bayley Balfour, M.A., M.D., F.R.S." Oxford, I89o, pp.3-2i 6 .

Engler's system has not been adopted, to my knowledge, in any of our Bctanic Gardens, so that the two above-mentioned works contain all that is necessary for our purpose. A comparison of Engler's system with that of Bentham and Hooker will be found in J. C. Willis's "Manual and Dictionary of the Flowering Plants and Ferns." Cambridge, I897, Vo1. I, pp. I33-I47. 
Plants. It is hence reasonable to infer that his system was reflected in the arrangement of the plants in the garden and in Petiver's demonstrations, but it must be admitted that this is largely a matter of conjecture. Suffice it to say, however, that Petiver was himself a contributor to the third volume of the Historia Plantarum, and that he adapted his writings to that work. We find, moreover, that Samuel Dale, the learned apothecary of Braintree, adopted Ray's system in his standard work, the Pharmacologia. But the influence of Ray's contemporary, Tournefort, was also making itself felt, and this is perhaps indicated by the fact that Philip Miller followed a neutral course in his catalogue, published in 1730 , of the officinal plants in the Garden. ${ }^{1}$ In this small book of ${ }_{5} 2$ pages the plants are divided into two sections, viz., (I) Herbs and Undershrubs; (2) Trees and Shrubs. Each section is arranged alphabetically, but copious references are given to the works of Tournefort and Ray, as well as to those of other botanists. Another catalogue covering the same ground was published in the same year by Isaac Rand, the Demonstrator of Plants. ${ }^{2}$ The author of this work does not even go to the length of dividing his list into two

${ }^{1}$ Catalogus Plantarum officinalium quae in Horto Chelseiano aluntur. London, I730. This contains the names of 499 plants -405 in the first section (Herbce et Suffrutices) and 94 in the second (Arbores et Frutices). It is written in Latin, but an English name is also given to each plant.

${ }^{2}$ Index Plantarum Officinalium, quas, ad Materice Medicce Scientiam Promovendam, in Horto Chelseiano, Ali ac Demonstrari curavit Societas Pharmaceutica Londinenșis. London, I73O. This catalogue is little more than a duplication of Miller's work, but it contains the names of 5 r S.plants as against Miller's 499, "aud specifies the part of each used in medicine." The appearance of these two catalogues in the same year is thus explained by Martyn, in the preface to his edition of Miller's Dictionary: "Mr. Rand, then Lecturer and Demonstrator to the Company of Apothecaries in their Botanic Garden, regarded this book of Mr. Miller's as an incroachment upon his province: he therefore published in the same year, Index Plantarum Officinalium Horti Chelseiani." Henry Field in his "Memoirs" omits all reference to Philip Miller's Catalogus, but refers to Rand's Index in the following terms : "I729. Mr. Isaac Rand laid before the Court of Assistants his 'Index Officinalis Horti Chelseiani ;' when one thousand copies were ordered to be printed at the expense of the Society. This was a catalogue of that part of the garden which was allotted to the culture of medicinal plants, shrubs and trees, contained in the Pharmacopœia of the College of Physicians; and was designed for the use of those Apprentices, who attended the Botanical Lectures at the garden." Per contra, Semple, in his revision of Field's work, mentions Philip Miller's Catalogus, but suppresses Field's reference to Raud's Index. This omission is probably 
sections, but he adopts the alphabetical arrangement throughout, and this non-committal attitude was also assumed in 1722 by Joseph Miller in his Botanicum Officinale, by Rand in his second Index (I739), and by Philip Miller in his Dictionary (from I724 until I759). The influence of both Ray and Tournefort is, however, clearly perceptible in these earlier editions of Philip Miller's Dictionary, that of Tournefort predominating. The old print of the garden published in 1753 , and reproduced on Plate $\mathrm{XXV},{ }^{1}$ throws a considerable amount of light on the disposition of the plants in the garden at that date. The arborescent plants are located together in two plots ("The Wilderness where many kinds of Trees grow"), there is a "place where the Physical Plants are placed alphabetically," the "Bulbous Rooted Flowers" have a section to themselves, the "Annual and Biennial Plants" occupy another section, and the "Perennial Plants" complete the list. Except in the case of the medicinal plants there is no indication given of the way in which these various groups are classified, but it is interesting to note that the division into arborescent and herbaceous plants is common to the systems of Ray and Tournefort, and that the "Bulbous Rooted Flowers" probably correspond to those of the twenty-first book of Ray's Historia Plantarum, "qui est De Herbis radice bulbosa donatis iisque affinibus." The section devoted to medicinal plants also suggests several points of interest. We find, in the first place, that this collection, which was by far the largest one at the beginning of the eighteenth century, now forms but a relatively small part of the varied contents of the garden, and we also perceive that the alphabetical arrangement which had commended

due to a confusion of the Index with a later catalogue by Rand entitled Horti Medici Chelseiani Index Compendiarius [etc.], and published in I739; for the author (Semple), in his description of the latter work, states that "it would appear from some pages in the biography of Mr. Philip Miller, that Mr. Rand prepared this Index in consequence of his feeling hurt at the publication of the Catalogue of the contents of the Garden by the former, who, as Mr. Rand considered, had encroached upon his province, he being the Præfectus Horti and Botanical Demonstrator while Mr. Miller was the Gardener." The confusion has doubtless arisen from the fact that the original "Memoirs" by Henry Field are silent on the subject of Rand's second catalogue.

${ }^{1}$ I am indebted to Mr. H. Howard Batten, the clerk to the Trustees of the Chelsea Physic Garden, for the loan of the block from which this plate was printed. 
itself to the demonstrators, Isaac Rand and Joseph Miller, in their writings, has been applied to the living plants themselves.

In 1736 Linné visited the garden, and cordial relations were established between the illustrious Swedish botanist and the personnel of the Chelsea Physic Garden. These relations were maintained through the medium of correspondence during succeeding years, with the result that the Linnean or "sexual" systern found among the members of the Chelsea Garden staff some of its earliest exponents in this country. William Hudson, an active member of the Garden Committee, who subsequently held the post of Demonstrator of Plants and Prefectus Horti from I 765 to I 771, was one of the earliest Linnean botanists in England, and he is even stated to have been the first author in this country who embraced the Linnean system. This statement, however, is perhaps not quite accurate, and it must not be forgotten that Benjamin Stillingfleet and James Lee, not to mention Philip Miller, had preceded Hudson in the publication of Linnean literature. In this connection the following estimate by Pulteney ${ }^{1}$ is probably not far from the truth:

"By all these preliminary advances, ${ }^{2}$ the learned were prepared to see the English botany modelled according to the rules of the Linncexn school. Dr. HILL seized the first opportunity of attempting it, in his Flora Britannica, 1760 ; but it was executed in a manner so unworthy of his abilities that his work can have no claim to the merit of having answered the occasion: and thus the credit of the atchievement fell to the lot of Mr. William HudSon, F.R.S., who, to an extensive knowledge of English plants, acquired by an attention to nature, had, by his residence in the British Museum, all the auxiliary resources that could favour his design: access particularly to the Herbaria of alnost all the assistants of RAY and Dilienius, ${ }^{3}$ mentioned in the Synopsis, ${ }^{4}$ gave him the opportunity of comparing the individual specimeus of

${ }^{1}$ Loc. cit., Vo1. II, pp. 351-352.

2 The "preliminary advances" mentioned by Pulteney comprise: References to the writings of Linné in Martyn's Virgil (I740), in Dillenius's Historia Muscorum (174I), in Blackstone's Specimen Botanicum (I746), and in the "Philosophical Transactions ;" (2) the arrangement of "all the plauts of RAY's Synopsis, according to the system of his master," by " a Swedish pupil of the Upsal school" (I754); (3) Browne's adoption of the Linnean system for classifying "his Jamaica plants" (I756); (4) Stillingfleet's "Translations of several tracts from the Amcnitates" (1759), and Lee's "Translation of the Elements of the Sexual System" (I760); and (5) Solander's arrival "into England on the Ist of July, I $760 . "$

${ }^{3}$ Dillenius was the first Sherardian Professor of Botany at Oxford.

${ }^{4}$ The first edition of Ray's Synopsis Stirpium Britannicarum was published in I69o. 'The third edition, by Dillenius, was issued in I724. 
that work with his own; and thus enabled hin1 to dispel a multitude of doubts and uncertainties, in which, otherwise, his application of the synonyma might have been involved."'

Even the venerable Philip Miller became converted to the Linnean doctrine, and the process of conversion is made apparent in the edition of 1759 of his dictionary, where the system of Linne is given a place. Miller, however, was at first reluctant to abandon the systems of Ray and Tournefort, to which he had been accustomed throughout his working life, but he was ultimately weaned from them completely, and we find him publishing, in his seventieth year, a "Short Introduction to the Knowledge of the Science of Botany, Explaining the Terms of Art Made Use of in the Linnæan System" (London, I 760). In the eighth edition of his dictionary (London, I768), which was the last published in his lifetime, the Linnean system only was recognized, but the alphabetical arrangement was still preserved. Once adopted, the " sexual" system of Linné swept all before it, and for a period of sixty years the Chelsea Physic Garden became one of its impregnable strongholds. William Curtis, the author of the Flora Londinensis and of the "Botanical Magazine," who was Demonstrator of Plants from I 773 to I777, was one of its most able exponents, as evidenced by his educational works : "Linnæus's System of Botany, so far as relates to his Classes and Orders of Plants" (London, I777), which was "drawn up for the use of his pupils," and "Lectures on Botany as delivered in the Botanic Garden at Lambeth," published posthumously in I805. Thomas Wheeler, his successor, was a staunch adherent of Linné to the last and a fierce antagonist of the "natural" system promulgated by Jussieu in I789. During his term of office the whole of the collections were arranged according to the "sexual" system, but the medicinal plants were still kept apart from the general collection.

The first attempt to introduce the natural system into the garden was made in $182 \mathrm{I}$, when the Demonstrator was requested to employ some time at each demonstration "in explaining to the Students the systems of Botany, both Sexual and Natural, as taught by Linnæus and Jussieu." When the scope of the lectures in the garden was extended in I 830, it was again specified that "the different systems of Botany, both natural and artificial, particularly those of Linnæus and Jussieu," should form a part of the course. The Catalogus Rationalis Plantarum Medicinalium, in horto Societatis Pharmacentice 
Londinensis, apud vicum Chelsea, cultarum, published by James Lowe Wheeler in 1830 , affords evidence that these instructions were carried into effect. The author in that work adopted the system of Linne in the main text, but this was supplemented by a Synopsis Plantarum Medicinalium, secundum Systema, D. Fussieu, dispositarum, and the class and order of Jussieu's Genera Plantanum, as well as Linné's Ordo Naturalis, were, moreover, mentioned under each genus in the portion classified according to the "sexual" system. The arrangement of the plants in the garden, however, seems to have undergone no change until the advent of Lindley, for Anderson, the gardener, was stubbornly attached to the Linnean creed, and refused to adopt any other. But when Lindley came upon the scene Anderson was forced to give way, and Lindley's system was gradually introduced. It is, nevertheless, interesting to note that Lindley himself realized that his system left much to be desired, and he ultimately almost abandoned it in his lectures. He saw clearly that all attempts to arrange a natural system in a consecutive series of natural orders must result in a series of compromises, and he therefore preferred to deal with the orders in natural groups which he termed Nixus or Tendencies, and Cohorts or Alliances. This attitude is curiously reflected in his Flora Medica, published in I 838 . In the preface to that work he says: "In the present state of systematical Botany no two writers upon classification can agree respecting the exact sequence in which the natural orders of plants should follow each other. By some the plan of Jussieu is adopted, by others that of De Candolle, and by many the systems of Endlicher, of the author of this work, of Von Martius, of Schultz, or even of Reichenbach, may be preferred. This can only be accounted for upon the supposition that the systems of all these authors are equally false." As a result, and in order " to enable the reader of this book to suit his own convenience in the arrangement of the matter, the work is so printed that the different natural orders may be cut asunder and re-arranged at the pleasure of the possessor."

The rearrangement of the plants in the garden was considerably delayed owing to the persistent hostility of Anderson to Lindley's wishes, but the Professor of Botany was equally insistent on having these complied with, so that pressure was brought to bear on Anderson with the result that a new arrangement of the medicinal plants was, so far as possible, completed in I 839 , and, in I 847 , the 
entire collections were rearranged by Fortune under Lindley's direction. The system of Decandolle was subsequently applied to a part of the collections, but we have no precise information as to when this took place. From the description given of the garden by Semple in I 878 we learn that both Decandolle's and Lindley's systems were at that date represented in the plantations of medicinal plants, the older and less important plantation being that arranged according to the system of Lindley. The portion to the south of the centre path which crosses the garden from the students' entrance in Swan Walk to the opposite side was occupied, as at present, by beds of hardy herbaceous plants, and the plants in this section of the garden were arranged in Decandollean orders, but the latter were not placed in sequence. Near the centre of the garden there was a span-roofed house divided into "stove" and greenhouse, and devoted to medicinal plants. No alteration in these arrangements appears to have been made until the garden changed hands, and Mr. Hales, the present Curator, informs me that, when he took over the collections, these, although much deteriorated, were substantially the same as in 1878 .

The description of the present collections will be dealt with in the next section, but before passing on to this we will consider very briefly some of the more noteworthy publications which have been mentioned in the preceding pages. The majority of these, as one would expect, were expressly designed for the use of students. The following, for instance, are all embraced in that category: Dale's Pharmacologia, Joseph Miller's Botanicum Officinale, the catalogues of Philip Miller and Isaac Rand, Philip Miller's "Short Introduction to the Knowledge of the Science of Botany," Curtis's "Linnæus's System of Botany" and his "Lectures on Botany," J. L. Wheeler's catalogue, and Lindley's Flora Medica. But Philip Miller's "Gardeners Dictionary," Hudson's Flora Anglica, and Curtis's Flora Londinensis take rank among the classics of English botany, while the last named author's "Botanical Magazine" and Lindley and Moore's "Treasury of Botany" are standard works of reference to this day. These by no means exhaust the list of publications issued by workers who were, at one time or the other, connected with the Chelsea Garden-the list of Lindley's published works, for instance, occupies twelve pages of the folio catalogue of the Library of the British Museum-but they are the most germane to our subject, and comprise all that we shall be able to consider here. 
Dale's Pharmacologia, or to give it its full title, Samuelis Dalei Pharmacologia, seu manuductio ad Materiam Mredicam: in qua Medicamenta Officinalia Simplicia, hoc est Mineralia, Vegetabilia, Animalia eorumque partes in Medicine Officinis usitata, in Methodum naturalem digesta succincte \& accurate describuntur, was first published in 1693 in a duodecimo volume, and went through several editions "both in this country and in foreign parts." The Tertia Editio (fourth British issue) appeared in quarto in 1737. Dale's work is written in Latin, but an English name is appended to each substance, and an Index Anglo-latinus in quo Nomina Anglica Latinis preponuntur, ordine alphabetico, is added at the end of the book "in gratian Tyronum;" in the Liber Secundus, "De Plantis Medicamentosis," Ray's system is used in toto. " The great merit of the Pharmacologia lies in the fact that it is free from the astrological and other absurdities which were rife in publications of a similar nature at that date, and it can therefore be looked upon as the first rational British text-book of materia medica that we possess. Ray, it is true, had paved the way in his writings by casting ridicule upon these old superstitions ${ }^{2}$ but

${ }^{1}$ Semple states, in his revision of Field's "Memoirs" (p. 65), that the system of Tournefort is adopted in the third edition of Dale's Phamacologia, but this statement is without foundation. Pulteney quite correctly says that "the arrangement of the work is that of Ray," and Dale himself, in the preface to his work, specifies his reasons for following this course in the following words:

"Præter Objectiones contra hunc 11ostrum Laborem, quæ supra in hac Præfatione refelluntur, restant $\&$ aliæ quædam, quibus obviam ire hoc in loco necesse duxi. . . . Deiudè, me stirpes ad Raianam Methodum, quæ à paucis intelligitur, disposuisse dicunt. Cum verò brevitati semper consului, satiùs duxi methodum talem instituere, qua singulas ejusdem herbæ partes simul tractare possem, neque eadem sæpius repeterem, ut necesse esset, si veterem Radicum, Corticum, Herbarum, Seminum, \&c. methodum, vel vires medicas secutus essem, uti ab aliis factum est. Hoc quidem caveri potuisset, si ordine Elementari omnia distribuissem; tunc verò Vegetabilia, aliaque congenera separata fuissent, qua legibus Physicis uniuntur; \& Lectori Philosophico, tanquam memoriæ ancilla, aptius hæ accommodantur leges: Et ut verun fatear, inter varias recentes Plantarum methodos intra paucos annos editas, Raianam, ut nature magis consentaneam, cæteris semper anteposui." Prafatio, p. vii.

2 Take, for instance, the following remarks by Ray in his Historia Plantarum, Tom. I, p. 46: "Signaturas præcipuè crepant Chymistæ. Chymicum autem dudum definivit Davisonus ut memini (quàm rectè ipse viderit) Animal credulum \&o mendax.

"Nos alibi Signaturas rejecimus, nec ullas notas naturæ consilio plantis impressas ut naturalium facultatum indices essent, demonstravinus, nec dum sententiam mutamus, ob rationes ibi adductas, quas hic repetemus."

[His reasons are then given, under seven heads.] 
the scope of Ray's works differed essentially from that of the Pharmacologia, for whereas Ray treats of plants in general, and only refers in a casual way to the properties of such plants as are used in medicine, Dale, in the Liber Secundus of his work deals particularly with medicinal plants and their products. The copious and accurate synonymy and the conciseness of Dale's Pharmacologia will best be demonstrated by quoting a portion of one of his monographs, and, for this purpose, we will select the first part of the monograph on gentian, relating to the plant which yields the gentian root of the pharmacopoias:

\section{De Gentiana.}

Note sunt, Folia nervosa, in caulibus ex adverso bina; flores calathoides, margine in lacinias aliquot totidem folia imitantes plerumque diviso; sapor amarus, Raii Synop. p. Io2.

A. I. Gentiana, Offic. Chab. 503. Gentiana major, Ger. 351. Emac. 432. Raii. Hist. i. 716. Gentiana major lutea, C. B. Pin. 187. Tourn. Inst. 8o. Elem. Bot. 96. Boerh. Ind. A. 204. Hist. Oxon. iii. 484. Park. Parad. 350. Gentiana vulgaris major Ellebori albi folio, $J$. $B$. iii. 520. (jonftan. In hortis curiosorum. Junio floret. Usu. Radix oblonga, crassa, foris fusca, intus ex flavo rufescens, saporis intensè amari. Vires. Alexipharmaca est; aperit, attenuat. Usus præcipui in peste, aliisque venenatis affectibus; in obstructione hepatis, lienis, \&c. Schrod.

The reader has only to compare this abstract with the interminable descriptions of Parkinson ${ }^{1}$ or the verbiage of William Coles io appreciate the great advance that it represents.

Just as Dale's Pharmacologia may be looked upon as our first rational text-book of Materia Medica, so may Joseph Miller's "Botanicum Officinale; or a Compendious Herbal giving An Account of all such Plants as are now used in the Practice of Physick. With their Descriptions and Virtues" (London, I722), be regarded as the first text-book of vegetable Materia Medica, worthy of the name, in the English language. Although Joseph Miller's Botanicum Officinale is a smaller work than Dale's, it is better adapted to the needs of the beginner, for it is written in English, and in place of Dale's copious synonymy, which is more particularly of value to the advanced student, the author has given longer descriptions of the plants, which he hopes, "will not be thought too particular, or unnecessary, since they are written with a Design to render this Treatise

'The virtues of Gentian as described by Parkinson would fill over two pages of the present work. 
as informing as possible; and in Order to it," he has "not only consulted Authors of the greatest Name in Botany," but has "had Recourse to most of the Simples themselves in their natural Productions. All. the Materials are disposed in alphabctical Order, and under the same Names they bear in the Catalogue of Simples in the last Edition of the College Dispensatory, together with those given them by Caspar Bauhin, Gerard, and Parkinson, Authors easiest to be met with." The following abstract from the Botanicum Officinale will show more clearly than any description would do, the difference between the two works:-

Gentiana, Gentian, Off. — major, great Felwort, Ger. —-major lutea, great Gentian, or Felwort, C. B. Park.

The Root of the Great Gentian is large, thick, and woody, pretty much divided, of a yellow brown Colour, and a very Bitter Taste; the lower Leaves are pretty long and broad, somewhat roundish, but pointed at the Ends, stiff, and pretty much of the Shape of the Leaves of white Hellebore [compare Plates XIX and $\left.\mathrm{XX},{ }^{1}\right]$, but of a yellow green Colour, with five large Veins on the Back of each. The Stalk arises to be a Yard or more high, having two smaller and shorter Leaves growing opposite at each Joint, which are at some Distance. Among these, on the upper Part of the Stalk, the Flowers grow verticillatim, or are set round it; they are monopetalous, or of one Leaf divided almost to the Bottom, into five Segments, 1aid open like a Star, with a green Umbo in the Middle, beset with yellow Stamina and Apices. The Seed is small and brown, growing in longish round Seed-Vessels. It grows wild in the Alps, and in several Mountainous Parts of Germany; flowering in July. The Roots are used.

The virtues are described by Joseph Miller in inverted commas, and, according to Pulteney, ${ }^{2}$ they were taken from [one of the earlier editions of ] the Pharmacologia, but they are inferior to those of the third edition of that work. In the present instance, for example, "Gentian Roots" are described as " hot and dry," but this Aristotelian taint is the only relic left of medieval superstition, and the remainder of the description, which seems to have been originally condensed from Parkinson, is similar to that given by Dale.

The monograph ends with the statement that the "Officinal Prep. arations are a Compound Water and an Extract" - information obviously useful to the Apothecary's apprentice.

We have dealt at some length with these two books, as they are of especial interest to the pharmacist, but the remainder of the works on our list must be considered as briefly as possible.

1 The plant represented on Plate $\mathrm{XX}$ is Veratrum viride, and not Veratrum album, but it will serve just as well.

2 Loc. cit., Vo1. II, p. IO3. 
There is little to add to what has already been said on the subject of Philip Miller's and Isaac Rand's catalogues, save that Rand's Index of I739 is written entirely in Latin, that the arrangement is alphabetical, and that "Ray and Tournefort are the principal authorities referred to."

The scope of J. L. Wheeler's catalogue will be made apparent by the foilowing abstract:-

\section{CLASSIS $V$.}

\section{ORDO II.}

PENTANDRIA. DIGYNIA.

* Flores Monopetali inferi.

GENTIANA. Willd. Spec. Plant. i. I33I. Persoon Syn. i. 284.

ORDO NAT. ROTACE无. Linn.

CLASSIS VIII. ORDO XIII. GENTIANAE. Capsula simplex unilocularis. Juss.

CHAR. GEN. Corolla monopetala. Capsula bivalvis, unilocularis. Receptaculis duobus, longitudinalibus.

* Corollis 5-9 fidis subcampanulatis.

47. GENTIANA LUTEA.

CHAR. SPEC. Foliis latis ovatis nervosis, corollis subquinquefidis rotatis verticillatis. Calycibus spathaceis.

ANGLICE, Gentian.

LOCUS. In alpibus et subalpinis pratis. Perennis.

VIS. Amarissima. Tonica præstans, parum nauseosa.

USUS. In Dyspepsiâ.

COMP. Ext. Gentianæ. Lond. Edin. Eblan. ${ }^{1}$ Inf. Gent. Comp. Lond. Edin. Eblan. Tinct. Gent. Comp. Lond. Edin. Eblan. Vinum Gent. Comp. Edin.

Of Philip Miller's "Short Introduction" to Botany nothing further need be said, but a few words must be spared for Curtis's "Linnæus's System of Botany" and his "Lectures on Botany." Both of these were published after the author had severed his connection with the Chelsea Physic Garden in order to found a school of his own in his garden at Lambeth, and they are chiefly remarkable for the beautifully executed and accurate engravings which they contain. These are printed from copper plates, and are designed to illustrate the terms used in Botany and the divisions of the Linnean System, by means of representations of the living plants.

1 These refer to the preparations official in the Pharmacopœias of London, Edinburgh, and Dublin respectively, now merged into one : the British Pharmacopœia. 
Lindley's "Flora Medica; a botanical account of all the more important Plants used in Medicine, in different parts of the World" (London, 1838 ) is a modern text-book in every sense of the word, and it could very advantageously do duty at the present day, with but little alteration. The generic and specific characters are very fully, albeit concisely, given, and the medicinal uses of the plants are admirably summarized. Indeed, in looking through the book one is struck by the fact that the additions which have been made since then to our knowledge of the subject are relatively unimportant. We have, it is true, located the active constituents of many plants, but Lindley does not deal with plant analysis, and the therapeutical properties of the drugs which we use were known in I 838 , although their active principles may not have been isolated nor the mechanism of their action on living tissues determined. The Flora Medica, however, did not appeal to the class for which it was intended. This was probably due to the fact that there was too much botany in it for the average medical student, while, on the other hand, the botanist capable of appreciating Lindley's work would naturally prefer to consult more comprehensive works on Systematic Botany. But Lindley's labors were not entirely in vain, for the information which he had so laboriously compiled on the medicinal uses of plants was utilized by the medical botanists who contributed to the "Treasury of Botany."

"The Gardeners Dictionary" by Philip Miller was first published in I724. The first edition in folio appeared in I73I, and the last edition, in four folio half-volumes, was issued in I 807 under the editorship of Thomas Martyn, the then Regius Professor of Botany in the University of Cambridge. Martyn's preface contains a detailed account of all the various editions of Miller's magmum opus, and to this we must refer the reader who is interested in the subject. For nearly a century the "Gardeners Dictionary" was the recognized authority on gardening in this country, and we find Linné saying of it: "Non erit Lexicon Hortulanonm, sed etiam Botanicorum." Miller's work is, therefore, of considerable historical interest at the present day, inasmuch as its several editions reflect the progress of gardening in this country during the period in which they were published. It is of interest to record that in the eighth edition, published in I768, Miller suggests that certain useful plants "as namely the Safflower, Indigo, and several other sorts used in dyeing, 
none of which will thrive in this country to advantage, with many medicinal drugs" should be cultivated in the West Indian Possessions. From the account which has already been given of the work of Kew Gardens it will have been noticed that the suggestion put forward by Philip Miller in I 768 was partly acted upon subsequently (see Chapter II, on "Kew Gardens," pp. 37-38). In I732 Philip Miller published his "Gardeners Kalendar." This little book, which may be looked upon as a supplement to the "Gardeners Dictionary," went through fifteen editions in the author's lifetime, and its principal interest to us lies in the fact that "A List of the Medicinal Plants which may be gather'd in each Month for Use" is added to the ninth edition-a circumstance which would lead us to suppose that the apothecary, in Miller's day, cultivated his own drugs, or, at all events, gathered those which were indigenous.

Hudson's Flora Anglica has already been referred to at some length, and it is only necessary to add that it was for many years the standard guide to the flora of this country. The first edition was published in 1768 in one volume, and the second in 5778 , in two volumes.

William Curtis's Flora Londinensis and "The Botanical Magazine" may be taken together. The beauty and accuracy of the plates, which are reproduced in every case from the living plants, constitute the dominant feature of these two works, as of all Curtis's publications. The Flora Londinensis was commenced in 1777 , but only six fasciculi were issued, as the subscriptions did not cover expenses. Each fasciculus contains the plates and descriptions of 72 plants growing "wild in the Environs of London," printed on large folio sheets. In the "English Botany" by Sowerby and Smith, which appeared subsequently, the task which Curtis had begun in his Flora Londinensis was, to some extent, completed, and even extended, but the plates of the former work are not to be compared with those of Curtis's six fasciculi. The first number of "The Botanical Magazine; or Flower-Garden Displayed" was issued in 1787 , and the plan of the work, which has been faithfully adhered to in its essentials ever since, is outlined by Curtis in his preface as foliows:-

"The present periodical publication owes its commencement to the repeated solicitations of several Ladies and Gentlemen, Subscribers to the Author's BOTANIC GARDEN, who were frequently lamenting the want of a work, which might enable them, not only to acquire a systematic knowledge of the Foreign 
Plants growing in their gardens, but which might at the same time afford them the best information respecting their culture-in fact, a work, in which Botany and Gardening (so far as relates to the culture of ornamental Plants) or the labour of LINN EUS and MILLER, might happily be combined.

"In compliance with their wishes, he has endeavoured to present them with the united information of both authors, and to illustrate each by a set of new figures drawn always from the living plant, and coloured as near to nature, as the imperfection of colouring will admit.

"He does not mean, however, to confine himself solely to the Plants contained in the highly esteemed works of those luminaries of Botany and Gardening, but shall occasionally introduce new ones, as they may flower in his own garden, or those of the curious in any part of Great-Britain."

After Curtis's death the "Botanical Magazine" was continued by John Sims, who was succeeded by Sir William Hooker, to be followed in turn by Sir Joseph Hooker, and by the present editor, Sir William Dyer. The value of the "Botanical Magazine" to the pharmacist is evidenced by the fact that, in the last edition of the British Pharmacopoia, he is referred to that magazine for plates of the following plants: Aloe Chinensis, Baker (Bot. Mag., plate 630I); Aloe Perryi, Baker (Bot. Mag., plate 6596); Erythroxylon Coca, Lam. (Bot. Mag., plate 7334); Hamamelis Virginiana, L. (Bot. Mag., plate 6684); Illicium verum, Hook. f. (Bot. Mag., plate 7005); Pilocarpus Jaborandi, Holmes (Bot. Mag., plate 7483); Quillaja saponaria, Molina (Bot. Mag., plate 7568); and Smilax omata, Hook. f. (Bot. Mag., tab. 7054).

"The Treasury of Botany," edited by Lindley \& Moore, is last on our list, but not least. It would be a work of supererogation to describe a book which is so well known to every economic botanist, but it is no exaggeration to say that there is no other work on the same subject which contains so much information compressed into so small a space.

With the "Treasury of Botany" we may fitly close our account of the work accomplished in the Chelsea Physic Garden under the ægis of the Society of Apothecaries. On contemplating these splendid achievements we cannot but experience a feeling of regret that the institution which had been fostered by the Apothecaries for so long a period, at such great sacrifice, should eventually have fallen into decay. It was, however, in the nature of things that this should have resulted, for botanical studies have now been practically divorced from the medical curriculum, and the duties of the Apothecary have been relegated to his successor, the pharmacist. 



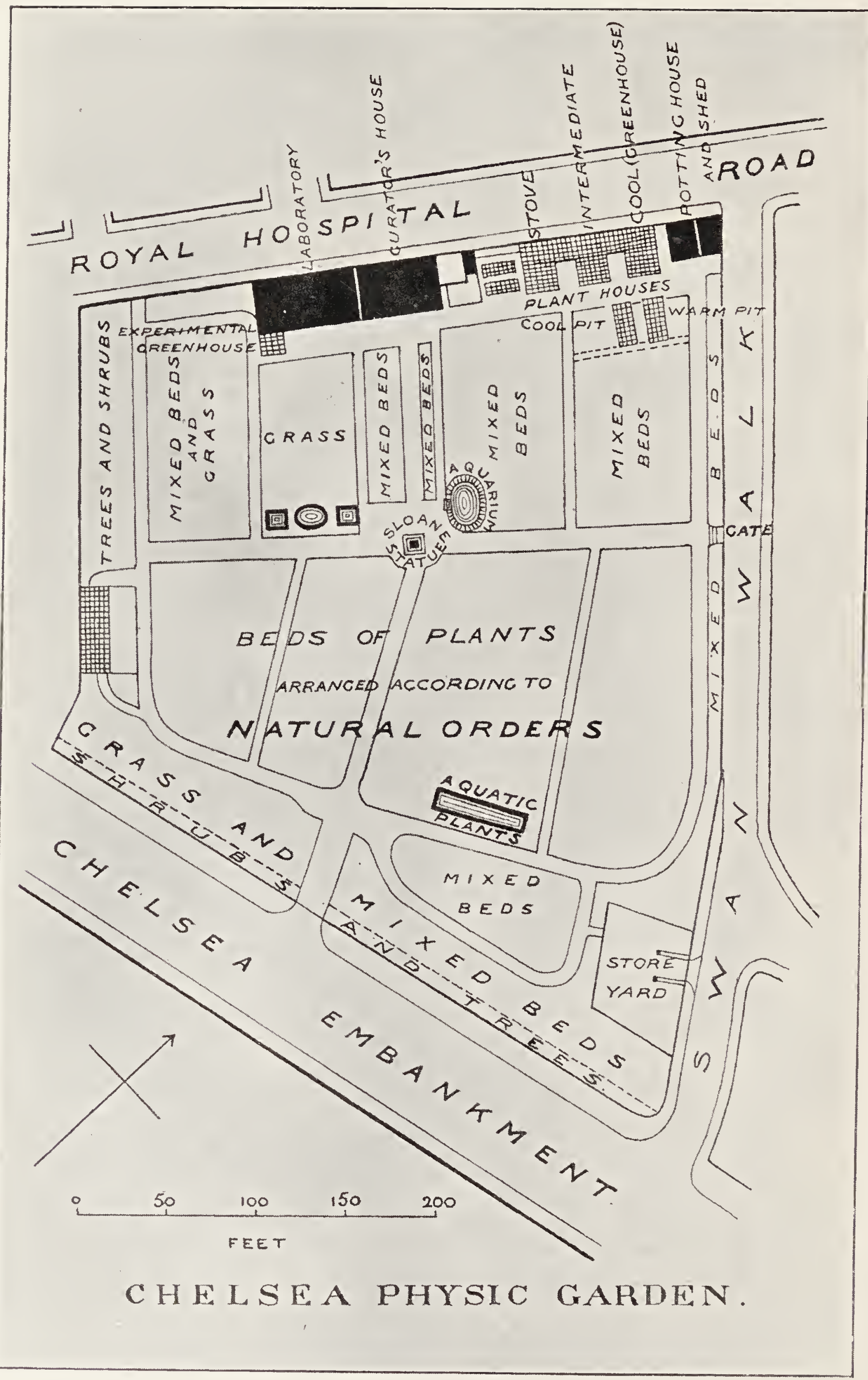


THE CHELSEA PHYSIC GARDEN UNDER THE PRESENT ADMINISTRATION.

In I893 the Apothecaries "applied to the Charity Commissioners for a Scheme which might provide for their relinquishment of the trust." On this occasion they were more successful than they had been in their previous negotiations with the Royal Society and the Royal College of Physicians, for, as a result of their application, a Treasury Committee, consisting of Sir Henry Longley, Sir W. T. Thiselton.Dyer, and Mr. Spring Rice, was appointed to inquire into the matter, "with reference to a suggestion that the garden should be supported by Imperial funds, with especial reference to its use by the students of the Royal College of Science at South Kensington." The principal reason advanced by the Society of Apothecaries for abandoning the garden was that the latter was no longer suitable for the purposes of a botanic garden, owing to the deleterious effects of London smoke and the impoverished condition of the soil. The above-mentioned Treasury Committee, however, "satisfied themselves that the garden was still well fitted for botanical purposes, and that its advantages were likely to be highly appreciated by the students of the Royal College of Science and of the various Polytechnics." In view of this favorable report the Charity Commissioners approached the Trustees of the London Parochial Charities to ascertain whether the latter would be willing to provide, or to assist in providing, funds for the maintenance of the garden. The Trustees, in response to these advances, agreed to contribute $£ 800$ per annum towards the upkeep of the garden, while the Treasury expressed its willingness to provide a yearly sum of $£ 150$ for the same purpose. The Society of Apothecaries accordingly surrendered the garden on February 2 I, I 899, and the Charity Commissioners then established a Scheme by which "the Trustees of the London Parochial Charities were created the Trustees of the Garden," while its administration was entrusted to a committee of management constituted as follows:

Nine members appointed by the Trustees.

One member appointed by each of the following: The Treasury, the Lord President of the Council, the Technical Education Board of the London County Council, the Royal Society, the Pharmaceutical Society of Great Britain, and the Senate of the University of London. 
One member appointed in turn by the Society of Apothecaries and the Royal College of Physicians.

These members were appointed for four or five years, and, with the exception of the last named, are eligible for reappointment at the expiration of their term of office.

To these sixteen members the representative of Sir Hans Sloane was added as ex-officio member of the committee.

In July, I 899, this committee appointed Mr. William Hales as Curator of the Garden, and, on the recommendation of Prof. J. Bretland Farmer, F.R.S., the Professor of Botany in the Royal College of Science, the Trustees were requested by the committee "to expend a sum of $£ 4,230$ in new buildings, and repairs and alterations to the existing buildings." The project was subsequently modified, owing to the fact that a sum of $£ 2,000$ was realized by the sale " of a strip of frontage to Royal Hospital Road (then known as Queen's Road) to the vestry of Chelsea." This necessitated the pulling down of the Curator's house and other buildings, so that, on the application of the Trustees, an expenditure of $£ 6,000$ was ultimately authorized by the Charity Commissioners. The balance $\left(£_{4}, \mathrm{COO}\right)$, was advanced by the Trustees, "to be repaid in thirty years out of the income of the garden," which "consists of the $£ 800$ paid by the Trustees, the $£ 150$ paid through the Board of Education, and an annual sum of $£$ IO paid by the University of London in consideration of the many and exceptional specimens supplied for examinations."

The buildings were completed in I902, and on July $25^{\text {th }}$ of that year the garden was formally reopened by the Earl of Cadogan, who is "the ex-officio member of the committee, and a lineal descendant of Sir Hans Sloane."

With this brief account of the reorganization of the garden we will proceed at once to the description of the garden under the present administration. We shall consider, first of all, the collections growing out of doors, then the plant houses and other buildings, and, finally, the work that is being done in the garden.

The Collections growing out of doors.-When the garden was taken over by the present Trustees it was found to be in a very dilapidated condition, but under the energetic curatorship of $\mathrm{Mr}$. William Hales it has been transformed into the most efficient educational botanic garden in the metropolis. During the years 1900 

I90I, and I902 a liberal supply of turf, loam, manure and gravel was utilized in renovating the garden, and "instruments, tools, pots, mowing-machines, watering-hose, and the many other necessary articles essential to a well-equipped garden" were adequately provided. The stocking of the beds was then proceeded with, the arrangement adopted being shown on Plate XXVI. Plants and seeds were obtained from the various British botanic gardens, and the old plants were correctly renamed so far as possible. Special pains have been taken in labeling the specimens, and old mistakes are nearly all rectified. In rearranging the beds, the special collections of medicinal plants were suppressed and the various patterns of beds which had been in use were reduced to a common type of narrow parallel ones (see Plate XXX), the plants being thereby rendered more accessible. The main portion of the herbaceous collections is located in the southern half of the garden (see Plate XXVI), where the plants are arranged in regular sequence of natural orders according to Bentham and Hooker's Genera Plantarum. Over one hundred natural orders are represented, in many cases by medicinal plants. The plants in the "mixed beds" consist mainly of such duplicates as are most frequently needed for teaching purposes. The trees and shrubs are not numerous, but, in addition to those indicated on Plate XXVI, there are a few groups and isolated specimens scattered about the garden (see Plates XXIV and XXX.) The following list includes most of the plants of interest in pharmacy that were grown out of doors in the Chelsea Garden in 1905 :-

Achillea Millefolium, L.; Aconitum ferox, Wall., A. Fischeri, Reichb., and A. Napellus, L. ; Athusa Cynapium, L., fool's parsley; Agrimonia Eupatoria, L., the "Aigremoine" of the French Codex; Althaa officinalis, L.; Anacyclus Pyrethrum, L.; Anthemis Cotula, L., and A.nobilis, L.; Apocynum cannabinum, L., Canadian hemp, the root of which is the "Apocynum" of the U.S.P.; Archangelica officinalis, L.; Arctium Lappa, L., burdock, whose root is official in the U.S.P., under the name of "Lappa"; Arctostaphylos Uvaursi, Spreng.; Arnica montana, L.; Artemisia Absinthium, L.; Arum maculatum, L., the "Arum," "Gouet," or "Pied-de-veau" of the Codex, with a starchy rhizome from which "Portland Arrowroot" was formerly obtained; Asarum Canadense, L., wild ginger or Canadian snakeroot, the rhizome of which contains an aromatic essential oil; Asparagus officinalis, L., now little used in medicine, though still represented in the Codex by the rhizome and roots, and by the young shoots (Turnons d'Asperge); Atropa Belladonna, L.; Avena satıva, L., whose fruits, freed from their glumes, constitute the "Gruau d'Avoine" of the Codex; Borago officinalis, L., represented in the Codex by the leaves, from which a succus and an extract are prepared, and by the 
flowers, of which an infusion is made; Brassica alba, Hook. f., white mustard, $B$. Napus, L., which yields rapeseed oil, and $B$. nigra, Koch, black mustard; Bryonia dioica, Jacq., one of the two species of Bryonia from which the Bryony Root of the homœopaths is obtained; Calamintha officinalis, Moench, the "Calament" of the Codex; Calendula officinalis, I.; Cannabis sativa, I., the Indian variety of which yields the "Cannabis Indica" of the pharmacopoias; Canum Carvi, I., and C. Petroselinum, Benth et Hook. f.; Centaurea (yanus, L., whose flower-heads constitute the "Bluet" of the Codex; Chelidonium mojus, L.; Chenopodium anthelminticum, L., the "Ansérine vermifuge" of the Codex, which yields a volatile oil official in the U.S.F.; Chrysanthemum Parthenium, Bernh., and C. roseum, Weber, the latter of which yields Persian insect flowers; Cichorium Intybus, I. ; Cimicifuga racemosa, I. ; Cnicus benedictus, I.; Cochlearia Armoracia, L., the horseradish, and C. officinalis, L., or common scurvy grass, which, as its name indicates, was formerly much used as a remedy for scurvy, and is still official in the Codex, entering into the preparation of a compound spirit of horseradish and of a confection; Colutea arborescens, L., bladder senna, the leaflets of which were stated by Pereira to have been used on the Continent for the purpose of adulterating senua; Conium maculatum, L.; Coriandrum sativum, L.; Cucurbita Pepo, L., which yields pumpkin seed, used as a tænifuge; Cynoglossum officinale, L., whose root appears to have been expressly introduced into the Codex to mask the name of a compound opium pill, known as "Pilule de Cynoglosse" (cf. the Compound Pill of Soap of the British Pharmacopœia); Cytisus scoparius, L.; Daphne Mezereum, L.; Datura Stramonium, L., and the closely related $D$. Tatula, L.; Daucus Carota, I., Dictamnus albus, L., the "Fraxinelle" or "Dictame blanc" of the Codex; Digitalis purpurea, L. ; Ecballium Elaterium, A. Rich.; Echium vulgare, I., the flowers of which are generally known in French conmerce as "Fleurs de Buglosse," although Anchusa officinalis, L., is the "Buglosse" of the Codex; Eryngium campestre, I., the "Chardon Roland" or "Panicaut" of the Codex; Fragaria vesca, the strawberry, whose rhizome and fruit are both official in the Codex; Fraxinus Ornus, L.; Galium Mollugo, L., the "Cail.e. lait blanc" of the Codex; Geranium maculatum, L., the rhizome of which constitutes the "Geranium" of the U.S.P.; Geum urbanum, L., whose astringent roots form the "Souches de Benoite" of the Codex; Glycyrrhiza glabra, I.; Gratiola officinalis, L., the "Gratiole" of the Codex; Hordeum vulgare, I., whose fruits are used in the preparation of nialt extract and for making barley water; Humulus Lupulus, L. ; Hyoscyamus niger, L. ; Hypericum perforatum, I., whose flowering tops are still retained in the Codex: Hyssopus officinalis, L., the " "Hysope" of the Codex; Inula Helenium, L.; Iris Florentina, I. ; Isatis tinctoria, L., the woad, which yields a blue dye that was extensively used before the introduction of indigo; Laums nobilis, L., Lavandula vera, D C.; Levisticum officinale, Koch; Linum usitatissi. mum, L.; Malva sylvestris, L., the leaves and flowers of which are official in the Codex; Marrubium vulgare, I., the "Marrube blanc" of the Codex, also official in the U.S.P.; Melilotus officinalis, Lam.; Melissa officinalis, L.; Mentha Piperita, L.; Morus nigra, L., the mulberry tree, whose fruits enter into the preparation of a syrup in the Codex; Nicotiana Tabacum, I.; Nigella Damascena, L., Enanthe crocata, L., a rank poison which has been mistaken 



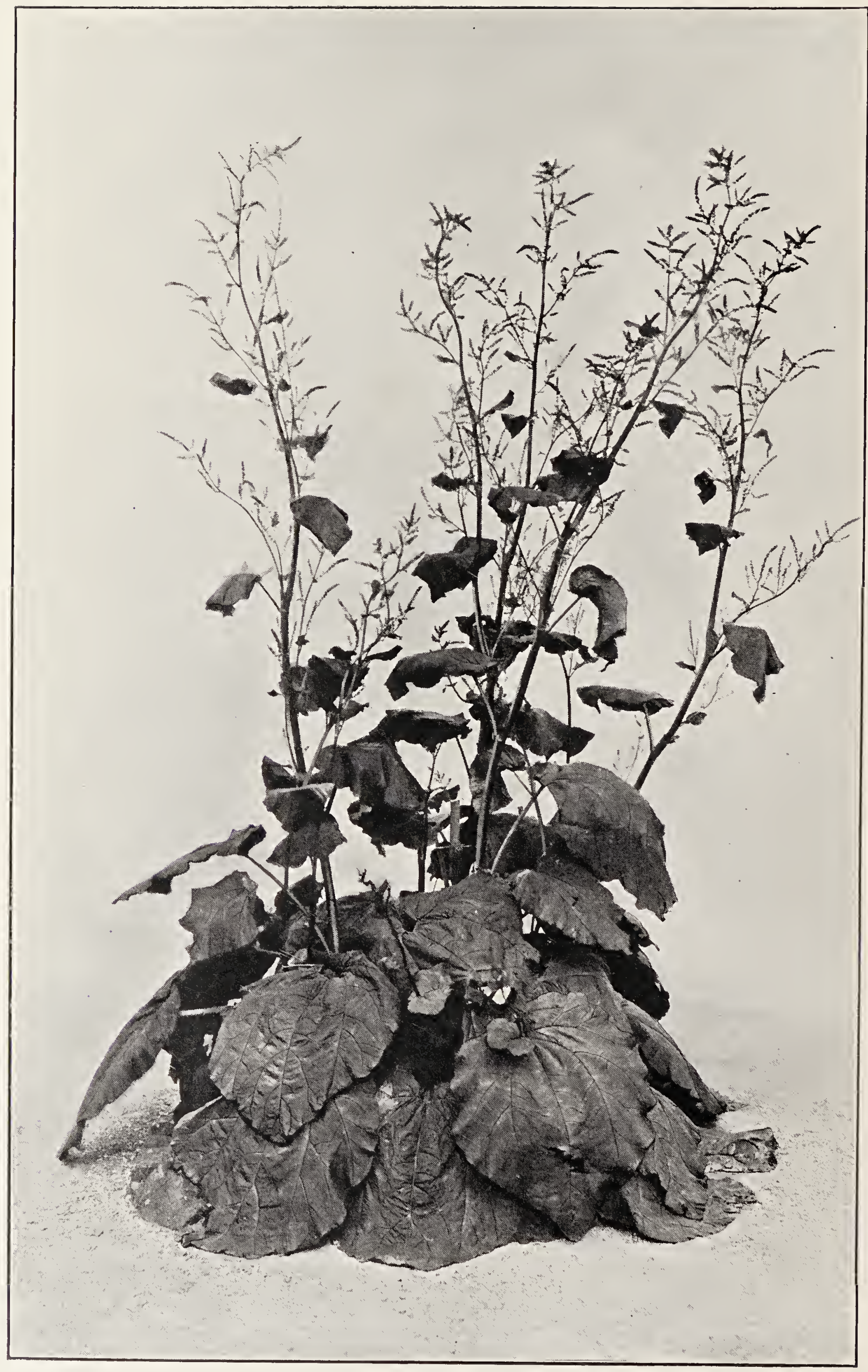

RHEUM OFFICINALE, BAILL. [?]. 


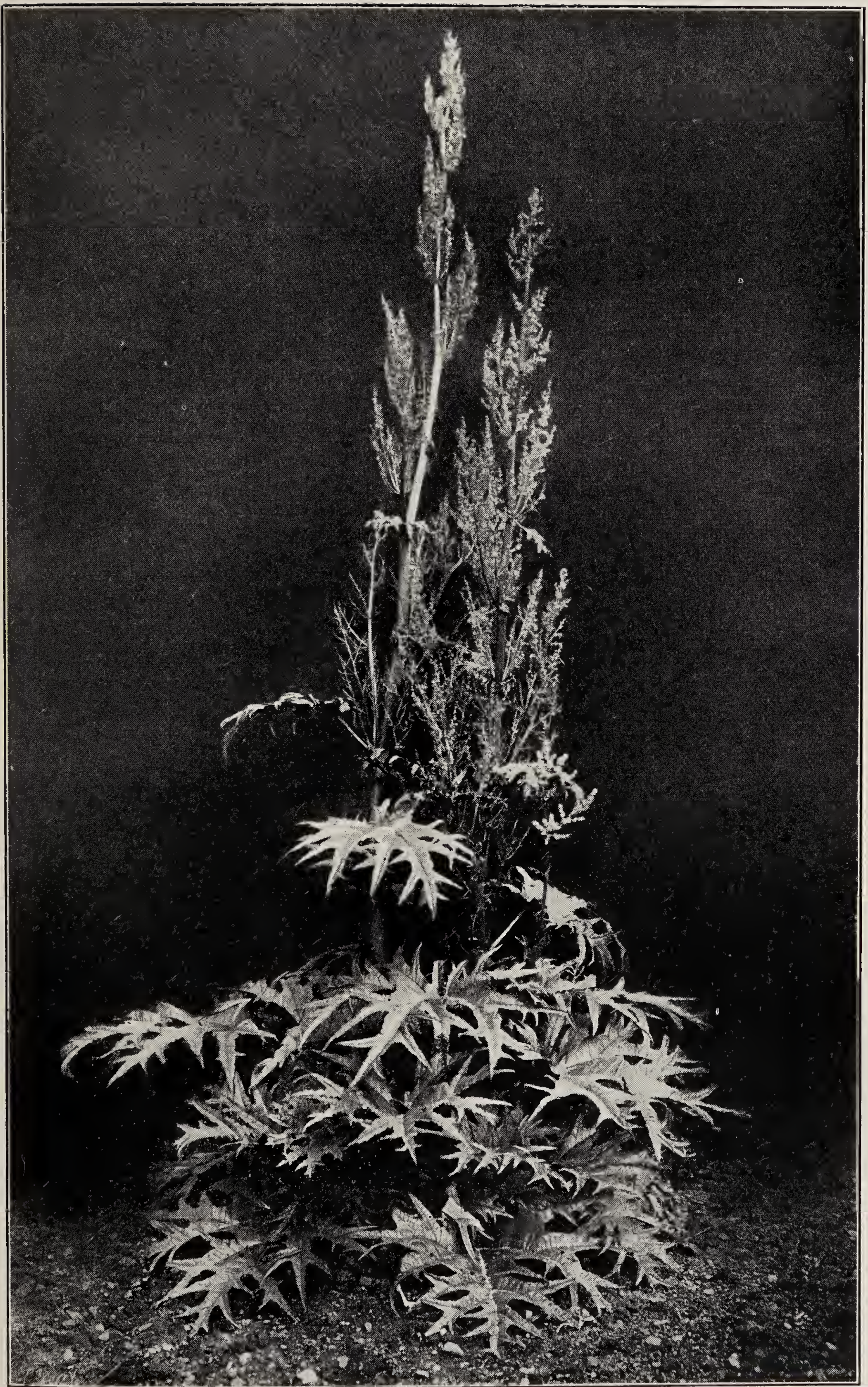

RHEUM PALMATUM, L.,

Growing in the Chelsea Physic Garden. 

for celery and other Umbelliferae; Ononis spinosa, L., which yields the "Hauhechelwurzel" of the German Arzneibuch; Opoponax Chironium, Koch; Origanum vulgare, L., the "Origan vulgaire" of the Codex, and $O$. Majorana, I., the "Marjolaine" of the same work; Papaver Rhoxs, L., and P. somniferum, I.; Peucedanum Ostruthium, Koch ; Phytolacca decandra, L.; Pimpinella magna, I., the root of which is official in the Arzneibuch under the name of "Radix Pimpinelle", or "Bibernellwurzel," Plantago major, I., P. media, I., and P. lanceolata, I., all included under the term "Plantain" in the Codex, and P. Psyllium, L., whose seeds are also official in that work, a mucilage being prepared from them which is similar to the "Decoctum Ispaghulce" of the Indian and Colonial Addendum of the B.P., but the drug used in this case consists of the seeds of Plantago ovata, Forsk; Podophyllum peltatum, I., the source of the Podophyllum rhizome of the pharmacopœias; Polygonatum officinale, All.; Polygonum Bistorta, L.; Potentilla Tormentilla, Neck., the "Tormentille" of the Codex; Prunella vulgaris, L., self-heal; Prumus Amygdalus, var. dulcis, Stokes, which yields sweet almonds, and $P$. serotina, Ehrh.; Pulmonaria officinalis, I.; Pyrus intermedia, Ehrh., with acid fruits similar to those of the mountain ash; Rhamnus Frangula, L.; Rheum officinale, Baill., ${ }^{1}$ R. palmatum, I., and the variety tanghuticum; Ribes nigrum, L., the "Cassis" of the Codex; Ricinus communis, L.; Rosa canina, I. ; Rosmarinus officinalis, I.; Rubia tinctorum, L.; Rumex acetosa, I., the "Oseille commune" of the Codex, and R. Patientia, L., which, together with other species of Rumex, yields the "Racine de Patience" of the same work; Ruta graveolens; I. ; Salvia officinalis, I. , of which the flowering plant or leaves are official in the Codex, Arzneibuch, and U.S.P.; Sambucus Ebulus, I., the source of the "Baies d'Hièble" of the Codex, and S. nigra, L. ; Saponaria officinalis, I., whose leaves, stem, and root are official in the Codex; Scopola Carniolica, Jacq.; Scutellaria lateriflora, I., or skullcap, the "Scutellaria" of the U.S.P.; Secale cereale, L., on which grows the ergot of the pharmacopœias; Solanum Dulcamara, L., and S. nigrum, L. ; Spircea Ulmaria, L., the "Ulmaire" or "Reine-des-près" of the Codex; Stachys Betonica, Benth., the "Wood Betony" of herbalists, still retained in the Codex; Tanacetum vulgare, L.; Taraxacum officinale, Weber; Teucrium Chamodrys, L., the "Germandrée Chamadrys" or "Petit chêne" of the Codex; Tilia platyphyllos, Scop.; Trigonella Fenum-gracum, L.; Triticum vulgare, Vill., wheat; Valeriana officinalis, I.; Veratrum album, I., and $V$. viride, Soland.; Verbascum Thapsus, L.; Verbena officinalis, I., a worthless drug formerly of great repute, and still official in the Codex; Vincetoxicum officinale, Moench, the "Asclépiade" or "Dompte-venin" of the Codex; Viola tricolor, L., the "Pensée sauvage" of the Codex, and the "Stiefmütterchen" of the Arzneibuch; and Zea Mays, L., whose styles and stigmas constitute cornsilk, or the "Zea" of the U.S.P.

The Plant Houses.-Chief among these is the range of planthouses completed in 1902, and situated on the north side of the

${ }^{1}$ The fine specimen represented on Plate XXVIII is a hybrid between $R$. officinale and $R$. Emodi, but there is also some typical $R$. officinale in the collections. 
garden (See Plates XXVI and XXX). This type of range is the one that has been found most suitable for educational purposes, and therefore it has also been adopted in the botanic gardens at Cambridge and Oxford. There are three houses in this range, a stove, heated to $65^{\circ}-70^{\circ} \mathrm{F}$, an intermediate house, heated to $55^{\circ}-60^{\circ}$ $\mathrm{F}$, and a cool house maintained at about $45^{\circ}-50^{\circ} \mathrm{F}$., and these all open into a lean-to corridor heated to the intermediate temperature, so that access from one house to the other is made possible without the necessity of subjecting the plants to such great changes of temperature as if the houses only communicated with the outside air. Various kinds of plants are represented, and those of economic interest are distributed among the others. The medicinal plants are not numerous, but the following may be mentioned:-

In the Stove.-Ilex Paraguayensis, Lamb.; Myroxylon toluiferum, H.B.K., Zingiber officinale, Rosc.

In the Intermediate House.-Adhatoda Vasica, Nees, whose fresh and dried leaves constitute the "Adhatoda" of the Indian and Colonial Addendum to the B.P.; Anamirta Cocculus, W. \& A.; Bixa Orellana, I.; Canella alba, Murr.; Coffea Arabica, I.; Dracona Draco, L.; Peumus Boldus, Molina; Phonix dactylifera, I.; Picrena excelsa, Lind1.

In the Greenhouse.-Agathis australis, Salisb., (Dammara australis, Lamb.), the Kaurie Pine, from which is ottained a resin similar to copal ; Cinnamomum Camphora, Nees; Drimys Winteri, Forst.; Eucalyptus globulus, Labill.; Melaleuca sp.; Rhamnus Californicus, Eschsch., and R. Purshianus, DC.

In the Corridor.-Aloe sp., Ceratonia Siliqua, L.; Citrus Aurantium, L, C. medica, L., and C.medica, I., var. Limonum; Dracena Draco, L.; Ficus elastica, Roxb.; Picrana excelsa, Lind1.; and Pilocarpus pennatifolius, Lem.

Facing the range of plant-houses are two pits (see Plates XXVI and XXX), one a warm pit, the other a cool pit. The former con. tains a collection of cryptogams, such as Selaginellas, Lycopodiums, etc., and other specimens used in teaching; whereas in the cool pit one side is occupied by succulents, and the other is used for forcing purposes. A new propagating house is being added in igo6.

The lean-to-house on the west of the garden is the only one of the old plant-houses remaining. It was thoroughly repaired after the transfer of the garden, and is chiefly used as a fern house. Among its noteworthy features the examples of Wardian cases which it contains may be mentioned, as also a fine collection of liverworts and some luxuriant specimens of the male fern (Aspidium Filix-mas, Swartz). 


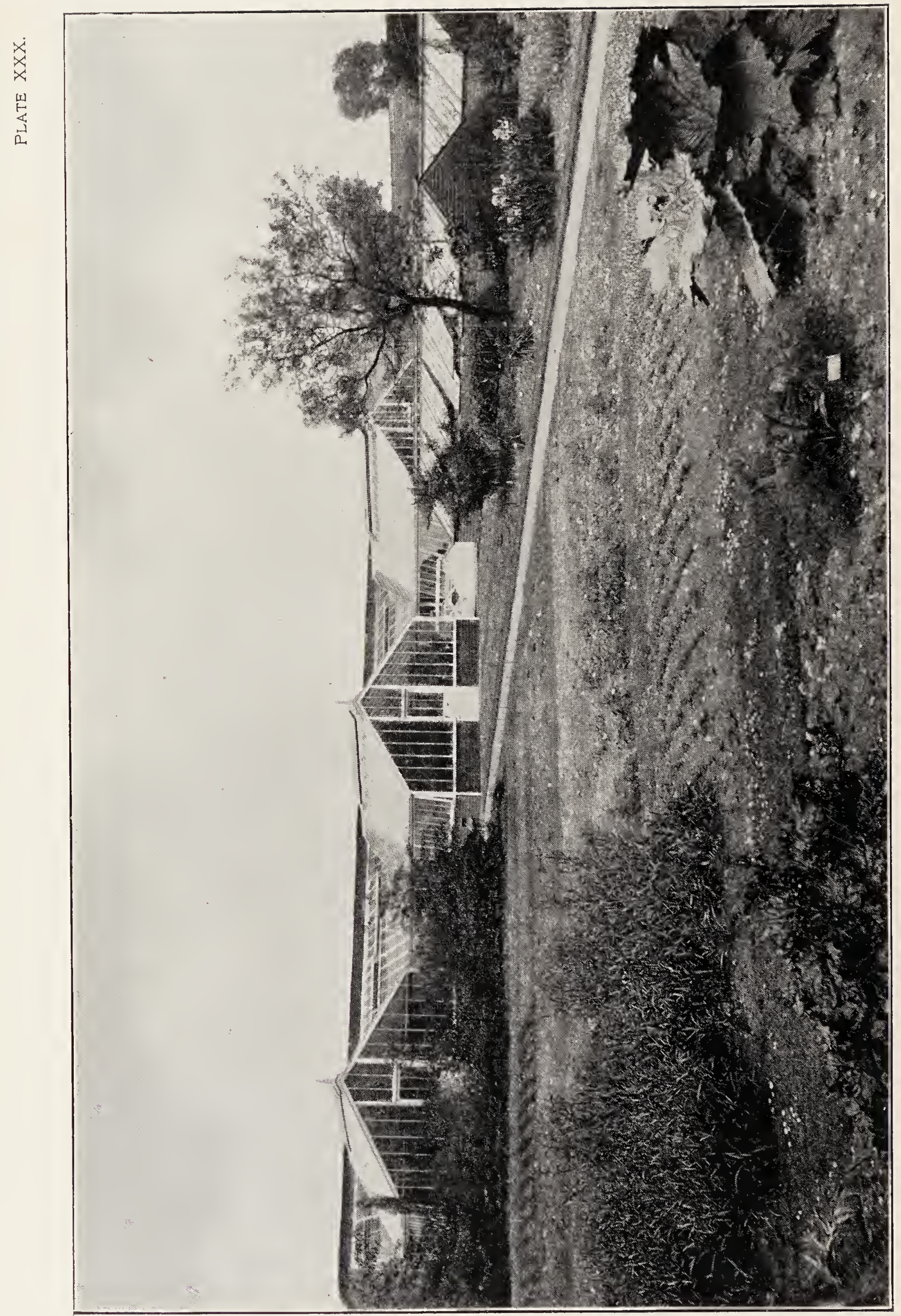

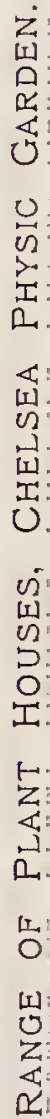


PLATE XXXI.

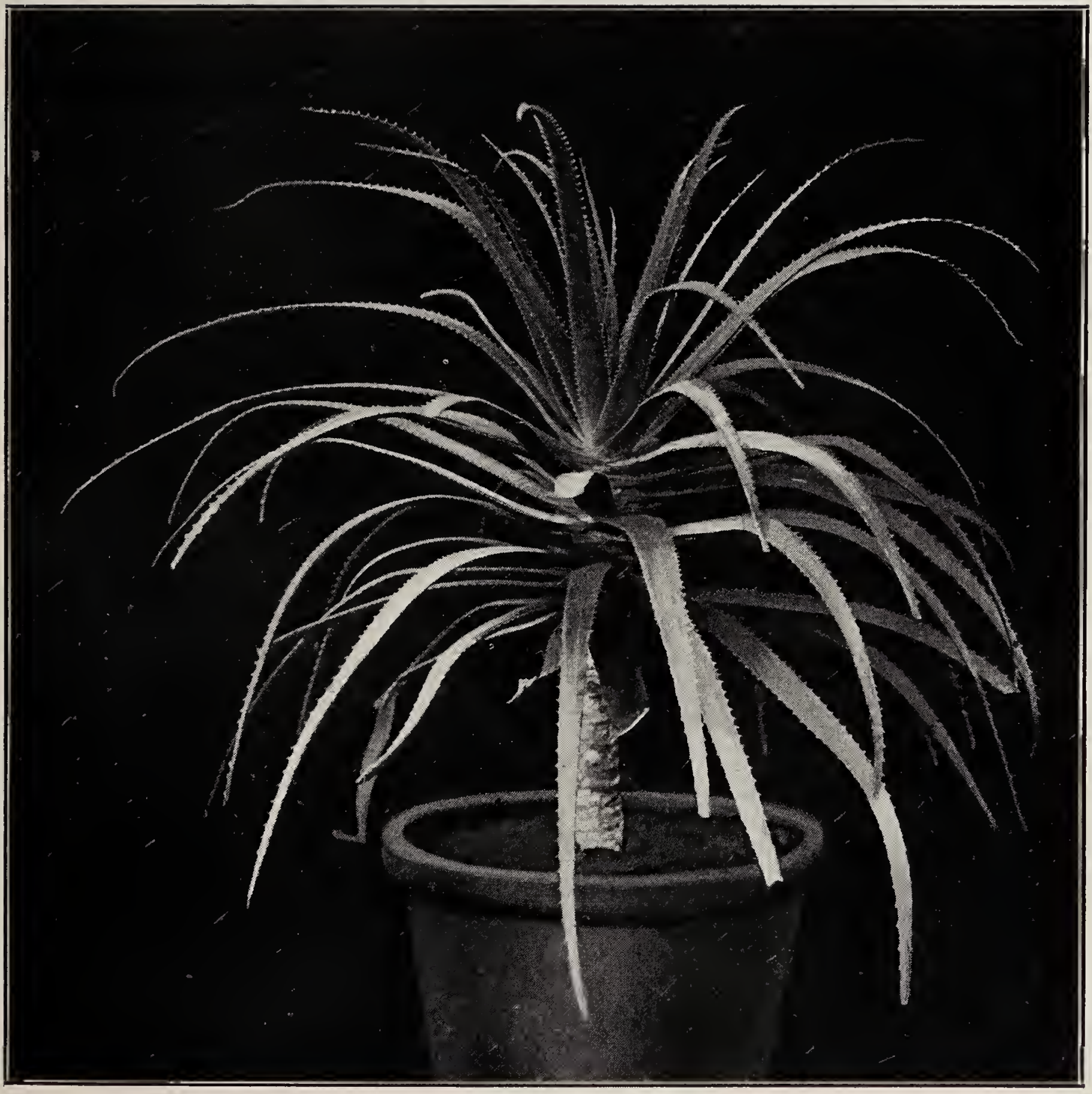

A Medicinal AloE,

Growing under glass in the Chelsea Physic Garden. 

The Laboratory Building, on which abuts the Curator's house, (see Plates VII and XXVI), is the distinctive feature of the Chelsea Physic Garden. It is a plain but substantial brick building, especially designed for modern educational needs under the superintendence of Professor Bretland Farmer. The main laboratory, 40 feet long by 25 wide, is on the ground floor, and opens into a small experimental greenhouse on the side remote from the main entrance (see Plate VII). It is admirably equipped for practical work, the benches being well lighted and provided with water and gas. In this laboratory there are two old oak presses which may have been used for storing Dale's herbarium, although there is nothing to indicate the fact. In addition to the main laboratory there are two small private laboratories at the gable end of the building, and between them is situated a dark room for photographic work. In one of these small laboratories, viz., that which adjoins the experimental greenhouse, there is a third oak press similar to those in the main laboratory. On the upper floor of the building there is, over the main entrance, a small room which is used by the Curator. This contains a small oak press which was manifestly adapted for storing herbarium specimens, and Isaac Rand's name is cut on the inner face of one of its doors. The main room on this floor, which corresponds in size and position with the main laboratory downstairs, is fitted up as a lecture hall, while there are two small rooms over the two small private laboratories and the dark room. These two rooms, and the wall abutting on the staircase and Curator's room, are fitted with book-cases which contain the library of the late Charles Darwin. Engravings of the garden at various periods are hung on the north wall of the lecture hall, Plates XXIII and XXV being reproduced from two of these.

At the end of May, I904, a tin tablet recording, in the following terms, the reconstitution of the garden, was placed on the west side of the entrance to the Laboratory Building:-

This Garden was established in the year 1673 by the Society of Apothecaries of London and was at first held on lease, but in I722 was conveyed by Sir Hans Sloane to the Society for the Encouragement of Botany.

The Garden was managed and maintained by the Apothecaries Society until the 2Ist January I899, when by a Scheme of the Charity Commissioners for England and Wales the Trustees of the London Parochial Charities were appointed to be the Trustees of this Garden in the place of the Society. Provision was then made for its management by a Committee appointed by the 
Trustees of the Garden, the Treasury, the Lord President of the Council, the Technical Education Board of the London County Council, the Royal Society, the Society of A pothecaries, the Royal College of Physicians, the Pharmaceutical Society, the Senate of the University of London, and the Representative of Sir Hans Sloane.

The old Lecture room and Curator's residence having been pulled down in I90o, the present buildings were erected on the same site and fornally opened on the $25^{\text {th }}$ July, Igo2, by the Rt. Hon. Earl Cadogan, K. G., a lineal descendant of Sir Hans Sloane.

Sir Joseph Savory, Bart.

\section{Chairman.} and

Sir Owen Roberts,

Vice-Chairman of the Trustees.
Wm. Hayes Fisher, IM.P.,

\section{Chairman}

and

Charles Algernon Whitmore, M.P.

Vice-Chairman Committee of

Management.

Algeruon Bertram. Baron Redesdale, Chairman of the Garden Committee.

H. Howard Batten, Clerk.

DECEMBER; I9O2.

The potting-house and the shed, to the east of the range of planthouses (see Plate XXVI), are to be included among the additions made in 1902, and the inscriptions on the pedestal of the Sloane Statue were also re-cut in that year.

The work of the Garden.-Medicinal plants, as such, no longer form a specialized feature of the Chelsea Physic Garden, inasmuch as the object aimed at by the body at present responsible for the management of the garden is educational in the wider sense, and the teaching of botany as a pure science has accordingly replaced the specialized study of drug-yielding plants. In associating laboratory work with the study of living plants in the botanic garden, Chelsea has followed the example set by some of our principal university centres. This association, as has already been indicated, is a relatively modern development, and the study of systematic botany which had, until recently, been overshadowed by the rise of laboratory teaching, is now encouraged, side-by-side with the latter.

The garden, as at present constituted, is intended for work, and not for recreation. This is made apparent by the following "Rules and Regulations as to Admission to the Garden, Lecture Room and Laboratory" drawn up by the Committee, and approved on November 20, $1902:-$

I. The purposes for which the Chelsea Physic Garden is maintained are :-

(I) To render assistance in the teaching of Botany;

(2) To provide material and opportunity for Botanical investigations. 
2. Admission to the Garden will be by ticket, issued by the Clerk to the Trustees, and any Teacher who desires to obtain access to the Garden should, in applying for such ticket, state the period for which it is required.

3. The Garden will be accessible to Teachers and Students on week-days from 9.30 a.m. to 5 p.m., except during the months of May, June and July, when it will not be closed until sunset.

4. Teachers holding tickets of admission will be allowed to introduce their Students to the Garden for purposes of study, but each Teacher will be held responsible for any damage that may be committed by his or her Students whilst in the Garden.

5. No plants grown in the open ground may be cut or uprooted without the consent of the Curator or some other responsible person directly connected with the Garden, but it is to be understood that permission to gather specimens for the purposes of study will be accorded whenever possible, but in no other circumstances.

6. No plant cultivated in the plant-houses may under any circumstances be cut except by the Curator or some other responsible person directly connected with the Garden.

7. Teachers requiring specimens for use in their own laboratories, on furnishing a list of desiderata, may be supplied with such specimens as can be spared from the Garden on reasonable notice being given to the Curator, and on the understanding that the applicant undertakes the trouble and charges of transfer of the specimens from the Garden to his or her Institution.

8. A ticket of admission to the Garden does not include access to the Laboratory Building. Any person desiring to make use of the Laboratory for purposes of research or otherwise should make special application to the Clerk to the Trustees. ${ }^{1}$

In the first report of the Committee of Management it is stated that, in drawing up these rules, "the Committee acted on the advice of Professor Farmer, who, before submitting his recommendations to the Committee, called a meeting of the Principals of the Polytechnics, which was well attended, the interests of at least 150 botanical students belonging to the Polytechnics being represented." The wisdom of this course has been demonstrated by the fact that the rules have, so far, proved quite satisfactory.

In conformity with the suggestion made to the Treasury Committee the needs of the students of botany in the Royal College of Science have been primarily considered. The Professor of Botany in that College has been appointed Scientific Advisor to the Committee of Management, and the laboratory is chiefly used by the

${ }^{1}$ I am authorized to state that orders for a visit to the Garden will be given by Mr. Howard Batten, if application be made to him in writing. Address: Mr. H. Howard Batten, clerk to the Trustees of the Chelsea Physic Garden, 3 Temple Gardens, Temple, London, E. C. 
students of the college, "working under the direct supervision of Professor Farmer; but occasional admission is granted to other students engaged in research work." The garden itself is used more freely by individual students or by classes in charge of their teachers. Another important branch of the work of the garden, as at Regent's Park, is the supply of cut specimens to many examining and teaching bodies, such as the University of London, the Royal College of Science, a few of the metropolitan medical schools, the various Polytechnics, etc.

The courses of advanced lectures in botany delivered in the lecture hall by specialists in various branches of that science must also be included among the educational features of the Chelsea Garden. These lectures are organized by the University of London, and have been, or will shortly be, given by the following: Professor J. Reynolds Green, Sir William Dyer, Dr. D. H. Scott, Professor J. Bretland Farmer, Professor F. W. Oliver, Dr. A. B. Rendle, Mr. A. D. Hall, Mr. V. H. Blackman, and Professor A. G. Tansley.

The activities of the garden, however, are not altogether limited to educational work. Mr. Francis Darwin has been continuously engaged in research at the Chelsea Garden, and one of the smaller laboratories on the upper floor of the Laboratory Building has been placed at his disposal, while the scientific library formerly belonging to his father, the late Charles Darwin, has been accommodated in the same building, as indicated above. Sir William Ramsay has also made experiments in the garden " in connection with the nutritive value of certain classes of manures," but the Chelsea Garden is not well adapted for this purpose, as it is only by persistent effort that plants can be made to thrive at all in an uncongenial atmosphere, such as that of London.

The system of seed exchange with other institutions which was inaugurated in 1682 is assiduously maintained, and a seed list is issued annually by the Curator. In the year I903-04, 872 packets of seeds were received aid 1,052 sent away, the recipients or donors comprising the following gardens: Kew, Dublin (Royal Botanical), Dublin (Trinity College), Cambridge, Oxford, Birmingham, Brunswick, Dresden, Erlangen, Kiel, Hamburg, Berlin, Greifswald, Ghent, Brussels, Groningen, Cracow, Görlitz, Innsbruck, Agram, Lemberg, Bucharest, Paris, Lyons (Medical), Lyons (Municipal), St. Petersburg, Palermo, La Mortola, Catania, Valencia, Madrid, Melbourne, Dunedin, and St. Louis (U. S. A.). 
[The following should be consulted for further details concerning the Chelsea Physic Garden :

Memoirs, Historical and Illustrative, of the Botanick Garden at Chelsea; belonging to the Society of Apothecaries of London, by Henry Field. London, I 820 .

The same, revised, corrected, and continued to I 878 , by R. H. Semple, M.D. London. I 878 .

The Physic Garden at Chelsea, by William Hales, Curator, in "The Garden" for August 2, I902, p. 79.

The Chelsea Physic Garden.-First Report of the Committee of Management. London. I905.

The History of the Society of Apothecaries of London, by C. R. B. Barrett, M.A. London. I905. This work contains many references to the Chelsea Pliysic Garden, culled from the minute books of the Society. It is, moreover, indispensable to those who wish to make themselves acquainted with the history of the Society. The general reader, however, will find it necessary to obtain some preliminary information respecting the development of the British apothecary before beginning Mr. Barrett's work, as there are, in the latter, references to various legislative enactments which will not be understood without some such assistance. For this purpose see "The Apothecary Ancient and Modern of the City of London," by George Corfe, M.D., London, I897, and the article "Apothecary" in the Encyclopædia Britannica, ninth edition, Vol. II, p. I9S.

No attempt has been made, in the present paper, to deal with biographical details. These are, nevertheless, of great interest, and will be found, for the most part, in Field and Semple or in the "Historical and Biographical Sketches of the Progress of Botany in England, from its origin to the Introduction of the Linncean System," by Richard Pulteney, M.D., F.R.S. In two volumes. London. 179o. The "Biographical Index of British and Irish Botanists," compiled by James Britten, F.L.S., and G. S. Boulger, F.L.S., F.G.S., London, IS93 (First Supplement, I899), should also be consulted.] 


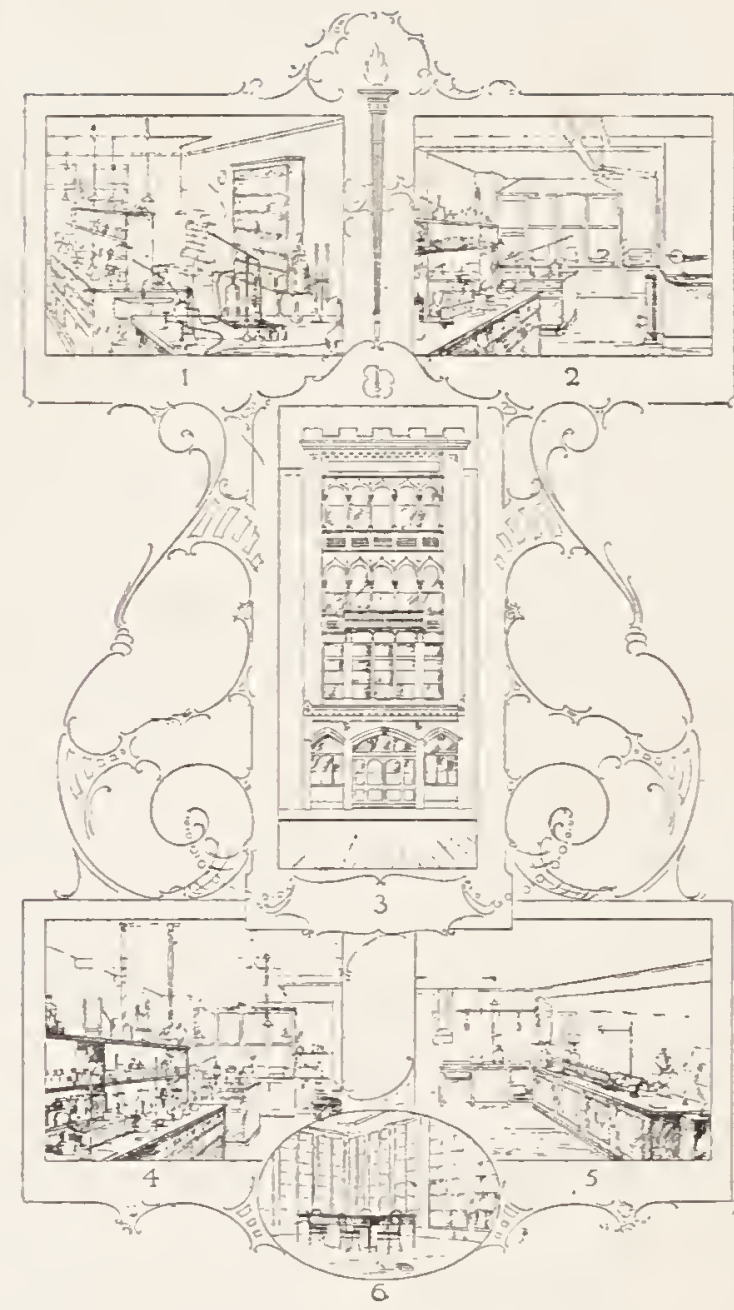



